Universidade de São Paulo

Faculdade de Filosofia Letras e Ciências Humanas

Departamento de Ciência Política

\title{
A Decadência Longe do Poder \\ Refundação e Crise do PFL
}

(Versão Corrigida - exemplar original se encontra disponível no

Centro de Apoio à Pesquisa Histórica da FfLCH) 
Ricardo Luiz Mendes Ribeiro

A Decadência Longe do Poder

Refundação e Crise do PFL

(Versão Corrigida - exemplar original se encontra disponível no Centro de Apoio à Pesquisa Histórica da FFLCH)

\author{
Dissertação apresentada à Faculdade de Filosofia Letras e \\ Ciências Humanas da Universidade de São Paulo para obtenção \\ do título de Mestre em Ciência Política
}

Orientador: Prof. Dr. André Singer

São Paulo, 2011 
Às minhas meninas, Maria Pia, Luiza e Olivia 


\section{Agradecimentos}

Desejo, em primeiro lugar, afirmar que a minha tardia incursão acadêmica pela Ciência Política foi muito proveitosa. Independentemente do resultado desta dissertação, a jornada valeu a pena. Graças em grande parte aos professores do Departamento de Ciência Política da Faculdade de Filosofia, Letra e Ciências Humanas da USP com os quais tive a oportunidade e o prazer de aprender bastante sobre este tema fascinante que é a política. Todos eles honraram a tradição de seriedade, pensamento crítico e dedicação ao ensino e à pesquisa que notabiliza a FFLCH. Aprendi muito também com os meus colegas de mestrado e doutorado, dentro e fora das aulas. Quero agradecer especialmente a Sérgio Simoni Júnior que, de maneira magnânima, dividiu comigo pensamentos, discussões, dicas e bibliografia sobre partidos políticos, tema ao qual ele também se dedicou em sua dissertação de mestrado.

Não posso deixar de mencionar a enorme contribuição que os professores Leandro Piquet Carneiro e Matthew Taylor deram a este trabalho. Ambos participaram de minha banca de qualificação. Suas críticas e sugestões me ajudaram a dar prumo à pesquisa e me mostraram o quanto de trabalho ainda tinha pela frente.

Agradeço também aos colegas da labuta diária, que me incentivaram a encarar o desafio de voltar aos bancos escolares e toleraram as minhas ausências e saídas abruptas no meio do expediente. Sou especialmente grato a Marcos da Costa Fantinatti pelo auxílio no tratamento estatístico dos dados.

Também sou grato aos políticos do PFL/DEM e aos professores Antônio Lavareda e Antonio Paim que tiveram a paciência de me atender. Seus valiosos depoimentos muito me ajudaram na composição desta dissertação. Ao professor Lavareda, um agradecimento especial por ter me cedido o relatório da $\mathrm{MCl}$ sobre o PFL.

Registro ainda que, sem o apoio, a compreensão e o amor de minha mulher e filhas, eu teria ficado pelo meio deste e de outros caminhos.

Por fim, agradeço, acima de tudo, ao professor André Singer, meu orientador e também um grande incentivador de meu trabalho. Além de ter dado valiosas sugestões para a pesquisa, sempre foi muito franco e crítico na avaliação dos meus escritos. Revelou-se ainda uma pessoa extremamente generosa, não apenas comigo, mas com todos os alunos com os quais o vi interagir. Não poderia exigir mais de um orientador. 


\section{Resumo}

Esta dissertação tem como objetivo analisar o processo de refundação do Partido da Frente Liberal (PFL), que resultou na troca de comando do partido e na substituição da denominação anterior da legenda por Democratas (DEM), em março de 2007. Assumimos a hipótese de que a transferência do PFL para a oposição a partir de 2003, fato inédito na história do partido e que foi decorrente da chegada do PT ao poder federal, foi o evento determinante para a decisão de seus dirigentes de tentar dar nova imagem e identidade ao PFL. Argumentamos também que a refundação teve como objetivo reposicionar o PFL no mercado político eleitoral brasileiro de modo a que pudesse atrair o apoio da classe média urbana localizada nas cidades de médio e grande porte. Mostramos que a passagem para a oposição desencadeou o enfraquecimento do PFL. Dois movimentos conjugados provocaram o retraimento do partido: 1) a transferência de políticos pefelistas para legendas aliadas ao governo Lula; 2) o mau desempenho eleitoral na região Nordeste, reduto tradicional do PFL em sua fase governista e que passou a ser progressivamente dominado por partidos que apoiavam a administração petista. Por fim, com base nos resultados das eleições municipais de 2000 , 2004 e 2008, apresentamos dados e testes estatísticos que sustentam a ideia de que os municípios menos desenvolvidos, menos populosos, localizados no Nordeste e cujas economias são mais dependentes do setor público possuem viés governista. Isto é, nessas localidades, mais do que no restante do país, o poder local tende a se alinhar com o poder federal. Tal tendência parece fornecer uma boa explicação para o retraimento do PFL nos municípios com as características acima definidas.

Palavras chave: Partido Político, PFL, Sistema Partidário, Eleições Municipais, Governismo. 


\begin{abstract}
This dissertation aims to analyze the re-foundation process of the Partido da Frente Liberal (PFL), which resulted in the change of command of the party and the replacement of the previous name of the legend by Democrats (DEM) in March 2007. We assume the hypothesis that the transfer of the PFL for the opposition since 2003, unprecedented in the history of the party and that was determined by the arrival of PT in the federal government, was the crucial event to the decision of party leaders to try to give new image and identity to the PFL. We argue also that the re-foundation aimed to reposition the PFL in Brazilian electoral political market in order to attract the support of the urban middle class located in large and medium-sized cities. We show that the transition to the opposition led to the weakening of the PFL. Two movements together caused the retreat of the party: 1) the transfer of PFL politicians to parties allied to Lula's administration, 2) the poor electoral performance in the Northeast, traditional stronghold of the PFL during the time it was in the government and that was progressively dominated by parties which supported PT administration. Finally, dealing with the results of municipal elections in 2000, 2004 and 2008, we present data and statistical tests that support the idea that less developed municipalities, few populated, located in the Northeast region and whose economies are more dependent on public sector have a progovernment bias. That is, in these locations, more than in the rest of the country, local government tends to align with the federal government. This trend seems to provide a good explanation for the withdrawal of the PFL in municipalities with the characteristics specified above.
\end{abstract}

Key words: Political Party, PFL, Party System, Local Elections, Governism. 


\section{Lista de Gráficos e Tabelas}

\section{GRÁFI COS}

Gráfico 1 - Bancadas do PFL-DEM na Câmara e no Senado.............................. 6

Gráfico 2 - Desempenho do PFL-DEM nas eleições municipais............................

Gráfico 3 - Número de prefeitos de capitais eleitos pelo PFL-DEM $\ldots \ldots \ldots \ldots \ldots \ldots \ldots \ldots \ldots \ldots 7$

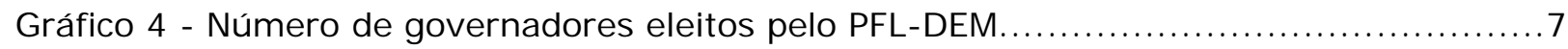

Gráfico III.1.a - Número de deputados que deixaram o PFL na legislatura de $2003 \ldots . . . . . . .79$

Gráfico III.1.b - Número de deputados que deixaram o PFL na legislatura de $2007 \ldots \ldots \ldots . . .79$

TABELAS

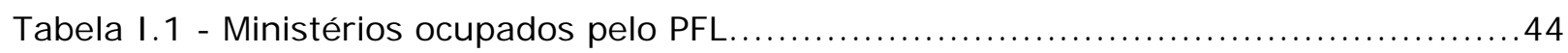

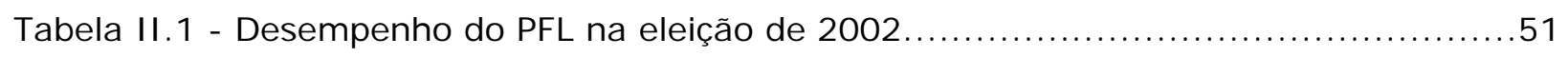

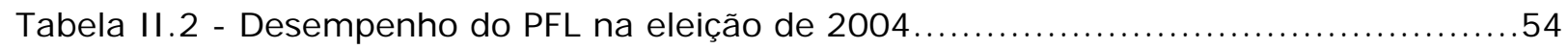

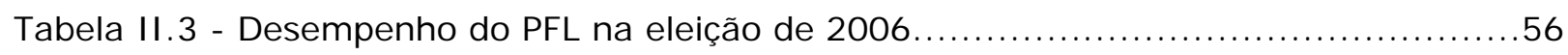

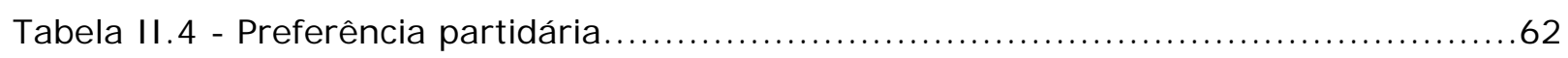

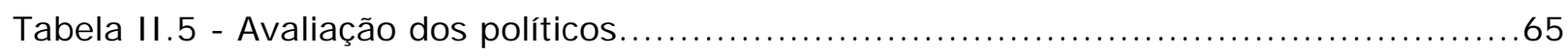

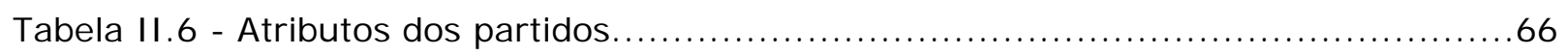

Tabela III.1 - Deputados federais eleitos pelo PFL-DEM, por região.....................74

Tabela III.2 - Vereadores e prefeitos eleitos pelo PFL-DEM, por região....................75

Tabela III.3 - Destino dos deputados federais que deixaram o PFL....................... 81

Tabela III.4 - Deputados federais eleitos e que deixaram o PFL, por estado..................82

Tabela III.5 - Resultado das eleições municipais, geral e por segmentos...................88

Tabela III.6 - Desempenho relativo dos partidos nas eleições municipais....................89

Tabela III.7 - Prefeitos eleitos por partidos governistas e não governistas no Nordeste.....92

Tabela III.8 - Testes de média, partidos governistas e não governistas....................93

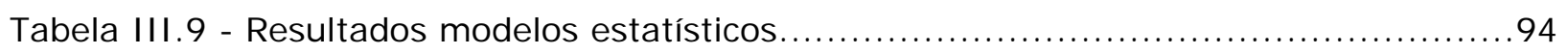




\section{Índice}

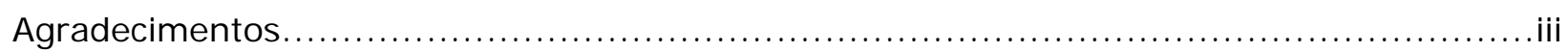

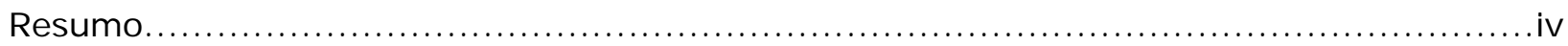

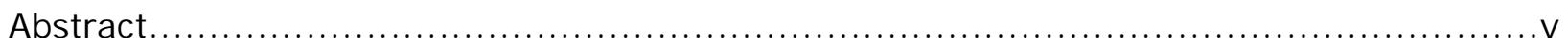

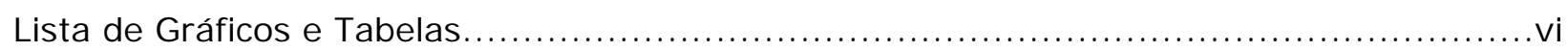

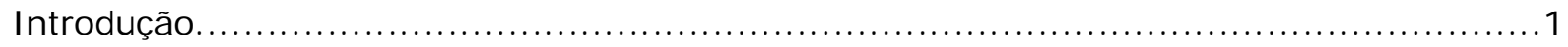

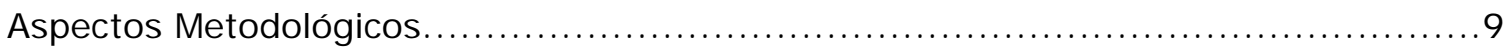

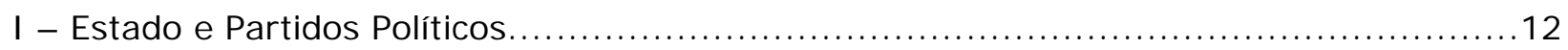

I.1 - Dos Partidos de Quadros aos Partidos Cartel.................................... 13

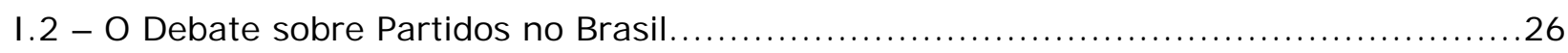

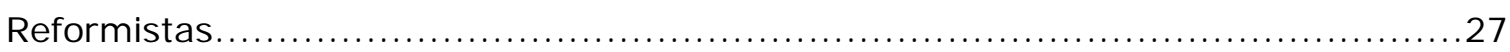

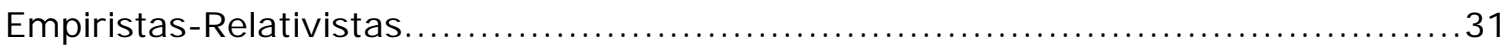

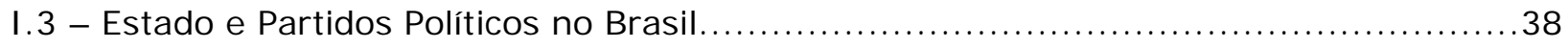

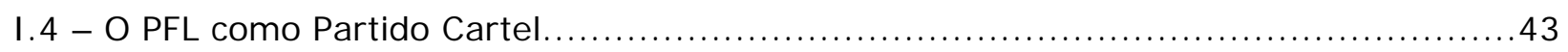

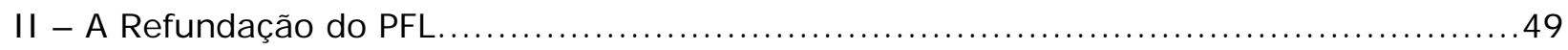

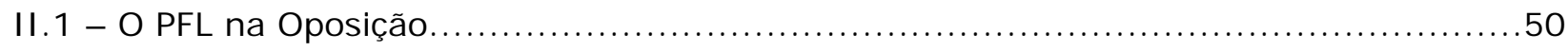

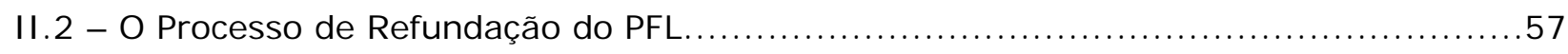

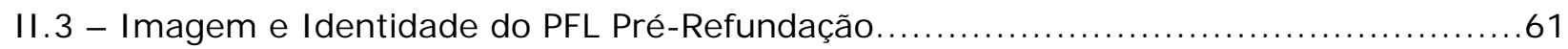

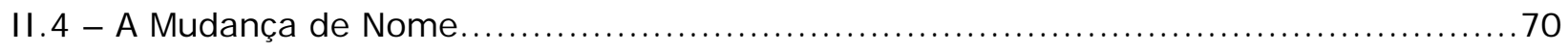

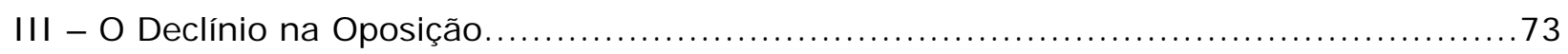

III.1 - O Enfraquecimento Decorrente da Migração Partidária..............................78

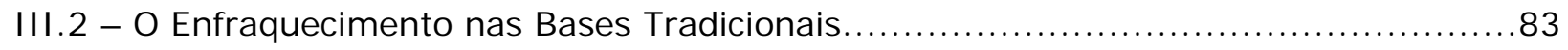

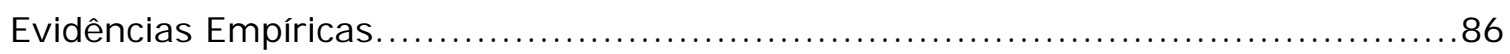

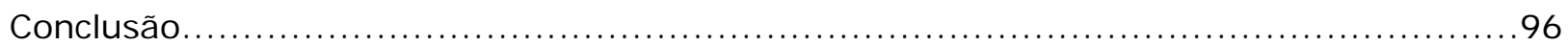

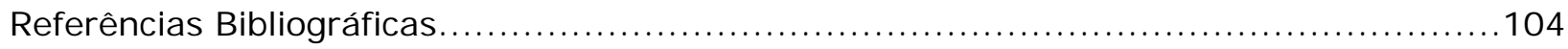

Apêndice 1 - Documentos e Textos Programáticos do PFL/DEM..........................111

Apêndice 2 - Ranking do IDH dos Estados Brasileiros.................................. 112

Apêndice 3 - Relação entre Transferências da União e Receita dos Estados.................113

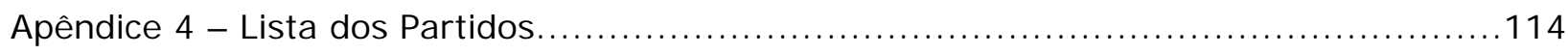




\section{NTRODUÇÃO}

O objetivo desta dissertação é analisar o processo de refundação do PFL, o qual resultou na troca do nome do partido para Democratas, ou DEM, como ficou mais conhecido. $O$ surgimento do DEM foi também o ato final do PFL, partido criado em 1985 por um grupo de dissidentes do antigo PDS que decidiram apoiar a eleição de Tancredo Neves no Colégio Eleitoral.

Dada a importância do PFL no período de restabelecimento e de maturação do regime democrático no Brasil, o seu fim também seria, por si só, um acontecimento relevante na história política do país e, como tal, merecedor da atenção da ciência política brasileira. Mas há outro fator que faz com que a refundação do PFL se torne ainda mais interessante. Conforme tentaremos argumentar ao longo da dissertação, a ascensão do PT ao poder nacional e a consequente ida do PFL para a oposição foram a causa determinante do processo que os dirigentes do partido nomearam de "refundação". Assim, investigar o fim do PFL é tratar também, mesmo que marginalmente, de outro evento importante na política brasileira: a chegada do PT ao poder.

Nossa hipótese principal é que a ida do PFL para a oposição foi o evento determinante para a decisão de refundar o partido, ou seja, de levar adiante a tentativa de deter o encolhimento da legenda, de reposicioná-la no mercado eleitoral brasileiro e de lhe dar nova identidade perante o eleitor, capacitando-a a atrair o apoio de nova clientela eleitoral, formada pela população de renda média dos aglomerados urbanos de médio e grande porte. Mostraremos também que essa novidade na história pefelista, foi crucial para provocar o declínio do partido.

Apresentaremos evidências de que a passagem para a oposição enfraqueceu o partido de duas maneiras interconectadas. Primeiro, provocou a saída de diversos parlamentares eleitos originalmente pelo PFL e que buscaram abrigo em legendas mais próximas ao governo Lula. Depois, prejudicou o desempenho eleitoral do partido em seus redutos tradicionais, ou seja, nos chamados grotões do Nordeste, os quais foram progressivamente ocupados por partidos ligados ao governo petista.

Diversos fatores qualificam o PFL como objeto de pesquisa acadêmica. A favor de um estudo acadêmico sobre o PFL há, em primeiro lugar, a inegável relevância do partido na história política recente do país. Do ponto de vista histórico, três acontecimentos sustentam tal afirmação. 
O primeiro, e mais importante evento a destacar, é a eleição de Tancredo Neves no Colégio Eleitoral em 15 de janeiro de 1985, causa e consequência da criação do PFL. ${ }^{1} A$ eleição de Tancredo Neves foi um marco decisivo no processo de redemocratização do país, apesar de sua morte ter colocado o país nas mãos de José Sarney, que pouco tempo antes presidia o PDS, partido de sustentação do regime militar. O inesperado desfecho da sucessão de João Batista Figueiredo, aliado ao fato de a eleição de Tancredo ter sido indireta, corroboram a avaliação, ilustrada por essa declaração de Mainwaring, Meneguello e Power (2000: 29), de que, "considerando o declínio de sua legitimidade e a espiral do colapso econômico que marcaram a ditadura no início dos anos 80, dificilmente o resultado da transição de 85 poderia ter sido mais favorável à direita".

A validade do argumento expresso pela citação acima não elide o fato de a eleição de Tancredo Neves ter sido uma ocorrência fundamental no longo e tortuoso caminho do restabelecimento da democracia no país. Tancredo não teria sido eleito se um grupo de dissidentes do PDS liderados pelo vice-presidente Aureliano Chaves não tivesse rompido com o governo e com o próprio partido. Os dissidentes do PDS deram 176 votos a Tancredo (15 senadores, 110 deputados federais e 51 deputados estaduais) ${ }^{2}$, que recebeu no total 480 votos, contra 180 do ex-governador paulista, Paulo Maluf. Ou seja, se não houvesse a dissidência do PDS, se os 176 dissidentes tivessem apoiado o candidato governista, Maluf receberia 356 votos contra 304 de Tancredo e sucederia o General J oão Batista Figueiredo na Presidência da República. Do ponto de vista histórico, este foi o momento culminante da legenda, ou melhor, do grupo político que fundou o PFL, pois o partido ainda não havia sido formalmente criado, o que só ocorreu em 24 de janeiro de 1985.

O anti-malufismo, a percepção de que o governo militar estava com os dias contados e que a redemocratização era inevitável, a disputa entre os civis que apoiaram o regime militar e a falta de habilidade política do presidente João Batista Figueiredo são razões comumente apontadas para que Aureliano Chaves, José Sarney, Marco Maciel, Jorge Bornhausen, José Agripino Maia, Guilherme Palmeira, Roberto Magalhães, Luiz Gonzaga Mota, entre outros, se afastassem do governo e do PDS para apoiar Tancredo

Para Lavareda (1985) o segundo fator foi mais relevante. De acordo com ele, Maluf se tornou o símbolo negativo, a personificação de um regime que não dispunha mais de respaldo da maioria da sociedade e da opinião pública. Já o ex-senador Jorge Bornhausen, em entrevista para esta dissertação, disse que o grupo de deputados e senadores dissidentes do PDS "anteviam um processo de grandes problemas sociais e de grande repulsa quando um nome [Maluf] que não agradava a sociedade foi se alinhavando". (entrevista ao autor). Queiroz

\footnotetext{
${ }^{1}$ Para uma boa e sintética descrição dos eventos que levaram ao surgimento do PFL, ver Cantanhêde (2001: 16 -32).

${ }^{2}$ Cantanhêde (2001: 32).
} 
(2009), por outro lado, tem uma interpretação interessante para a reação ao malufismo dentro do PDS. De acordo com ele, o problema foi que Maluf

\begin{abstract}
"no afã de assegurar sua escolha como candidato do PDS para presidente em convenção na qual concorreria com outros candidatos qualificados (Marco Maciel, Andreazza e Aureliano) subverteu os comandos estaduais, estabelecendo conflitos explícitos com as lideranças tradicionais do partido. Para muitos, a vitória de Maluf representaria mudanças no eixo de comando do partido nos Estados, razão principal do empenho de derrotá-lo. Por isso foi possível convergir interesses antípodas em muitos Estados, como em Minas (Tancredo e Aureliano), em Pernambuco (Marco Maciel e Roberto Magalhães/Marcos Freire e Jarbas Vasconcelos), na Bahia (Antônio Carlos Magalhães e Waldir Pires), em Santa Catarina (Jorge Bornhausen e Luiz Henrique) e outros tantos". (Queiroz 2009: 4).
\end{abstract}

Para Mainwaring, Meneguello e Power (2000: 29), "a divisão do PDS e a fundação do PFL deram aos antigos defensores da ditadura a oportunidade de se desligarem publicamente de um regime autoritário cada vez mais impopular".

Já a descrição de cunho jornalístico feita por Dimenstein et al (1985) destaca os erros e os desencontros cometidos pelos dirigentes do PDS e pelo presidente J oão Batista Figueiredo na condução da escolha do candidato governista. A partir do relato dos jornalistas, depreendese que o desfecho da sucessão do último presidente militar poderia ter sido bastante diferente, pois, durante o processo de discussões e negociações sobre a sucessão presidencial levado adiante pelas forças governistas da época, a candidatura de Paulo Maluf esteve em vários momentos próxima de não se viabilizar. E, sem Maluf, provavelmente, não teria havido a dissidência que originou o PFL e, consequentemente, nem a eleição de Tancredo Neves.

A Assembléia Constituinte foi o segundo acontecimento histórico importante no qual o PFL teve atuação decisiva. O PFL possuía a segunda maior bancada da Assembléia Constituinte, com 118 deputados, $24,2 \%$ do total e 15 senadores (20,8\%). Os pefelistas foram os principais líderes do bloco pluripartidário que ficou conhecido como "Centrão". Formado na reta final dos trabalhos da Constituinte, o bloco agregou as forças conservadoras de vários partidos e se tornou majoritário na votação de temas importantes. Se o Centrão não tivesse existido, muito provavelmente, a Constituição aprovada teria sido outra. Seria mais estatista e intervencionista no campo econômico. Foi na articulação do Centrão que o deputado Luís Eduardo Magalhães começou a se destacar na Câmara dos Deputados.

Luís Eduardo Magalhães também teve papel de relevo no terceiro momento histórico importante na história do país e do PFL: o apoio às reformas de cunho liberal e pró-mercado implementadas durante o governo Fernando Henrique Cardoso. Embora o PMDB também tenha participado da base de sustentação de Fernando Henrique Cardoso, o PFL foi o seu 
parceiro primordial. Não apenas porque o apoiou desde quando se lançou candidato, mas principalmente porque, programaticamente, estava alinhado à agenda de reformas de Fernando Henrique Cardoso. Como destaca Roma (2002), a aproximação entre os tucanos e o PFL, que gerou fortes resistências entre setores do PSDB, não se deveu apenas à necessidade de fortalecer eleitoralmente a candidatura Fernando Henrique Cardoso. Decorreu também da afinidade em relação às reformas que Fernando Henrique estava disposto a levar adiante e para as quais precisava de apoio no Congresso.

Provavelmente, a partir da situação gerada pelo sucesso quase imediato do Plano Real, Fernando Henrique, ao contrário de Tancredo Neves, seria eleito mesmo sem a aliança com o PFL. Porém, para além da questão eleitoral existia o alinhamento de ideias entre o PFL e o grupo tucano mais próximo a Fernando Henrique Cardoso. Ambos estavam convictos de que era necessário acelerar o processo de privatização, aumentar o grau de abertura da economia brasileira, quebrar os monopólios públicos do petróleo e das telecomunicações e reformar a previdência social. Ou seja, foi uma aliança programática e não meramente eleitoral. E o PFL foi o partido mais fiel ao governo Fernando Henrique Cardoso, mais até que o próprio PSDB. ${ }^{3}$ Sem o PFL, Fernando Henrique Cardoso teria tido mais dificuldade para aprovar o seu programa de reformas.

Em entrevista que nos foi concedida, Saulo Queiroz, enfatizou que Fernando Henrique Cardoso tinha exata noção da importância da aliança com o PFL para a sustentação política ao Plano Real e para a aprovação de suas reformas no Congresso. Segundo o relato de Queiroz, após o fracasso da candidatura presidencial de Mário Covas em 1989 e o impeachment de Fernando Collor de Mello, nem o PSDB nem o PFL possuíam um nome para apresentar como candidato a presidente em 1994.

“Éramos naquele momento um país destruído politicamente, depois do governo
Collor, do impeachment, da CPI do Orçamento, aquela zona no país. As pessoas
começaram a descontar politicamente no PSDB. Então apareceu o Fernando
[Henrique Cardoso]. Ele tinha uma chance, quando ele assumiu o Ministério da
Fazenda. Quem conhecia bem o Fernando sabia. Brilho pessoal, respeitabilidade.
Ele só não tinha era vontade de fazer política. Detestava isso. Era um horror.
Falo isso de cadeira, porque eu era do PSDB naquela época. Mas ele entrou na
Fazenda e vinte dias depois já estávamos falando da candidatura dele. Para o
PFL foi uma tábua de salvação. Tinha uma eleição para se tocar. Nós sentamos
para conversar em janeiro [1994]. Nós falamos com o Fernando o seguinte:
você não tem a menor chance de ter um bom caminho sem o PFL. Você precisa
do PFL para fazer uma campanha sem grandes problemas. Principalmente, você

${ }^{3}$ Ver Figueiredo e Limongi (1998), cujos dados a respeito das votações do projeto de reforma da previdência proposto pelo presidente Fernando Henrique Cardoso mostram que o PFL deu mais apoio ao projeto do que o PSDB. Ver também Nicolau (2000). 
precisa do PFL para aprovar os fundamentos do teu plano. Na hora que você fizer o acordo com o PFL, você aprova o plano no Congresso. Ele falou, 'eu topo"'. (entrevista ao autor)

Queiroz, que, apesar de ter se transferido para o PSDB, mantinha boas relações com o PFL, partido que ajudou a fundar, foi então encarregado de iniciar os contatos com dirigentes pefelistas a fim de formar a coligação para disputar a eleição. Em poucos dias, o acordo entre o PFL e Fernando Henrique foi fechado e o então ministro da Fazenda garantiu aos dirigentes pefelistas que, ao contrário do que ocorrera em 1989 com Mário Covas, sustentaria a aliança, a despeito da esperada oposição que isso despertaria em setores do PSDB.

A fala de Queiroz deixa claro que, além de coerente do ponto de vista programático, a aliança com o PSDB também fazia muito sentido politicamente para o PFL. Deu-lhe a chance concreta de voltar a ter posição central no governo federal após o desgaste causado pelo apoio dado pelas lideranças mais expressivas do PFL - Antônio Carlos Magalhães e Jorge Bornhausen - a Fernando Collor de Mello até quase os momentos derradeiros de seu governo. A associação com o PSDB garantiu ao partido mais oito anos de proximidade com o poder federal.

Outro entrevistado, o ex-ministro Gustavo Krause, atribuiu ao PFL papel de destaque tanto na transição democrática quanto no processo de estabilização macroeconômica. Krause afirmou que "nós [o Brasil] tivemos duas grandes conquistas: a democratização e a estabilização econômica e o partido [PFL] foi muito importante para ambas. Foi importante na transição democrática e foi muito importante no processo de estabilização monetária e de aprovação de outras reformas que vieram posteriormente." (entrevista ao autor)

Além da participação nos eventos históricos destacados acima, há números contundentes que expressam a importância do PFL-DEM na política brasileira após a redemocratização.

Praticamente desde que foi fundado, o PFL se tornou um dos maiores partidos do Congresso, posição que disputou com o PMDB, na maior parte do tempo. O gráfico abaixo mostra a evolução das bancadas do PFL na Câmara dos Deputados e no Senado desde 1986. 


\section{Gráfico 1 - Bancadas do PFL-DEM na Câmara e no Senado}

( $\%$ do total de cadeiras)*

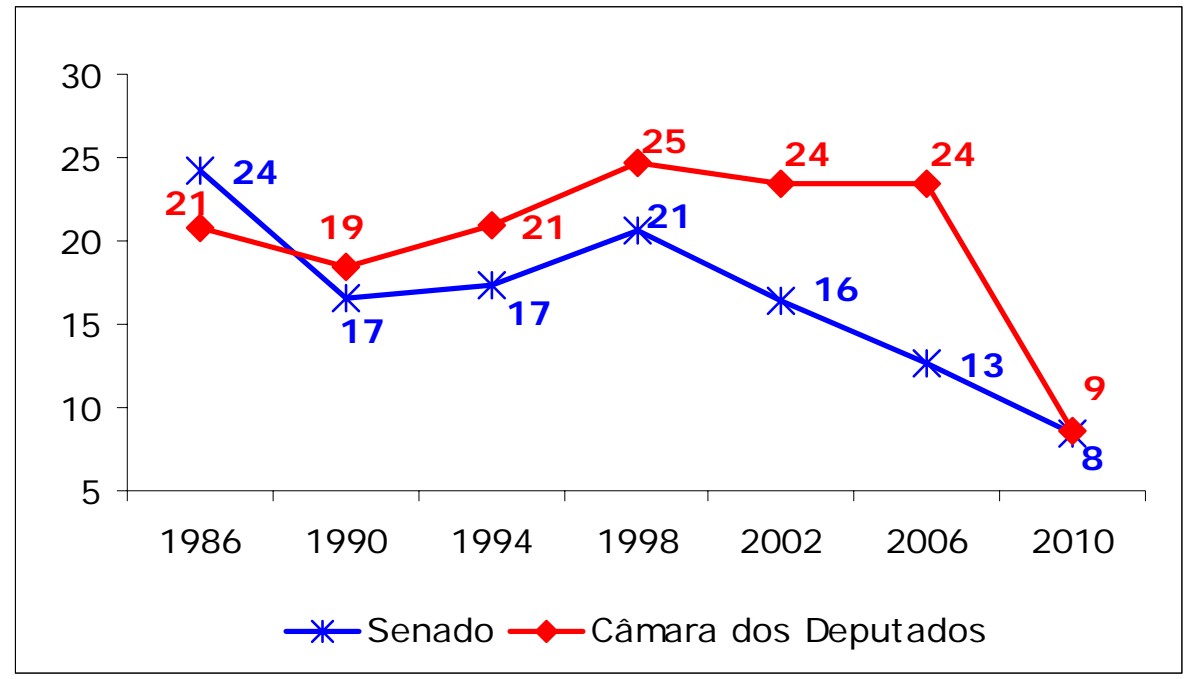

Fonte: TSE, Câmara dos Deputados e Senado.

* Bancadas eleitas

O PFL foi o partido majoritário na Câmara dos Deputados entre 1998 e 2002, quando sua bancada variou entre 110 a 98 deputados. A Câmara dos Deputados foi presidida por pefelistas por duas vezes. Inocêncio de Oliveira, em 1994 e 1995, e Luís Eduardo Magalhães, em 1995 e 1996. No Senado, o PFL alternou com o PMDB a posição de maior bancada entre 1998 e 2002. O PFL também ocupou a presidência do Senado com Antônio Carlos Magalhães, entre 1997 e 2001.

\section{Gráfico 2 - Desempenho do PFL-DEM nas eleições municipais}

( $\%$ do total de prefeitos eleitos)

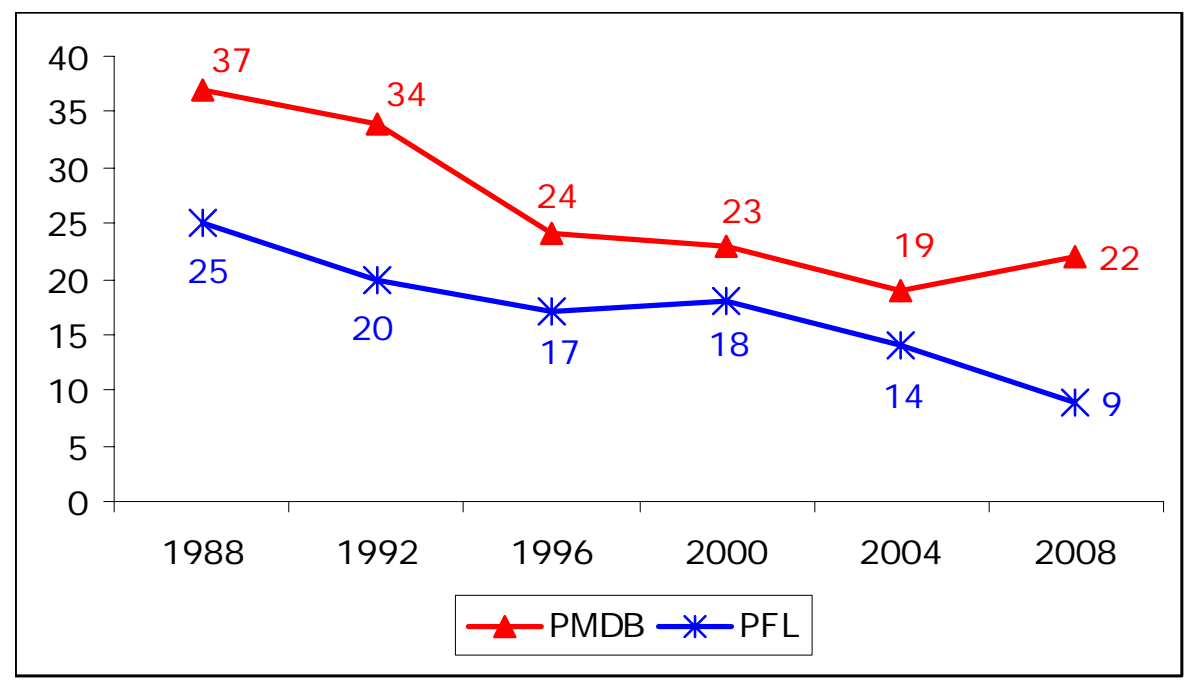

Fonte: Nicolau (2010) e TSE

No plano municipal, ilustrado pelo Gráfico 2, o PFL foi durante vários anos o segundo maior partido em termos de número de prefeitos e de vereadores, perdendo apenas para 0 
PMDB. Na eleição municipal de 2004, foi ultrapassado pelo PSDB, que elegeu 871 prefeitos, contra 789 do PFL. Em 2008, já como DEM, o número de prefeitos eleitos pelo partido caiu ainda mais. Foram apenas 498. Ficou atrás do PMDB (1215 prefeitos), PSDB (790), PT (563) e PP (551).

O PFL governou ainda várias capitais, inclusive as duas maiores cidades do país, Rio de Janeiro, com César Maia, e São Paulo, com Gilberto Kassab.

\section{Gráfico 3 - Número de prefeitos de capitais eleitos pelo PFL-DEM}

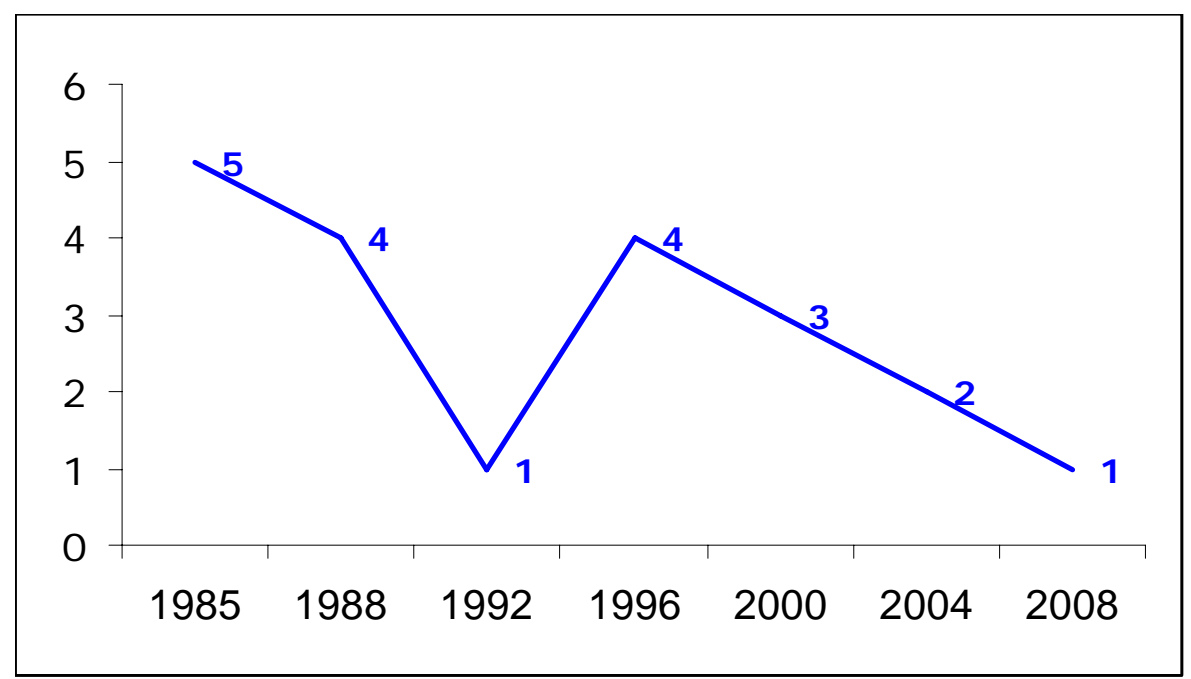

Fonte: Nicolau (2010).

Além disso, elegeu 23 governadores ao longo de sua história. Desses, 13 foram eleitos em estados do Nordeste ( $56 \%$ do total), 5 no Norte, 3 no Sul e 2 no Centro Oeste. O PFL nunca conseguiu eleger um governador no Sudeste. Entre os estados, os que mais vezes foram governados por pefelistas foram Bahia e Maranhão, ambos em 4 oportunidades.

\section{Gráfico 4: Número de governadores eleitos pelo PFL-DEM}

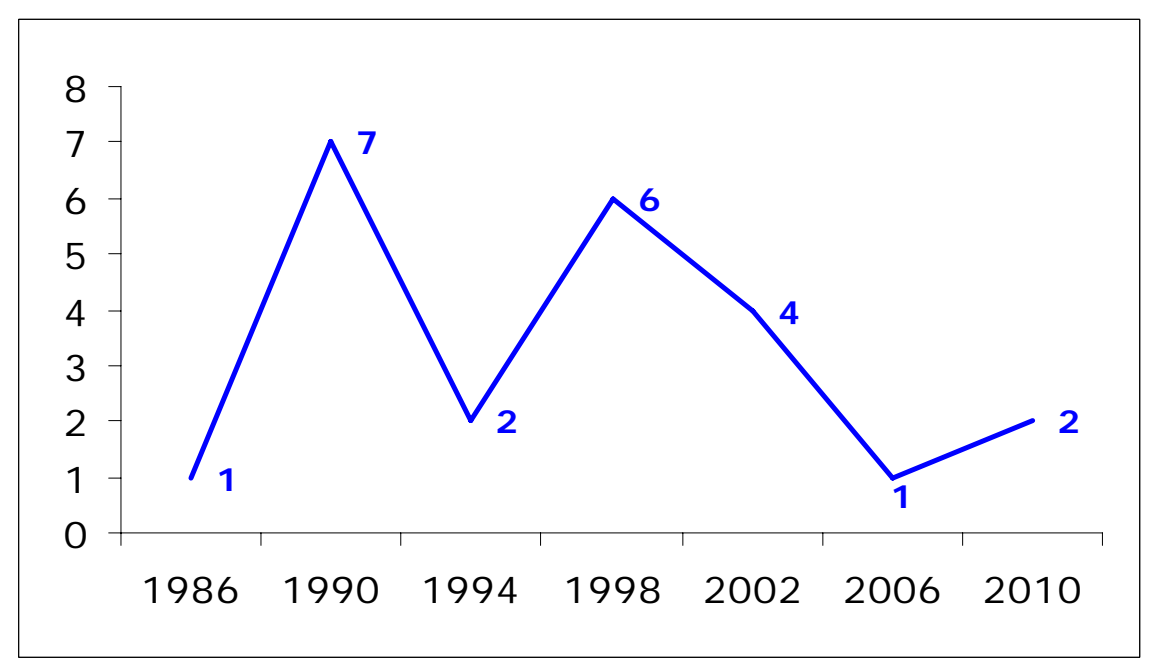

Fonte: TSE 
O PFL participou ainda dos ministérios de todos os governos pós regime militar, à exceção de Lula. Por fim, ocupou a vice-presidência durante oitos anos (1995 a 2002), com Marco Maciel.

São números que atestam a força do PFL-DEM e que o qualificam como um dos principais partidos do atual ciclo democrático brasileiro.

Apesar disso, o PFL foi pouco estudado pela ciência política brasileira. E esta é a segunda justificativa para a escolha do PFL como objeto da dissertação. Aliás, existem poucos trabalhos sobre partidos conservadores no Brasil. ${ }^{4}$ Os partidos de esquerda costumam receber mais atenção dos pesquisadores brasileiros. Este trabalho também pretende ajudar a cobrir essa lacuna.

Entre os partidos considerados conservadores, a UDN foi objeto de estudo de Benevides (1981), enquanto Hipólito (1985) e Lippi (1973) analisaram a trajetória do PSD. Ainda com foco no período pós-getulista e pré-militar, Sampaio (1982) abordou o PSP e o ademarismo. Mainwaring, Meneguello e Power (2000), por sua vez, são autores de um livro que trata de maneira conjunta os partidos conservadores brasileiros contemporâneos. Mais recentemente, Almeida (2004) estudou a origem e a trajetória do PPB, em dissertação de mestrado.

Quanto ao PFL, foi tema de um artigo de Lavareda (1985), no qual ele analisa a participação de alguns governadores nordestinos na dissidência aberta no PDS e que resultou na criação do PFL; de um livro de Cantanhêde (2001), onde a história da legenda é contada de maneira resumida; de uma tese de doutorado - Campos (2002) -, que examina o PFL de Pernambuco; e de uma dissertação de mestrado, na qual Tarouco (1999) trata da trajetória do partido até o final dos anos 90, momento no qual o partido atingiu o apogeu do ponto de vista de sua força parlamentar e não havia ainda passado pela experiência de fazer oposição ao governo federal. Tarouco (2002) também publicou um artigo sobre o PFL, que é um desdobramento de sua dissertação de mestrado. Nenhum texto acadêmico a respeito do DEM foi encontrado.

A terceira justificativa para o estudo do PFL é que a análise deste partido pode servir de ponto de partida para discussões mais amplas a respeito da política e do sistema partidário

\footnotetext{
${ }^{4}$ Citando pesquisa feita por ele no banco de dados bibliográficos Data Índice, que cobre 70 revistas científicas brasileiras na área de ciências sociais, Leal (2005: 15) constatou que em janeiro de 2003 havia 17 artigos em consulta sobre o PT. Curiosamente, em segundo lugar aparecia o PCB com 15 registros, um partido pouco relevante no período pós ditadura militar. Almeida (2004: 2) também ressalta a parca literatura a respeito dos partidos conservadores ou de direita no Brasil vis a vis os de esquerda. A preferência por estudar partidos de esquerda não parece estar restrita ao Brasil. Wolinetz (2002: 2070), por exemplo, diz que "we [political scientists] pay more attention to parties of the left than parties of the right”. Power (2000:5) diz praticamente o mesmo a respeito da ciência política na América Latina.
} 
brasileiro. Para esta dissertação, a questão de fundo que perpassa a análise é a relação entre Estado e partidos políticos e a força do governismo no Brasil.

Na sequência desta Introdução, apresentaremos, no primeiro capítulo, uma abordagem teórica que, a nosso juízo, se adequa bem às questões envolvidas na passagem do PFL para o DEM. O modelo básico que utilizaremos é o de partido cartel proposto por Katz e Mair (1995). Faremos também uma revisão da literatura brasileira a respeito do sistema partidário nacional e trataremos da discussão sobre a relação Estado e partidos políticos no Brasil, com especial ênfase na contribuição de Maria do Carmo Campelo de Souza para a compreensão desse tema.

No segundo capítulo, descreveremos o processo de refundação do PFL, a conjuntura política do momento, o desenrolar de eventos partidários que resultaram no surgimento do DEM e os motivos que levaram seus dirigentes a optar por esse caminho. Além disso, analisaremos a pesquisa feita pela empresa $\mathrm{MCl}$ que deu subsídios à decisão de refundar o PFL.

No terceiro capítulo, apresentaremos evidências empíricas para sustentar a hipótese de que a ida do PFL para a oposição foi o evento decisivo para a refundação do partido e também para o seu acelerado enfraquecimento. Para tanto, utilizaremos dois conjuntos de dados: o primeiro, sobre a migração partidária, e o segundo sobre as eleições municipais de 2000, 2004 e 2008. Optamos pelas eleições municipais porque elas nos permitem relacionar o desempenho eleitoral do partido com variáveis geográficas, populacionais e sócio-econômicas, o que não é possível fazer a partir das eleições nacionais, visto que a última vez que o PFL apresentou candidato à Presidência da República foi em 1989. A eleição de 2000 será tomada como representativa do perfil do partido quando ainda fazia parte do governo federal. A de 2004, que parece ter sido uma eleição de transição, de adaptação do sistema de poder local à chegada do PT à Presidência da República, foi realizada com o PFL já na oposição, mas antes da refundação. 2008 foi a primeira pós-refundação. Foi também o primeiro teste do DEM nas urnas.

Por fim, na Conclusão, sintetizaremos nossas análises e descobertas, entremeando-as com a discussão teórica que fizemos no Capítulo 1 e com algumas considerações a respeito do atual cenário político brasileiro.

\section{ASPECTOS METODOLÓGI COS}

Do ponto de vista metodológico, esta dissertação é um estudo de caso a respeito do sistema partidário brasileiro. Como todo estudo de caso, tem como objeto de análise um assunto ou evento específico. Nosso objeto é a refundação do PFL, evento a partir do qual procuramos obter subsídios para o entendimento mais amplo a respeito de alguns aspectos 
relacionados à evolução do sistema partidário brasileiro nos últimos anos, particularmente desde 2003, quando o PT chegou ao poder federal. Procuramos, assim, ir além da descrição factual da refundação do PFL, a qual, no entanto, está bastante presente na dissertação, especialmente no Capítulo 2.

Para o desenvolvimento da dissertação, além do material bibliográfico, utilizamos como fonte de dados e informações: 1) entrevistas com dirigentes partidários do PFL e cientistas políticos relacionados à legenda; 2) documentos oficiais do partido; 3) textos de discussão programática produzidos pelo partido ou por políticos e militantes ligados a ele $^{5}$; 4) pesquisa feita pela empresa $\mathrm{MCl}$ sobre a imagem do PFL e que forneceu subsídios para o processo de refundação e de troca de nome do partido.

As entrevistas foram de tipo aberta. Todas elas foram feitas por mim. Foram gravadas e posteriormente transcritas. Duraram em média uma hora e tiveram como foco principal o processo de refundação do partido. As pessoas entrevistas foram:

1) Jorge Bornhausen, ex-senador e ex-presidente do PFL. A entrevista foi realizada no dia 14/05/2009, em São Paulo;

2) Marco Maciel, ex-vice-presidente da República e ex-senador pelo PFL/DEM. A entrevista foi realizada no dia 17/11/2009, em Brasília;

3) Saulo Queiroz, ex-deputado federal, ex-secretário geral e ex-tesoureiro do PFL/DEM. Entrevista realizada no dia 17/11/2009, em Brasília;

4) José Agripino Maia, senador pelo PFL/DEM. Entrevista realizada no dia 18/11/2009, em Brasília;

5) José Carlos Aleluia, ex-deputado federal pelo PFL/DEM. Entrevista realizada no dia 18/11/2009, em Brasília;

6) Gustavo Krause, ex-deputado e ex-ministro (governos Itamar Franco e Fernando Henrique Cardoso) pelo PFL. Entrevista realizada no dia 11/12/2009, em Recife;

7) Antônio Lavareda, cientista político. Foi o principal responsável pela pesquisa da $\mathrm{MCl}$ sobre a imagem e o reposicionamento do PFL descrita no Capítulo 2 desta dissertação. Entrevista realizada no dia 11/12/2009, em Recife;

\footnotetext{
${ }^{5}$ O Apêndice 1 desta dissertação traz a lista com os documentos e os textos partidários que foram utilizados neste trabalho.
} 
Os testemunhos dos atores diretamente ligados aos partidos carregam, naturalmente, uma carga de subjetividade inerente aos laços e aos interesses que os conectam à história e às atividades partidárias. Portanto, devem ser aproveitados com certa prudência. Contudo, além de serem em si mesmo historicamente importantes, pois revelam o ponto de vista de personagens relevantes na vida partidária, frequentemente oferecem ao pesquisador pistas e elementos úteis para a análise e entendimento dos partidos.

Por essa razão, é um recurso bastante utilizado em estudos sobre partidos. Foram largamente empregadas, por exemplo, nos trabalhos de Kinzo (1988), sobre o PMDB; de Sampaio (1982), sobre o PSP; de Hippolito (1985), sobre o PSD; e de Benevides (1981), sobre a UDN. Na literatura internacional, Gunther e Hopkin (2002) também lançam mão desse recurso para subsidiar suas análises a respeito da UCD (Unión de Centro Democrático) espanhola.

Nesta dissertação, as entrevistas aparecem ao longo de quase todo o texto e serviram para esclarecer questões relacionadas à história do PFL, para suscitar pontos de discussão ou para auxiliar na sustentação de análises e conclusões.

Por fim, além do material bibliográfico, dos textos e relatórios produzidos pelo PFL, da pesquisa da $\mathrm{MCl}$ e das entrevistas, utilizamos também os resultados das eleições municipais de 2000, 2004 e 2008. Tais resultados foram trabalhados em conjunto com dados relativos ao desenvolvimento dos municípios (IDH), tamanho (população), localização regional e importância do setor público na economia municipal. Todas essas informações serviram de base para a análise descritiva e estatística (modelos probit) dos efeitos da passagem do PFL para a oposição sobre o desempenho do partido nas eleições municipais. Serviram também como elemento para testar a hipótese de que municípios com certas características possuem um viés governista. Isto é, de que o poder local em municípios pequenos, pouco desenvolvidos, dependentes do setor público e localizados no Nordeste, tende a se alinhar com o grupo político que está no poder em âmbito federal. Mais detalhes a respeito da metodologia empregada na análise estatística desses dados serão fornecidos no Capítulo 3. 


\section{I - ESTADO E PARTIDOS POLÍTICOS}

“É fundamental fazermos uma coisa que não fizemos ainda: transformar um partido de quadros em um partido de base.

Temos bons quadros. Mas, mais do que quadros, temos que ter bases".

Marco Maciel (entrevista ao autor)

A frase do senador do ex-senador Marco Maciel (PE) na epígrafe acima alude a um anseio comum entre os dirigentes do antigo PFL. Um dos objetivos do processo de refundação do PFL foi justamente transformar um partido essencialmente de quadros em um partido de base. Na entrevista, Marco Maciel não deixou claro o que entende por "partido de base", mas, transpondo-se a frase para o plano da teoria política, é imediata a associação entre a declaração do ex-senador e as categorias "partido de quadros" e "partido de massas" propostas por Duverger em seu clássico trabalho sobre partidos políticos.

Segundo a definição consagrada por Duverger, partidos de massas são aqueles que se sustentam no apoio de militantes fieis ao partido, que ele denomina de "adeptos", os quais, além de lhe fornecerem estofo ideológico, são também a principal fonte de financiamento para as atividades partidárias. Ou seja, a existência de uma base, isto é, de um conjunto amplo de eleitores e apoiadores que estão ligados entre si por laços sociais e de classe, compartilham interesses e ideologias, e se sentem representados por uma determinada agremiação política, é um elemento essencial para classificar um partido como sendo "de massas". Isto é, quando Marco Maciel diz que o PFL - ou o DEM - precisa de uma base, no fundo, sob a lente da teoria política, está afirmando que o objetivo do PFL era se transformar em um partido de massas.

Considerando-se as origens e as características do PFL, parece um objetivo um tanto desprovido de sentido. Tampouco combina com a gênese dos partidos de massa, que historicamente tiveram como base os movimentos trabalhistas do final do século XIX e começo do século XX. O modelo foi posteriormente adotado, com relativo sucesso, por partidos de perfil conservador. Mas, como diz o próprio Duverger, pelo menos em seus primórdios, adaptava-se melhor a agremiações de origem socialista:

\footnotetext{
"a distinção entre partidos de quadros e os partidos de massa corresponde quase que do mesmo modo à da direita e da esquerda, dos partidos 'burgueses' e dos partidos 'proletários'. Nem financeiramente, nem politicamente, a direita burguesa tinha necessidade de enquadrar as massas: ela possuía seus arrecadadores de fundos, suas pessoas gradas, suas elites. Julgava suficiente a sua cultura política. Igualmente, até o fascismo, as tentativas de criação de partidos de massas conservadores geralmente fracassaram. A repugnância instintiva da burguesia ao enquadramento e à ação coletiva desempenhava
} 
igualmente seu papel nesse setor, da mesma forma que a tendência inversa da classe operária favoreceu o caráter maciço dos partidos socialistas". (Duverger 1970: 103)

A aspiração de Maciel e dos dirigentes do PFL-DEM é, contudo, compreensível, tendo em vista que o modelo ideal de partido consagrado no plano do senso comum continua a ser o do "partido de massas". A dissonância entre essa imagem ideal e a maneira concreta como a maioria dos partidos contemporâneos se organiza e atua é uma das razões aventadas por alguns autores ${ }^{6}$ para explicar a alegada crise que afeta as agremiações partidárias de maneira generalizada em quase todo o mundo.

Porém, os partidos de massa já não são o modelo de partido político predominante nas democracias representativas. Na verdade - e essa avaliação é praticamente consensual entre os estudiosos do assunto - foram substituídos por modelos de partido mais consentâneos às democracias contemporâneas. Katz e Mair (2009: 760) chegam a afirmar veementemente que "the mass party is dead".

De todo modo, embora manifeste uma ambição pouco exequível, a frase de Marco Maciel nos serve de ponto partida para a discussão teórica acerca da passagem do PFL para o DEM. O pilar central da discussão teórica será a tipificação proposta por Katz e Mair (1995): partido cartel. Argumentaremos que esse tipo de partido, além de mais adequado para caracterizar o PFL, também é capaz de ajudar a explicar as dificuldades do partido depois das vitórias de Lula em 2002 e 2006.

Além do partido cartel, utilizaremos também esquema elaborado por Wolinetz (2002) para discutir a refundação do PFL, movimento que, nos termos propostos por Wolinetz, corresponde, segundo nossa interpretação, à tentativa de transformar um partido essencialmente office-seeking em um partido vote seeking e até mesmo policy seeking.

Neste capítulo, abordaremos ainda a discussão brasileira acerca da institucionalização e do grau de solidez do nosso sistema partidário. Trataremos também da relação entre Estado e partidos no Brasil, destacando a contribuição de Maria do Carmo Campello de Souza para a compreensão dessa questão.

\section{I.1 - Dos partidos de quadros aos partidos cartel}

Segundo Gunther e Montero (2002), o estudo dos partidos políticos é uma das subáreas mais profícuas e mais antigas da ciência política. Os primeiros trabalhos remontam ao início do século passado. Ostrogorski, (1962 [1902]), Michels (1962 [1911]) e Weber (1978

\footnotetext{
${ }^{6}$ Ver Daalder (2002) e Linz (2002).
} 
[1922]), são os autores destacados por Gunther e Montero (2002) como precursores dos estudos sobre partidos.

Além de antiga, a literatura sobre partidos é vasta. Gunther e Montero (2002) citam levantamento feito por Caramani e Hugs (1998), segundo o qual, desde 1945, mais de 11.500 livros, artigos e monografias foram escritos a respeito desse assunto apenas na Europa.

Contudo, a despeito da vasta produção acadêmica, Gunther e Montero (Ibidem: 119) admitem que os esforços para construir uma teoria geral sobre os partidos não foram especialmente bem sucedidos. Em outras sub-áreas da ciência política foi possível construir "broader consensus regarding concepts, terminology, and operational indicators which underpin research in some other related subfields of political science" (Ibidem: 223), mas não no caso dos estudos sobre partidos políticos. O aspecto mais frágil dos trabalhos sobre os partidos, afirmam eles, seria justamente a conexão entre a teoria e os trabalhos empíricos. Não foi possível derivar uma teria geral sobre os partidos a partir da pesquisa empírica e, por outro lado, a teoria não ofereceu sólidas hipóteses passíveis de serem empiricamente testadas. É uma avaliação que, ironicamente, foi também feita por dois dos mais eminentes estudiosos dos partidos: Duverger (1954) e Sartori (1976).

Ou seja, de acordo com Gunther e Montero (2002), apesar da amplidão e da antiguidade dessa sub-área, os estudos sobre os partidos políticos ainda não foram capazes de construir uma base sólida e relativamente consensual de conceitos e de descobertas empíricas que possam nortear o trabalho de um pesquisador contemporâneo interessado no assunto. É o pior dos mundos para tal pesquisador, que corre sério risco de se perder na vastidão da literatura por conta da falta de pilares reconhecidamente sólidos a partir dos quais pode construir o seu trabalho.

No nosso caso, optamos por tomar as contribuições de Katz e Mair (1995, 1996, 2002 e 2009) como a base teórica principal para a nossa reflexão sobre a transformação do PFL em DEM. Três razões justificam a escolha. Primeiro, as categorias teóricas criadas por eles (partido cartel, partido on the ground, in the central office e in the public office) tiveram grande impacto na discussão teórica mais recente sobre partidos além de terem estimulado trabalhos de cunho empírico ${ }^{7}$. Segundo, os conceitos de partido cartel e de partido in the public office nos parecem bastante apropriados para caracterizar o PFL. Terceiro, esses conceitos foram utilizados com sucesso por Tarouco (1999) para estudar a fase áurea do PFL. Resgatá-los, agora em um contexto certamente mais negativo para o partido, nos permitirá dialogar com o trabalho de Tarouco, que, no registro acadêmico, é, salvo engano, a pesquisa mais ampla e bem acabada sobre o PFL já realizada até o momento.

\footnotetext{
${ }^{7}$ Ver Kwak (2003) e Scarrow (2006).
} 
As contribuições de Katz e Mair se inserem no esforço empreendido por vários autores ${ }^{8}$ para tentar caracterizar os partidos na chamada fase do pós catchallism do sistema partidário. A periodização da evolução dos partidos proposta por Katz e Mair (2002) é a seguinte: partidos de quadros, partidos de massa, partidos catch-all e partidos cartel. Essa sequência, pelo menos até o catch-all, é usual na literatura sobre partidos.

Antes de caracterizar cada um desses tipos de partidos, é importante salientar que, primeiro, são modelos ideais que não correspondem exatamente aos partidos existentes; e, segundo, a história que essa periodização relata é fundamentalmente a dos partidos europeus e, em segundo plano, dos partidos americanos. Os partidos das chamadas novas democracias na América Latina e na Ásia, que constituíram a "terceira onda da democracia", não são objeto central de estudo dessa literatura.

Os partidos de quadros foram tipicamente a organização predominante no final do século XIX e início do século XX. Segundo Duverger, uma distinção importante entre partidos de quadros e de massas é que os primeiros não têm adeptos, isto é simpatizantes vinculados ao partido e que, além de servirem como fonte para o recrutamento da elite que concorrerá nas eleições e ocupará cargos públicos, são normalmente os principais responsáveis pela sua sustentação financeira. No partido de quadros, o financiamento partidário, usando o termo aplicado por Duverger, é do tipo "capitalista". São os membros endinheirados do partido que Ihe repassam os recursos necessários à sua sobrevivência. No fundo, o partido de quadros não passa de uma reunião de pessoas ilustres. Como diz Duverger sobre esse tipo de partido:

\footnotetext{
“Trata-se de reunir pessoas ilustres, para preparar eleições, conduzi-las e manter contato com os candidatos. Pessoas influentes, de início, cujo nome, prestígio ou brilho servirão de caução ao candidato e lhe granjearão votos; a seguir, pessoas ilustres como técnicos, que conhecem a arte de manejar os eleitores e de organizar uma campanha; enfim, pessoas notáveis financeiramente, que contribuem com o fator essencial: dinheiro".(Duverger, 1970: 103)
}

Tais características deixam evidente que o partido de quadros, em sua conformação tradicional, estava despreparado para sobreviver à ampliação do sufrágio universal, processo que se intensificou no começo do século passado. Conforme Duverger, "em seu conjunto, o desenvolvimento dos partidos parece associado ao da democracia, isto é, à extensão do sufrágio popular e das prerrogativas parlamentares". (I bidem: 20)

Como já salientamos, um elemento essencial dos partidos de massa é a existência de adeptos, que, nas palavras de Duverger, constituem "a própria matéria do partido, a

\footnotetext{
${ }^{8}$ Ver, por exemplo, Panebianco (1988).
} 
substância de sua ação" (I bidem: 99). Os adeptos, que poderíamos chamar também de simpatizantes ou, quando têm uma relação mais ativa com o partido, de militantes, são responsáveis pela sustentação financeira da agremiação. São também eleitores cativos do partido. Compartilham afinidades ideológicas e fazem parte de um mesmo grupo social. Invariavelmente, a comunicação entre o partido e seus adeptos era feita por intermédio de jornais partidários, responsáveis por disseminar a opinião e o posicionamento da legenda para os seus simpatizantes. É um tipo de organização que, em seus primórdios, combinava melhor com partidos socialistas ou de origem trabalhista. De acordo com Duverger, o primeiro partido de massas da burguesia foi o Partido Nacional Socialista que, conforme dados apresentados pelo autor, tinha cerca de 800 mil adeptos em 1932.

O partido de massas tornou-se paradigmático do modelo ideal de partido que se cristalizou no imaginário da opinião pública. Ao senso comum, partido deveria ser uma organização dotada de coerência ideológica e amparada por uma base relativamente estável de filiados e simpatizantes que se identificam com o partido em função de afinidade ideológicas ou de interesses. ${ }^{9} \mathrm{O}$ conceito de que partido de massas é o modelo ideal de partido tornou-se também forte na teoria política. Como dizem Katz e Mair,

\begin{abstract}
"it was widely assumed then that most parties could be understood as mass parties or as the more modern catch-all variant of mass parties. This was not only the key empirical model, it had become the key normative model: for many scholars this was what parties should be like, how they should be organized and behave, and to the extent that they did not meet the standards of a mass party, then they were, essentialy by definition somehow weak or failing" (2009: 754).
\end{abstract}

Depreende-se da leitura de Duverger que ele também considerava o partido de massas como o modelo ideal de partido e previa que essa estrutura se tornaria predominante nas democracias desenvolvidas. Serviria de exemplo até para os partidos norte-americanos, considerados "atrasados" por ele. ${ }^{10} \mathrm{E}$, mais do que isso, segundo Duverger, os partidos que não se organizassem segundo esse modelo estariam fadados a perecer.

Contudo, não foi o que ocorreu. A partir dos anos 60, o partido de massas começa a perder vitalidade. Assim como a ampliação do sufrágio universal foi determinante para o fortalecimento dos partidos de massa e o encolhimento dos partidos de quadros, a ascensão social da classe trabalhadora e do operariado foi a mudança fundamental que pavimentou o

\footnotetext{
${ }^{9}$ Linz (2002), por exemplo, atribui a opinião negativa a respeito dos partidos, detectada em pesquisas de opinião em vários países, ao predomínio de uma visão idealizada e irrealista a respeito dos partidos que remete ao partido de massas, o qual não corresponde mais ao modelo predominante na atualidade na maioria das democracias representativas.

${ }^{10}$ Para uma crítica à tese de que o partido de massas é a etapa final do processo evolutivo dos partidos, ver Mair (1997: 93-94).
} 
caminho para os partidos catch-all, termo cunhado por Kirckheimer (1966) ${ }^{11}$. Nesse sentido, como afirma Mair (1997:101), pode-se dizer que o sucesso da agenda dos partidos de massa encarregou-se de mudar o ambiente sócio econômico no qual esse tipo de organização havia vicejado.

O processo de substituição do partido de massas pelo catch-all é assim descrito por Kirchheimer:

\begin{abstract}
“The mass integration party, product of an age with harder class lines and more sharply protruding denominational structures, is transforming itself into a catchall 'people's' party. Abandoning attempts at the intellectual and moral encadrement of the masses, it is turning more fully to the electoral scene, trying to exchange effectiveness in depth for a wider audience and more immediate electoral success". (1966: 184)
\end{abstract}

Como a própria denominação desse modelo de partido já indica, a característica fundamental do catch-all é a tentativa de conquistar o voto de amplas parcelas do eleitorado, independentemente de divisões ideológicas ou de classe, diferenciação, alias, que a ascensão social e econômica da classe trabalhadora tratou de atenuar. Além de borrar as fronteiras ideológicas, o aburguesamento da classe trabalhadora e a consolidação do welfare state homogeneizaram as demandas políticas dos diferentes segmentos do eleitorado. Tornou-se possível, assim, a um partido defender políticas e plataformas simpáticas a amplas parcelas do eleitorado. Nesse ambiente, a concorrência entre os partidos também contribuiu para uniformizar as propostas partidárias. Consequentemente, como a diferenciação programática e ideológica entre os partidos tornou-se menos evidente, a disputa eleitoral transformou-se em um embate mais personalista e menos um confronto entre plataformas e políticas públicas alternativas.

O desenvolvimento dos meios de comunicação de massa foi outra novidade, que possibilitou a transformação dos partidos de massa em catch-all. A disseminação do rádio e, principalmente, da televisão, deu aos candidatos canais apropriados para alcançar amplas parcelas do eleitorado.

Em termos de organização partidária, os filiados e adeptos perderam importância no modelo catch-all. Não são mais eles que determinam a estratégia política e eleitoral do partido. A direção do partido deixou de ser um agente dos adeptos da legenda. O poder decisório passou a ser exercido principalmente pelos detentores de cargos públicos eletivos. A importância dos filiados e simpatizantes para o financiamento partido também decresceu em

\footnotetext{
${ }^{11}$ O electoral professional party de Panebianco (1988) e o modern cadre party de Koole (1994), são variantes do catchall party.
} 
função da fragilização dos laços que uniam o partido a seus simpatizantes e filiados. Em decorrência disso, os partidos passaram a buscar outras fontes de financiamento, movimento potencializado pelo aumento substancial dos custos das campanhas eleitorais.

O conjunto dessas mudanças resultou no que muitos autores chamam de "americanização" da política européia (Mair 1994: 18) e, ao mesmo tempo, desencadeou uma discussão, ainda ativa nos dias de hoje, a respeito da crise dos partidos políticos.

Na verdade, a perda de vitalidade das ideologias políticas, a burocratização dos partidos, a personalização da política, a debilidade dos partidos são alguns elementos frequentemente citados para caracterizar não apenas a crise dos partidos, mas também da própria democracia representativa. A percepção da crise seria tão arraigada que Lavalle et al (2006) dizem até que no pensamento político produzido no último quarto do século passado tornou-se comum aplicar-se o termo crise a quase tudo relacionado à política. Assim, estaria ocorrendo a crise dos partidos, da própria política, da democracia e da representação.

Manin (1997), por exemplo, corrobora a tese da crise dos partidos, que, depreende-se da leitura de seu livro, seria grave e, provavelmente, irreversível, ao menos do ponto de vista da representação política, questão central de sua análise. Na periodização da democracia representativa proposta por Manin, os partidos foram a agência política central durante o que ele chama de "democracia partidária", período que se estendeu do final do século XIX ao final da década de 60. Antes disso, predominava o que ele chama de "democracia parlamentar". A passagem da democracia parlamentar para a democracia partidária é marcada justamente pela ascensão dos partidos políticos como principais agentes de conexão entre a sociedade e o Estado. E a decadência dos partidos, por sua vez, é um dos elementos que caracterizam a "democracia de audiência", denominação utilizada por Manin para se referir ao regime democrático na atualidade. Nota-se que é quase imediata a correspondência entre esses modelos de democracia descritos por Manin e a tipologia dos partidos que apresentamos anteriormente. O partido típico da democracia parlamentar foi o partido de quadros, sucedido pelo partido de massas na democracia partidária e, por fim, pelo catch-all na democracia de audiência.

Mas, se aceita a tese de que os partidos políticos estão em crise, Manin rejeita a avaliação de que essa crise se estende também à democracia representativa. A crise, diz Manin, não é do sistema representativo, mas sim dos partidos. E Manin vai além. Não considera que a debilidade dos partidos coloque em risco o sistema representativo. "Representative government remains what it has been since its foundation, namely a governance of elites distinguished from the bulk of citizens by social standing, way of life and 
education. What we are witnessing today is nothing more than the rise of a new elite and the decline of another" (grifo do autor), diz Manin (1997: 232). ${ }^{12}$

No aspecto da representação, como se verá mais adiante, Katz e Mair (2002) concordam com Manin, mas não compartilham a tese de que a crise dos partidos seja generalizada. Para tanto, resgatam os conceitos cunhados por Mair (1994) para analisar a organização dos partidos.

Para Mair, o erro fundamental da literatura que advoga a tese da crise generalizada dos partidos políticos é assumir que os partidos de massa são o modelo ideal de partido (Mair 1994: 2). A decadência desse tipo de partido é então, erroneamente, confundida com o enfraquecimento geral de todos os partidos. Mair, contudo, não vai ao outro extremo de avaliar que não há nada de errado com os partidos contemporâneos. Como veremos mais à frente, para ele, os partidos atuais não estão conseguindo dar conta da função representacional, um dos papéis clássicos que deveriam desempenhar. Nesse aspecto, segundo Mair, faz todo sentido falar em crise dos partidos. Mas em outras dimensões da vida partidária isso não é verdade.

Segundo Mair, a discussão a respeito da crise dos partidos ganha mais consistência quando diferentes aspectos da organização partidária são tomados separadamente. Mair propõe que as organizações partidárias sejam avaliadas segundo três facetas. Uma ligada às suas bases (party on the ground); outra a suas instâncias de comando interno (party in the central office); e, por fim, quando ocupa cargos públicos (party in the public office).

O primeiro deles, party on the ground, corresponde à organização partidária em suas bases, na relação com seus filiados, simpatizantes e eleitores. O party in the central office corresponde à direção do partido, às suas instâncias decisórias e o party in the public office é o partido em postos públicos eletivos ou não, no Executivo ou no Legislativo. É apenas na primeira destas dimensões, na relação com sua base de afiliados e eleitores, que os partidos enfrentam dificuldades. Como diz Mair, "the most powerful evidence which can be marshalled against the party decline thesis comes when we move away form the party on the ground, and begin to look at the resources available to the party central offices and to the parties in public office". (Mair 1994: 6)

O party on the ground era justamente a dimensão mais importante durante o período de predomínio dos partidos de massa. Nos partidos de massa, a base era responsável por determinar as diretrizes do partido. Tanto os dirigentes do partido, quanto os seus

\footnotetext{
${ }^{12}$ Ankersmit (2002) e Urbinatti (2006), autores também preocupados com a questão da representação política, rejeitam a visão de Manin de que o sistema representativo prescindiria dos partidos. Para eles, a crise dos partidos é também da própria democracia representativa.
} 
representantes eleitos ou os que ocupavam cargos públicos em nome do partido eram delegados da base. Cabia a estes obedecer aos comandos e diretrizes fixados pela base. Já no catch-all party, a relação da burocracia partidária e de seus dirigentes e políticos com a base tornou-se bem mais débil, até porque a própria base passou a ser fluida e menos identificável. A quantidade de filiados e simpatizantes deixou de ser a principal medida de força dos partidos. Assim, ao mesmo tempo em que o party on the ground perdeu importância, as outras duas dimensões da organização partidária se autonomizaram em relação às bases. A direção do partido passou a ser ocupada por profissionais ou por representantes dos políticos com cargos no governo e no parlamento, quando não por eles mesmos.

Tomando como base dados referentes a 12 países europeus e mais os Estados Unidos, Mair (1994) cita dois fatos como evidências da maior importância assumida pela direção partidária vis-à-vis a base do partido. O primeiro deles é o aumento expressivo do número de pessoas empregadas no staff dos partidos. Em 20 anos, do final da década de 60 até o final da década de 80 , o staff dos partidos nesses países cresceu entre $17 \%$ na Holanda a $330 \%$ na Irlanda. O segundo é a ampliação dos recursos financeiros dos partidos no mesmo período. Esses recursos não são os relativos a financiamento de campanha, mas os destinados à manutenção das atividades partidárias ordinárias. Dos 13 países avaliados, em apenas dois houve queda de receita: Suécia $(-4 \%)$ e Itália (-25\%). Nos demais, a receita cresceu, de $14 \%$ (Noruega) a 350\% (Alemanha). (Mair 1994: 7)

Mair conclui que "there is little to suggest any sense of decline of the party in public office, and hence there is also little to suggest any sense of party decline tout court. What we see instead are changing parties, in which the balance between the different faces is shifting, and in which, perhaps, they are also becoming more autonomous from one another". (Mair 1994: 12, grifo do autor).

Além de não separar as três dimensões da organização partidária, outro equívoco dos que advogam a tese do declínio dos partidos, conforme Katz e Mair, é ignorar a ligação entre os partidos e o Estado. Tradicionalmente, os partidos são avaliados segundo a conexão com a sociedade civil. Todos os modelos de partidos expostos até aqui - partido de quadros, de massas e catch-all - foram construídos e analisados segundo essa perspectiva. De acordo com Katz e Mair,

“(...) party continued to be evaluated primarily in terms of the linkage between party and civil society, and is precisely this linkage which was being undermined; hence, the voluminous literature on the 'decline of party'; and hence also the variety of different efforts to explain why parties might be able to survive such a change. If, instead, attention is paid to the linkages between party and the state, then both the survival and the evolution of party organization become more readily understandable" (Katz e Mair 1997: 96) 
Segundo Katz e Mair, a evolução dos modelos dos partidos apresentada acima, pode ser abordada de um ponto de vista dinâmico como sendo ilustrativa de um contínuo processo de afastamento dos partidos em relação à sociedade civil e, em contrapartida, de aproximação com o Estado. No período de predomínio dos partidos de quadros, Katz e Mair avaliam que havia uma interconexão entre o Estado e a sociedade civil, ou melhor, a elite composta pelos poucos abastados que, à época, formavam a comunidade política. Nesse período, os partidos eram pouco organizados e constituíam apenas agrupamentos de membros da elite pouco diferenciados entre si (Ibidem: 98). Com o avanço da industrialização e a ampliação da franquia eleitoral, sociedade civil e Estado se apartam mais nitidamente e os partidos, nessa conjuntura, se transformam em organizações da sociedade civil que fazem a conexão entre esta e o Estado. É o período dos partidos de massa (Ibidem: 100). Depois, no período catchall, os partidos perdem as claras conexões com a sociedade civil, pois não estão assentados em uma base determinada. Passam a servir, segundo a definição dos autores, como brokers entre a sociedade civil e o Estado. Essa relação é assim descrita por eles: "on one hand, parties aggregate and present demands from civil society to the state bureaucracy, while on the other they are agents of that bureaucracy in defending policies to the public". (Ibidem: 103)

Contudo, de acordo com esses autores, a aproximação entre os partidos políticos e o Estado avançou ainda mais nos últimos 20 ou 30 anos. Segundo Katz e Mair, a queda generalizada do envolvimento dos cidadãos nas atividades partidárias (Dalton e Wattenberg 2000), substituído pela militância em organizações mais abertas à participação efetiva do individuo e que normalmente priorizam questões unifacetadas - ecologia, por exemplo - ou locais, e, concomitantemente, a elevação dos custos de manutenção das atividades partidárias levaram os partidos a buscar a proteção financeira do Estado. Houve aumento das subvenções estatais aos partidos. Ao mesmo tempo, a extrema importância que assumiram os meios de comunicação de massa (rádio e tv) para a divulgação das mensagens dos partidos dentro e fora das campanhas eleitorais os posicionou em um ambiente naturalmente propício à regulamentação e ao controle estatal. Em conjunto, esses processos fizeram com que

\footnotetext{
"the state $(\ldots)$ becomes an institutionalized structure of support, sustaining insiders while excluding outsiders. No longer simple brokers between civil society and the state, the parties now become absorbed by the state. From having first assumed the role of trustees [partido de quadros], and then later of delegates [partido de massa], and then later again, in the heyday of the catchall party, of entrepreneurs, parties have now become semi-state agencies" (I bidem: 106).
}

Esse tipo de partido, qualificado por Katz e Mair como uma "agência semi estatal", é o que eles chamam de partido cartel. O termo cartel vem da economia e das relações comerciais 
e negociais entre empresas. Representa a ideia de conluio entre empresas ou organizações a princípio concorrentes, mas que se unem e acordam estratégias e ações que visam a favorecêlas conjuntamente. O cartel representa também um arranjo defensivo contra a entrada de novos concorrentes no mercado econômico ou, no caso dos partidos, no mercado político. É exatamente o que fazem os partidos cartel. Com a agravante de que, em relação aos partidos, são eles mesmos os autores das regras e da legislação que favorecem as organizações partidárias já instituídas e criam barreiras à entrada de novatos ou ao fortalecimento de legendas já existentes mas que não fazem parte do grupo de partidos ganhadores, digamos assim, isto é, daqueles que participam ou já participaram de governos, como protagonistas ou como aliados. ${ }^{13} \mathrm{~A}$ passagem pelo governo aliás é outra característica dos partidos cartel destacada por Katz e Mair. Segundo eles, a maioria dos partidos relevantes europeus já passou pela experiência de fazer parte de governos nacionais ou regionais. É mais um elemento que reforça a tese dos dois autores de que os partidos passaram a fazer parte de um arranjo especialmente poderoso visto que seus próprios membros são, em última instância, os responsáveis pelo ordenamento legal que sustenta o cartel.

Visto dessa forma, parece um sistema inexpugnável que tende a se auto fortalecer. Afinal seus beneficiários são, ao mesmo tempo, os responsáveis pelo regramento que o sustenta. Não é bem assim, afirmam Katz e Mair. Há dois fatores externos que limitam o cartel.

O primeiro são as normas constitucionais e o poder judiciário. Eles citam decisões das cortes supremas da Alemanha e do Canadá favoráveis a pequenos partidos que, sem a intervenção da justiça, corriam o risco de não receber subsídios estatais concedidos aos grandes partidos. ${ }^{14}$

O segundo é a exacerbação do sentimento anti partidário que parece predominar nas atuais democracias representativas. Tal sentimento, conforme os autores, propiciou o fortalecimento de partidos populistas portadores de discurso crítico ao sistema partidário. Na Europa, foco principal da atenção deles, a disputa contra o mainstream partidário é empreendida essencialmente por partidos de extrema direita. "Cartelization has clearly contributed to the rise of populist anti-party system parties that appeal directly to public

\footnotetext{
${ }^{13}$ Bom exemplo brasileiro do comportamento de cartel assumido pelos partidos políticos foi a aprovação no final de 2010 de uma emenda ao Orçamento Geral da União a qual aumentou em R\$ 100 milhões a verba destinada ao Fundo Partidário para 2011. A emenda foi apoiada por praticamente todos os partidos com representação no Congresso. A maioria deles estava endividada por causa das despesas com a campanha eleitoral de 2010 .

${ }^{14}$ No Brasil, decisão semelhante foi tomada pelo Supremo Tribunal Federal (STF) em dezembro de 2006. O STF declarou inconstitucional artigo da Lei 9.096/1995 que criou a cláusula de desempenho segundo a qual os partidos que não ultrapassassem a marca de 5\% dos votos para a Câmara dos Deputados perderiam acesso ao Fundo Partidário, à propaganda partidária gratuita no rádio e na televisão e a algumas prerrogativas parlamentares no Congresso Nacional.
} 
perceptions that the mainstream parties are indifferent to the desires of ordinary citizens". (Katz e Mair 2009: 759)

O afastamento do partidos em relação à sociedade civil e a concomitante aproximação do Estado, processo que propiciou o surgimento dos partidos cartel, estão na raiz da aversão aos partidos, argumentam Katz e Mair. Assim, se a cartelização fortaleceu a face party in the public office, exacerbou, em contrapartida, um problema crucial para os partidos e para a democracia contemporâneos: a representação política. Os autores avaliam que os partidos, na medida em que privilegiaram seu papel governativo, deixaram de cumprir a sua função representativa, isto é, não são mais capazes de preencher adequadamente o gap representativo entre a sociedade e o Estado. Segundo eles, "the current situation is characterized by an enhancement of the partyness of government - as reflected in enhanced levels of recruitment, nominations and office-holding - but a dissolution of the partyness of society" (Ibidem: 760). E isso traz um risco para os partidos: a da perda de legitimidade como organização política. "Unless parties can represent as well as govern, it may turn out to be more and more difficult for them to legitimize their command of governmental institution and appropriation of public resources" (I dem). Ou seja, no limite, a desconexão com a sociedade e a consequente perda de legitimidade, poderá também prejudicar a função governativa exercida pelos partidos. Nos termos propostos pelos autores, o enfraquecimento do party on the ground poderá afetar também o party in the public office.

Ademais, a perda de legitimidade dos partidos debilitaria o argumento utilizado pelas lideranças partidárias para justificar a aprovação de medidas - a apropriação de recursos do Estado, por exemplo - que Ihe são favoráveis. Tais medidas são comumente apresentadas pelas cúpulas partidárias como necessárias para o fortalecimento da própria democracia. Aproveitam-se da ideia de que, para citar a famosa frase de E. E. Schattschneider (1942), "modern democracy is unthinkable save in terms of the parties". Porém, essas medidas são crescentemente percebidas pela maior parte do eleitorado como sendo favoráveis apenas à elite partidária e ao cartel formado pelos partidos integrados ao núcleo do sistema partidário. Nesse sentido, o enfraquecimento da função representativa dos partidos põe em cheque a ideia de que os partidos são uma instituição fundamental para a democracia moderna. O problema é que, como disse Schattschneider, a democracia moderna de fato é ainda impensável sem os partidos.

Retornar ao modelo partido de massa, no qual a função representativa era central, não é uma alternativa dizem Katz e Mair. Não é mais um modelo adequado às condições sociais e econômicas predominantes no mundo moderno. Restam então questões que parecem irrespondíveis no momento. Será possível reverter o processo de burocratização dos partidos e seu contínuo alheamento da sociedade? As mudanças estruturais ocorridas na sociedade nos 
últimos 30 ou 40 anos - emergência de novas divisões do trabalho, o rebaixamento e o embaralhamento das ideologias por conta do fracasso da via socialista, a ampliação do alcance da mídia, a crescente personalização da política, entre outros - não tornaram irremediavelmente obsoleto e anacrônico o sistema partidário?

Contudo, a despeito de enfraquecidos, os partidos continuam existindo e têm ainda um papel importante no processo eleitoral e, como vimos, também no exercício do governo, seja no âmbito do Parlamento ou do poder Executivo. Há poucos países que permitem candidaturas avulsas, desatadas do vínculo partidário. Como as eleições ainda são o meio mais importante de acesso ao poder nos regimes democráticos, os partidos, mesmo enfraquecidos, continuam no centro do poder político. Ao mesmo tempo, passados já 30 ou 40 anos da propalada crise de representação centrada nos partidos políticos, não parece existir nenhum movimento realmente inovador no sentido de reformar os partidos e de tonificar-lhes a função representativa. Assim, um risco evidente é que os partidos permaneçam ainda durante muito tempo como uma espécie de cadáver insepulto da democracia representativa. Insepulto, mas poderoso.

Para finalizar esta discussão, vale a pena citar um longo trecho de um paper de Mair no qual ele discute as dificuldades para se conciliar os atributos da representação e da governabilidade na democracia contemporânea. Serve como síntese das discussões apresentadas acima.

"The unique contribution parties offered to the development of modern
democracy and the process of legitimizing democracy was that they combined
these crucial two roles [representation and govern]. That is, the key
representative and governing functions of the polity were developed within an
organization - the party. The same organization that governed the citizenry also
gave that citizenry voice, and the same organization that channeled
representation also managed institutions of the polity. This was the key to the
legitimation of representative government in democratic political systems. (...)

In contemporary democracy, the two functions that were once combined by party have begun to grow apart, with many of today's parties downplaying, or being forced to downplay, their representative role, and enhancing, or being forced to enhance, their governing role. In other words, as part of the process by which parties moved their center of gravity from civil society to the state, they have also begun to shift from combining representative and governmental (procedural or institutional) roles of strengthening their governmental role alone.

Another way of looking at this suggest that parties have moved from representing interests of the citizens to the state to representing interests of the 
state to the citizens. Meanwhile, the representation of the citizens, to the extent that it still occurs at all, is given over to other, nongoverning organizations and practices - to interest groups, social movements, advocacy coalitions, lobbies, the media, self-representation, etc. - that are disconnected from the party system. In this way, representation becomes less and less a function of the activities of partisan political organizations and more and more something that is realized through a contemporary and often depoliticized version of pluralism. (Mair 2009: 5-6).

Isso provoca um fenômeno que Mair denomina de bifurcação: "There is a growing bifurcation in European party systems between parties which claim to represent but don't govern and those which govern but no longer represent". (Ibidem: 17)

Um esquema alternativo ao de Katz e Mair é o apresentado por Wolinetz (2002). Wolinetz tem uma visão crítica a respeito da teoria do partido cartel defendida por Katz e Mair. ${ }^{15}$ Ele considera que a tese dos dois autores é interessante, mas problemática. Segundo ele, "other than noting that almost all parties have at one time or another governed or joined coalitions, they give very little evidence of ways in which parties' behavior may have changed because of increased state support" (Wolinetz 2002: 2202-2203). Wolinetz também critica a hipótese, presente nos argumentos de Katz e Mair, de que haveria uma tendência generalizada a que os partidos, ou pelo menos os mais relevantes, convirjam para o modelo partido cartel. Nesse aspecto, a crítica de Wolinetz, não se restringe apenas a Katz e Mair. Estende-se a todos os modelos que supõem haver convergência entre as formas de organização e atuação de diferentes partidos. Essa ideia, de acordo com Wolinetz, é uma simplificação grosseira da realidade. Enquadrar partidos em determinados moldes é um exercício estéril, dada a heterogeneidade das organizações partidárias.

Em substituição aos modelos pós catch-all, nos quais ele inclui o partido cartel, Wolinetz defende que a análise dos partidos seja feita com base em três tendências ou orientações a partir das quais seria possível caracterizar os partidos mais adequadamente tanto do ponto de vista de sua organização quanto de sua atuação política. Os partidos podem ter três orientações fundamentais. Podem ser vote-seeking, policy-seeking ou office-seeking. Essa classificação, informa Wolinetz, foi formulada originalmente por Strom (1990), para analisar a formação de coalizões partidárias.

Um partido vote-seeking é aquele que adota como principal objetivo conquistar o maior número possível de votos e ganhar eleições. Fazendo um paralelo com os modelos expostos no

\footnotetext{
${ }^{15}$ Koole (1996 ) é outro autor que critica o partido cartel.
} 
começo deste capítulo, são partidos essencialmente de tipo catch-all. ${ }^{16} \mathrm{Na}$ vertente policyseeking, o objetivo principal é defender uma política (ou políticas) pública(s). São mais próximos aos partidos de massa, considerando-se que estes, em seu formato original, estavam voltados à defesa de políticas direcionadas à sua base social e ideológica. Já o partido officeseeking busca essencialmente conquistar acesso a cargos no governo mesmo que, para isso, seja obrigado a adotar estratégias não maximizadoras de voto, como por exemplo, abrir mão de candidaturas para compor coligações. Estes, obviamente, são próximos ao modelo partido cartel de Katz e Mair.

Assim como nenhum partido se enquadra plenamente nos modelos comumente utilizados (massa, catch-all e cartel), Wolinetz reconhece que nenhum partido adota exclusivamente uma dessas orientações e que estas tampouco são independentes. Normalmente, há uma combinação entre duas dessas orientações. Porém, segundo Wolinetz, é possível identificar ênfases diferenciadas a cada uma dessas orientações e, geralmente, pelo menos uma delas é colocada em segundo plano na estratégia dos partidos. Como argumentaremos mais adiante, o modelo defendido por Wolinetz é útil para analisar as mudanças que ocorreram no PFL após a sua passagem para a oposição.

\section{I.2 - O debate sobre partidos no Brasil}

O ponto mais discutido pela ciência política brasileira nos últimos anos em relação aos partidos tem sido o da institucionalização do nosso sistema partidário pós-redemocratização. Essa questão suscitou acirrado debate entre os pesquisadores que se dedicaram ao tema. A respeito desse tópico há duas correntes que, à falta de melhores nomes, chamaremos de "reformistas", de um lado, e de "empiristas-relativistas", de outro17. Tais denominações, é preciso reconhecer, são bastante reducionistas das posições e características dos autores de cada uma dessas correntes. Provavelmente nenhum desses autores se sentiria confortável com essa classificação, visto que, entre os reformistas, há quem utilize amplamente a pesquisa empírica e mesmo os que não o fazem certamente acreditam que suas análises estão ancoradas na realidade perceptível da política brasileira. Além disso, tampouco concordariam com a idéia de que analisam o caso brasileiro de olhos vendados para o que ocorre nas democracias de outros países. Entre os empiristas/relativistas, por sua vez, muitos também

\footnotetext{
${ }^{16}$ Wolinetz também considera que o vote seeking party é um partido de tipo downsiano, isto é, que se orienta exclusivamente à disputa eleitoral e ajusta a sua posição a respeito de políticas com o único objetivo de conquistar o maior número de votos possível.

${ }^{17}$ Peres (2004: 88) usa os termos “comparativos” e "revisionistas” para os dois grupos. Os comparativos equivalem, na nossa denominação, aos reformistas; e os revisionistas aos empiristas/relativistas. Comparativos, porque, segundo Peres, estes são "analistas de política comparada [que] têm mirado seu foco de investigação apenas nas regras eleitorais e na forma de governo" ao passo que "os analistas ‘revisionistas’ têm procurado mostrar que variáveis internas ao processo legislativo, variáveis relativas aos poderes legislativos do presidente, variáveis inerentes à competição eleitoral, etc, podem levar a uma outra concepção acerca do funcionamento da democracia brasileira”.
} 
defendem a necessidade de o sistema político partidário brasileiro passar por reformas, embora não tão abrangentes quando às defendidas pelo primeiro grupo. Contudo, ao nomeálos dessa maneira, pretendemos salientar pontos importantes que os diferenciam. $O$ enfoque reformista é mais central para o primeiro grupo, assim como o trabalho empírico e a abordagem relativista - isto é, o cuidado de cotejar os problemas da democracia brasileira com os vivenciados por outros países democráticos - o são para o segundo grupo.

É preciso reconhecer ainda que esses não são grupos homogêneos. Ou seja, há diferenças entre autores alocados em cada um deles. Mas o que os aproxima internamente e o que os afasta do grupo oposto é a avaliação sobre a qualidade da democracia brasileira e particularmente do sistema partidário brasileiro.

\section{REFORMISTAS}

Para os reformistas, uma das características mais importantes do sistema político brasileiro construído após o fim do regime militar de 1964 é a fragilidade do sistema partidário. A frase que abre o livro Partidos Políticos e Consolidação Democrática: o Caso Brasileiro, de Lamounier e Meneguelo (1986), é emblemática dessa corrente: "em perspectiva comparada, o Brasil é um caso notório de subdesenvolvimento partidário"18. Esta não seria uma peculiaridade do período pós redemocratização. Ao contrário, a fragilidade dos partidos políticos brasileiros seria recorrente na história do país. A própria frase destacada acima está inserida em um contexto histórico mais amplo. Refere-se à situação dos partidos ao longo da história brasileira desde o Império. Contextualizada historicamente, a afirmação perde um pouco de seu conteúdo polêmico. Mesmo assim, é simbólica da avaliação negativa a respeito do sistema partidário brasileiro.

Nessa perspectiva, os partidos seriam incapazes de gerar afinidades e identidades razoavelmente estáveis e significativamente amplas com eleitores e com segmentos sociais relevantes (Kinzo 2004 e 2005). Além de instável e restrita a uma parcela diminuta da população, a identificação dos eleitores com os partidos teria bases precárias desprovidas de conteúdo mais sólido e significativo. Estaria baseada em “imagens de pouca sofisticação cognitiva e ideológica" (Reis, 2000: 324), de modo que "nos amplos setores pobremente informados e precariamente envolvidos no processo político, o que parece estar em jogo são antes identificações difusas e 'projetivas' estabelecidas em torno de imagens bastante simples da estrutura social e das clivagens que a definem". (Ibidem: 320)

\footnotetext{
${ }^{18}$ A posição de Meneguelo mudou significativamente em obras posteriores (ver Meneguelo 1998). Não é o caso de Lamounier, que continua a sustentar avaliação bastante crítica a respeito do sistema partidário brasileiro, como ilustra essa afirmação: “As deficiências da organização partidária brasileira vêm de longe e parecem estar se agravando” (Lamounier 2005: 254).
} 
Ao mesmo tempo, como outra face do problema da falta de identidade partidária, os partidos brasileiros, em geral, seriam carentes de feições programáticas e ideológicas próprias, tornando-se pouco distintos entre si. Outra característica dos partidos brasileiros seria a baixa fidelidade dos políticos a eles filiados, que se manifestaria mais enfaticamente por meio da elevada taxa de migração partidária (Melo 2004).

Para os reformistas, a excessiva fragmentação partidária existente no país também é um elemento disfuncional para o nosso sistema político. No plano congressual, a fragmentação representaria um problema para a governabilidade na medida em que imporia dificuldades à sustentação política dos presidentes e à aprovação de reformas consideradas necessárias à estabilidade e ao desenvolvimento econômico (Lamounier 1992 e 1994).

Por conta da fragmentação partidária, nenhuma legenda, desde 1990, tem conseguido formar bancadas fortemente majoritárias. As mais fortes alcançam no máximo algo próximo a 20\% dos assentos na Câmara dos Deputados e no Senado. Consequentemente, para garantir maioria no Congresso, os presidentes ficam obrigados a compor alianças muito amplas e heterogêneas, e, por conseguinte, frágeis, pouco coesas e leais. A heterogeneidade da base de sustentação no Congresso se refletiria na composição do ministério, fatiado entre as (muitas) forças políticas que apóiam o governo. Nesse presidencialismo de coalizão (Abranches 1988), a montagem dos governos fica condicionada não apenas à força dos vários partidos da base governista no Congresso, mas também ao poder político dos governadores, cujo poderio se rivaliza com o dos presidentes (Abrúcio 1998) entre outras razões porque exercem forte influência na eleição dos deputados federais (Samuels 1998), o que thes garante ascendência sobre parcelas importantes do Congresso. A ação dessas múltiplas forças políticas resultaria na formação de ministérios fracionados que dificultariam a elaboração e aplicação de políticas públicas harmônicas.

Ao mesmo tempo, a necessidade de manter maiorias na Câmara e no Senado - às vezes qualificadas ( $3 / 5$ dos votos), no caso da aprovação de emendas constitucionais -, nesse ambiente conformado pela fragmentação e pela infidelidade partidária, acarretaria distorções ao sistema político brasileiro. Privilegiaria a troca de favores entre o Executivo e parlamentares ou grupo de parlamentares, não necessariamente pertencentes a um mesmo partido bancada dos ruralistas, por exemplo. E esta seria uma situação propícia à corrupção política, ou, no mínimo, à existência de relações pouco institucionalizadas e pouco transparentes entre o Executivo e o Congresso (Mainwaring 1999: 223-270).

Esse conjunto de fatores produz avaliações bastante críticas ao sistema partidário brasileiro, que é considerado pouco institucionalizado, confuso do ponto de vista ideológico e programático, incapaz de gerar fidelidades com o eleitor e de manter, dentro de cada legenda, um conjunto coeso de políticos. Em suma, é um sistema falho que não consegue cumprir a 
contento os tradicionais papeis reservados aos partidos políticos em uma democracia representativa. Não é capaz nem de representar a sociedade nem de garantir a governabilidade do país. Não serve de instrumento para aumentar a inteligibilidade do sistema político para o cidadão. Tampouco favorece a accountability do governo, dos partidos e dos políticos eleitos para o Congresso.

Como diz Mainwaring:

\begin{abstract}
“No período pós-1985, o sistema partidário brasileiro tem se mostrado pouco institucionalizado. A alta volatilidade eleitoral é um indicador da limitada estabilidade dos padrões de competição interpartidária. A reduzida penetração dos partidos na sociedade se manifesta nos baixos níveis de identificação com os partidos, na ausência do voto partidário, nas profundas descontinuidades dos padrões de apoio aos partidos e na opinião dos eleitores de que o partido não determina seu voto" (Mainwaring 1999: 178).
\end{abstract}

Ou Ames

"Even by Latin American Standards, Brazil's party system is weak. Few parties have genuine roots in society. Party votes are volatile over time and between presidential and legislative elections. In the Congress, party leaders exert little control over their delegation. Many if not most deputies spend the bulk of their time arranging jobs and pork-barrel projects for their benefactors and constituents. Though electorally successful parties span a wide ideological range, some of the largest 'center' parties are really just shells for deputies with no policy interests at all. Few parties organize around national-level questions; the Congress, as a result, seldom grapples with serious social and economic issues. Brazil's presidents benefit little from the weakness of the Congress. With only minimal chances to obtain stable legislative support, executives face independent governors, an electoral calendar imposing elections in three of every five years, municipalities depending for their very survival on federal largesse, and a substantial core of deputies who value their own income first, reelection second, and public a distant third. Presidents govern by forming coalitions based upon cabinet appointments. Because these appointments must satisfy both party and regional demands, cabinets tend to be very inclusive (Abranches 1988). The pork-barrel programs required to maintain them are costly, and policy innovation is extremely difficult" (Ames: 1995: . 407).

Além de fatores históricos - a extinção forçada dos partidos políticos brasileiros provocada pela Revolução de 30 e, posteriormente, pelo Golpe de 64 -, razões de ordem institucional são apontadas como responsáveis pela fragilidade do sistema partidário brasileiro. O desenho institucional vigente desde a redemocratização é considerado impróprio à consolidação do sistema partidário. A combinação entre presidencialismo plebiscitário e o federalismo, arranjo considerado problemático para a sustentação de regimes democráticos, é 
agravada pela convivência com um sistema eleitoral que seria sui generis, utilizado por poucos países no mundo - Finlândia e Chile são os mais citados -, no qual os deputados federais e estaduais e os vereadores são eleitos por meio de lista aberta e voto uninominal. O sistema eleitoral de lista aberta é considerado por muitos como a causa principal para a inexistência de vínculos mais sólidos entre os eleitores e os partidos, visto que reduziria a importância das legendas para a obtenção do mandato parlamentar. Como diz Ames (1995: 407), "at the core of Brazil's crisis lies the electoral system". Para este:

\begin{abstract}
"Faced with an electoral system whose chief attributes include open-list proportional representation, large multimember districts, candidates selection at the level of politically active subnational units, and the possibility of immediate reelection, most deputies pay little attention to ideological appeals. (...) Brazil's electoral system hinders voter control. It forces candidates to seek single-issue niches, to spend lavishly, and to make deals with candidates for other offices, candidates with whom they have nothing in common. (...) In the legislative process, Brazil's system produces parties without programs, parties sheltering an enormous range of interests and preferences. Open-list proportional representation is not a sufficient condition for weak parties; pre-1973 Chile combined open-list PR with fiercely ideological parties. But open list PR in Brazil works differently, because state interests control nominations, because parties cannot control the behavior of their deputies, and because high district magnitudes increase both inter- and intra- fragmentation" (Ames 1995: 430431).
\end{abstract}

Na avaliação de Mainwaring (1999: 302), "as regras eleitorais brasileiras estimulam os políticos a cultivarem o voto pessoal e a evitarem uma dependência muito grande do partido. O sistema eleitoral ajuda a explicar o comportamento individualista dos políticos e contribui para a baixa institucionalização do sistema partidário. O baixo grau de lealdade nos partidos catch-all é incentivado pelo próprio sistema eleitoral".

Inevitavelmente, a partir desse retrato sombrio do sistema político partidário brasileiro chega-se a conclusões pessimistas quanto ao futuro da democracia no Brasil. Nos primórdios da redemocratização, temia-se que a confusão institucional, poderia gerar tensões capazes de redundar em nova quebra do regime democrático. A citação abaixo de Mainwaring sintetiza bem os efeitos deletérios da fragilidade do sistema partidário sobre o sistema político brasileiro:

\footnotetext{
“Em situações de competição interpartidária instável, o mercado eleitoral se torna mais aberto e os resultados menos previsíveis. Outros fatores mantidos constantes, é provável que essa situação aumente a incerteza dos atores sobre a desejabilidade da democracia, torne mais difícil a avaliação dos partidos pelos eleitores, aumente a probabilidade de mudanças significativas nas políticas públicas e intensifique o rodízio dos membros do Legislativo. Nas situações em
} 
que os partidos são pouco enraizados na sociedade, é provável que as campanhas e os resultados eleitorais sejam dominados pelo personalismo e isso pode prejudicar a accountability do sistema. A baixa legitimação dos partidos facilita a eleição de políticos de orientação antipartidária. Finalmente, quando as organizações partidárias são frágeis, é provável que os líderes sejam mais importantes como indivíduos e que práticas ad hoc sejam mais difundidas" (Mainwaring 1999: 379).

A solução para corrigir tais distorções seria a reforma política - daí a alcunha de reformistas que utilizamos para nomear essa corrente -, especialmente do sistema eleitoral. A lista aberta deveria ser substituída pela lista fechada, ou pelo voto distrital, ou por uma combinação entre esses dois sistemas. Cláusulas de desempenho para a existência ou para a capacidade de os partidos elegerem representantes no Congresso também fazem parte, de maneira recorrente, da lista de medidas recomendas para a reforma política. Na agenda da reforma política, constou também durante vários anos a adoção do parlamentarismo. A derrota da opção parlamentarista na Constituinte de 1988 e, de forma bastante categórica, no Plebiscito de 1992, retirou na pratica esse tema do conjunto de iniciativas propostas pelos defensores da reforma política.

\section{EMPI RI STAS - RELATI VISTAS}

É bastante distinta a avaliação que os empiristas-relativistas fazem do sistema político partidário brasileiro. Ao contrário dos reformistas, estes sustentam que não há nada de muito errado nem no sistema político, nem no sistema partidário brasileiro. Os males do sistema político costumeiramente apontados ou não seriam de fato problemas ou perderiam relevância caso analisados em perspectiva mais ampla, ou seja, à luz do que ocorre em outras democracias do mundo ${ }^{19}$. Assim, o sistema político brasileiro nem seria tão disfuncional nem tão singular como os autores reformistas argumentam.

Para os empiristas-relativistas, o diagnóstico a respeito da precária institucionalização do nosso sistema político e partidário teria sido algo mais assumido do que claramente demonstrado. Os autores da corrente reformista teriam partido de pré-concepções a respeito do que caracterizaria um sistema político adequado ou funcional e as teriam aplicado ao Brasil sem o devido cuidado empírico de analisar como funciona de fato o sistema político brasileiro. Paradigmático da corrente empirista-relativista é o trabalho de Figueiredo e Limongi (1995), no qual eles mostram que, ao contrário do que se afirmava correntemente, é elevada a

\footnotetext{
${ }^{19}$ Quanto à falta de uma perspectiva comparada no estudo da democracia brasileira, diz Limongi: “Avaliações sobre a política brasileira tendem a ser concluídas com a expressão: ‘só mesmo no Brasil para algo assim ocorrer’. Em realidade, no mais das vezes, afirmações deste tipo evidenciam que sabemos muito pouco sobre como funcionam as democracias modernas. A democracia é uma forma de governo assaz imperfeita e muito do que acreditamos ser característico de nosso subdesenvolvimento são características gerais das democracias” (Limongi 2001: 2-3).
} 
disciplina partidária na votação de projetos no Congresso. Dessa forma, assim como esses dois autores fizeram a respeito das votações no Congresso, antes de condenar o sistema político brasileiro, haveria necessidade de desenvolver trabalhos empíricos mais focados, voltados a discutir, por exemplo, a relação entre o Executivo e o Congresso, a migração partidária, a competição entre os partidos na arena eleitoral, a volatilidade eleitoral, o recrutamento de quadros partidários, entre outros temas. Somente após essa agenda de pesquisa ter sido desenvolvida seria legitimo falar em reforma política.

Um dos principais autores dessa corrente é Fernando Limongi que, desde meados dos anos 90, vem empreendendo e estimulando uma agenda de pesquisa de marcante caráter empírico voltada à análise do sistema político brasileiro.

São diversas as críticas lançadas por Limongi contra os reformistas. Em primeiro lugar, ele considera problemática a base teórica que, na sua avaliação, sustenta as análises de alguns autores pertencentes ao grupo que chamamos de reformistas. Na visão de Limongi (1999 e 2002), Huntington e Sartori seriam os autores fonte para os reformistas, em especial para Lamounier e Reis, dois de seus contendores mais frequentes. O que Limongi contesta com mais vigor na matriz institucionalista huntington-sartoriana é a ideia de que as condições econômicas, sociais e culturais - de cultura política, bem entendido - prevalecentes em países subdesenvolvidos constituiriam obstáculos importantes à consolidação da democracia nessas sociedades. Segundo tal matriz, o descongelamento das pressões por melhorias sociais e pela melhor distribuição de renda que acompanharia o restabelecimento das instituições democráticas representaria um risco para as democracias recentes. A impossibilidade de atender tais demandas no curto prazo colocaria em xeque as nascentes democracias, tornando-as alvos fáceis do populismo. No caso brasileiro, tal risco estaria maximizado por conta das deficiências institucionais de nosso arranjo político que levaria, como vimos, à paralisia decisória e ao alheamento entre o sistema político e a sociedade.

Desse modo, na interpretação de Limongi, a defesa da reforma política, da substituição do sistema proporcional pelo majoritário, por exemplo, ou da limitação ao número de partidos, teria como objetivo precípuo conter o ímpeto das massas desordenadas. O principal problema do sistema político brasileiro seria sua incapacidade de moderar as demandas populares.

\footnotetext{
“No Brasil, deu-se por assentado que a adoção das instituições pede referência ao suposto estágio de desenvolvimento político em que o país se encontra. 0 Brasil seria um país pretoriano e enquanto tal deveria adotar as instituições adequadas aos países pretorianos. Entre elas estão as que fortalecem os partidos, isto é, as que restringem as opções dos eleitores. Esta seria a única forma de evitar a radicalização política. (...) As massas, seus valores e
} 
interesses são tomados como a principal ameaça à ordem democrática" (Limongi 2002: 71)..$^{20}$

A partir dessa matriz huntington-sartoriana, os reformistas teriam assumido como evidentes as deficiências da democracia brasileira e não teriam se preocupado em estudá-las de fato.

\begin{abstract}
“A certeza de que a democracia brasileira não funcionaria adequadamente levou à atrofia dos estudos empíricos sobre essa mesma democracia. Juízos realistas tomaram o lugar dos juízos empiricamente fundamentados. Se a democracia brasileira é ou não baixamente institucionalizada e inerentemente instável; se as pressões populares por redistribuição levam ou não à explosão das demandas; se o eleitor brasileiro é ou não capaz de se orientar em um sistema político que Ihe oferece múltiplas opções; se a volatilidade eleitoral é baixa ou alta, e se as oposições sempre derrotam a situação são questões que pedem verificação empírica sistemática. A literatura sobre institucionalização política gerou uma significativa agenda de pesquisas que ainda aguarda tratamento e resposta adequados" (Limongi 1999: 143).
\end{abstract}

Em conjunto com Argelina Figueiredo, o próprio Limongi se dedicou a cobrir uma parte dessa agenda de pesquisa. Como já dissemos, Figueiredo e Limongi (1995), em trabalho que se tornou referência obrigatória na ciência política brasileira aplicada aos estudos sobre o Congresso, seus mecanismos de decisão e sua relação com o Executivo, confrontaram a tese geralmente aceita de que os partidos no Congresso seriam indisciplinadas, teriam comportamento errático e atuariam em bases não partidárias. Estudando as votações na Câmara dos Deputados entre 1989 e 1994, chegaram a resultados que contradisseram a visão predominante. Ao contrário do senso comum, encontraram um quadro de acentuada disciplina partidária. Na grande maioria das votações, as bancadas seguiram em peso a orientação do líder do partido ou da coalizão. Adicionalmente, concluíram que os projetos encaminhados pelo Executivo à Câmara têm grande chance de serem aprovados. Os autores atribuem tais fatos aos poderes de agenda atribuídos pela nova Constituição ao Presidente da República (prerrogativa do veto total ou parcial, ampla capacidade de iniciativa parlamentar, possibilidade de legislar por meio de medidas provisórias e condição de determinar a forma de tramitação dos projetos no Congresso por meio do pedido de urgência) e à organização interna dos trabalhos legislativos, a qual privilegia a atuação dos líderes partidários. Assim, pelo menos do ponto de vista da atuação parlamentar, a afirmação de que os partidos beiram a irrelevância tornou-se no mínimo controversa. ${ }^{21}$

\footnotetext{
${ }^{20}$ Por certo, nem Lamounier nem Reis concordam com essa interpretação a respeito de seus trabalhos. Nesse debate, coube a Reis formular uma resposta mais direta a Limongi (ver Reis 1999).

${ }^{21}$ Para uma crítica às conclusões de Figueiredo e Limongi (1995), ver Lamounier (2005: 242-246).
} 
Santos (1997) também chega a conclusões parecidas às de Figueiredo e Limongi quanto à capacidade do Executivo de conquistar apoio do Congresso à sua agenda parlamentar. Segundo ele, "a decisão de deputados de participar da base de apoio presidencial dependerá não somente do grau de concordância com o programa de governo, mas também do acesso dado por essa cooperação a cargos políticos". (Santos 1997: 472)

Se os resultados e as conclusões de Figueiredo e Limongi e de Santos estão corretos, reduz-se a solidez dos argumentos que relacionam a alegada debilidade dos partidos à inoperância do Executivo e aos riscos para a governabilidade. Não há porque se falar em ingovernabilidade, entendida como a dificuldade de o governo levar adiante suas propostas por falta de apoio parlamentar, se os dados indicam que é elevada a taxa de sucesso das iniciativas legislativas patrocinadas pelo Executivo.

Em trabalho que também teve como objeto a atuação legislativa do Congresso, Ricci (2003) contradiz outra visão comum a respeito do sistema político brasileiro. Segundo ele, ao contrário do ponto de vista predominante, "é enganoso pensar que a produção legislativa do Congresso esteja relacionada com tendências meramente paroquiais. Alias, pelos dados oferecidos, parece evidente que o Congresso age mais com o objetivo de produzir normas de impacto geral e seccional e, de forma menos expressiva, projetos distributivos de impacto amplo" (Ricci 2003: 723-724). Coloca-se em suspeição, portanto, a tese de que o sistema eleitoral brasileiro favoreceria o atendimento a demandas localistas.

Amorim Netto (1999), por sua vez, relaciona a conquista do apoio parlamentar majoritário à capacidade dos presidentes da República de formar gabinetes que reflitam a força dos partidos no Congresso. É uma análise que incorpora o conceito de presidencialismo de coalizão cunhado por Abranches, mas que Ihe dá uma interpretação mais positiva. Amorim Netto argumenta que, caso o presidente cumpra a regra de distribuir os postos ministeriais entre os partidos de maneira proporcional ao de suas bancadas no Congresso, o presidencialismo de coalizão brasileiro funcionaria bem e seria capaz de garantir boa operosidade ao Executivo. O primeiro mandato do presidente Fernando Henrique Cardoso é apresentado como o exemplo mais bem sucedido do presidencialismo de coalizão, ao passo que o governo Collor de Mello seria o exemplo negativo.

Já Nicolau (1996) questiona outro conceito bastante disseminado a respeito da relação entre o sistema eleitoral para a eleição de deputados (lista aberta) e a fragmentação partidária. Segundo ele:

\footnotetext{
"As conclusões a respeito do possível impacto do sistema eleitoral sobre o multipartidarismo vão de encontro às tradicionais interpretações sobre o tema: o sistema eleitoral brasileiro é composto por mecanismos que favorecem os
} 
maiores partidos, muito embora a alta magnitude de alguns distritos tenda a tornar mais fácil a representação dos menores partidos. (...) Podemos então concluir que o sistema eleitoral brasileiro não é a causa da fragmentação partidária. Para tal, seria necessário que ele favorecesse os menores partidos, o que não ocorre. Portanto, se o multipartidarismo extremado foi uma marca do sistema partidário brasileiro no período 1988-95, suas causas devem ser buscadas em outras esferas do sistema político". (Nicolau 1996: 62)

A concepção de que o arranjo partidário vigente no país desde o final dos anos 80 seria instável e tendente à desestruturação é também contestada. Peres (2004), por exemplo, com base no cálculo da volatilidade das eleições para a Câmara dos Deputados desde 1990 chega à conclusão de que a instabilidade da decisão do voto, uma das medidas normalmente usadas para testar a institucionalização de um sistema político partidário, não é muito pronunciada. Em comparação com a volatilidade existente em outras democracias, a instabilidade no Brasil poderia ser classificada como média. A conclusão é ainda mais forte quando se mede a volatilidade ideológica do voto. Agrupando os partidos no contínuo direita-esquerda, Peres encontra taxas de volatilidade bastante baixas, compatíveis com as existentes em democracias consideradas maduras. Além disso, Peres detecta sinais de que a volatilidade tanto partidária quanto ideológica estaria se reduzindo, evidência de que estaria em marcha um processo de institucionalização do sistema partidário brasileiro, ao contrário do que previam os reformistas.

Além de seu trabalho empírico, Peres apresenta uma interpretação benigna para o viés consensualista que ele admite existir no sistema político partidário brasileiro. Não foi um erro de engenharia institucional, argumenta ele. Foi uma construção deliberada e politicamente legitima, pois foi implementada por parlamentares democraticamente eleitos para a Assembléia Constituinte, cujo objetivo foi induzir os atores políticos à negociação e à moderação. Por conta da fragmentação do poder, a busca negociada do consenso é mandatória.

Braga (2006) chega a conclusões semelhantes às de Peres. Ela trabalha com uma gama bastante ampla de dados abrangendo o desempenho dos partidos nas eleições para presidente, governador, deputados federal e estadual nos estados e na totalidade dos municípios brasileiros entre 1990 e 2002. Seus cálculos sobre a volatilidade do voto indicam variabilidade acentuada mas decrescente. Ao analisar a evolução da votação dos partidos nos estados e municípios, Braga identifica a tendência de nacionalização, de fortalecimento das principais legendas e de consolidação das diferenças ideológicas entre elas. Segundo sua análise, a tendência centrífuga à qual o sistema partidário brasileiro estaria teoricamente submetido por conta da combinação entre eleição majoritária para cargos executivos e proporcional com lista aberta para deputados em um país federativo não prevaleceu porque a lógica das disputas majoritárias se impôs e organizou a atuação dos partidos. De acordo com 
Braga, a coincidência entre as eleições majoritárias e proporcionais nacionais a partir de 1994 seria um elemento importante para o acoplamento entre esses dois tipos de eleição.

Além disso, ao correlacionar o desempenho dos partidos nos municípios nas eleições presidenciais, para os governos de estados, prefeitos, vereadores, deputados e senadores, Braga encontrou resultados estaticamente significativos que indicam convergência entre essas variáveis. ${ }^{22}$ A correlação positiva é mais acentuada no caso das eleições coincidentes (presidente, governador, senador e deputados). Seus exercícios mostram ainda que a eleição para governador é a que mais se correlaciona com as de senador e deputados, embora a disputa presidencial seja a que mais condiciona os arranjos (coligações) eleitorais.

Portanto, na avaliação de Braga, o sistema partidário brasileiro, tal como teria ocorrido no final do período 45-64 (Soares 1974, Souza 1976 e Lavareda 1991) estaria caminhando para a institucionalização e não para a desagregação.

\begin{abstract}
“Assim, verifica-se o que já ocorria em 1945, ou seja, o papel para as eleições majoritárias. A despeito de agora vigorar um sistema majoritário de dois turnos (que, teoricamente, facilitaria a pluralização das forças políticas), a lógica prevalecente é similar àquela de turno único, que operava no período de 45-64, dado que é no primeiro turno que se estabelecem as alianças e coligações que combinam as eleições majoritárias com as proporcionais. (...) Todavia, diferente do período anterior, a simultaneidade da eleição presidencial com as demais, de 1994 em diante, ensejou um contexto de maior complexidade, no qual os partidos políticos são incentivados a coordenarem, ao mesmo tempo, estratégias eleitorais nos cenários estaduais e nacional. A combinação desse calendário eleitoral com um sistema proporcional, que opera favorecendo os grandes partidos, tem funcionado na direção de um processo de concentração das forças partidárias com real poder eleitoral e parlamentar" (Braga 2006: 105).
\end{abstract}

A respeito do elevado percentual de migração partidária, fato comumente apontado como prova da fragilidade dos partidos políticos no Brasil, Freitas (2008a) apresenta uma avaliação menos negativa do fenômeno. Para começar, ela argumenta que, se os partidos fossem mesmo irrelevantes, não faria sentido trocar de legenda. Seria indiferente para o parlamentar permanecer ou não no partido pelo qual foi eleito. Freitas renega ainda a ideia de que a principal razão que incentiva os parlamentares a trocar de partido seja a intenção de se aproximar do governo. Para chegar a essa conclusão, Freitas divide os partidos no Congresso em três categorias: coalizão (partidos que fazem parte da base governista e indicaram ministros), satélites (partidos que apesar de não fazerem oficialmente parte da base

\footnotetext{
${ }^{22}$ Almeida e Carneiro (2008) chegam a conclusão semelhante também a partir da análise e do tratamento estatístico dos dados das eleições nacionais, estaduais e municipais realizadas entre 1994 e 2000 . Um elemento interessante no trabalho deles é encadeamento estatístico temporal dessas eleições, o que lhes permite explorar a hipótese da existência de conexão e coerência entre essas três esferas da disputa eleitoral no Brasil.
} 
governista exibem taxas expressivas de votações - cerca de $85 \%$ - alinhadas com a orientação da liderança do governo) e oposição. Ao levar em conta também os partidos satélites, Freitas não detecta no conjunto das trocas partidárias ocorridas entre 1995 e 2007 preponderância de um movimento em direção à coalizão governista.

\begin{abstract}
"Basicamente, quando olhamos o apanhado das quatro legislaturas não se observa um movimento constante em nenhuma das categorias. Não podemos afirmar, portanto, que os parlamentares troquem de legenda procurando a coalizão do governo. Mesmo nas legislaturas 2003 e 2007, as trocas de legenda entre partidos de fora da coalizão, ou seja, os de oposição ou satélites, para o governo, é da ordem de $32 \%$ e $25 \%$, respectivamente. Não é possível explicar a migração partidária explicando apenas $30 \%$ dos casos, e em duas legislaturas apenas" (Freitas 2008a: 53).
\end{abstract}

Qual seria então a explicação para as trocas de partido? Segundo ela, do ponto de vista do parlamentar, há motivações diversas para trocar de partido. "Enquanto alguns parlamentares trocaram de partido pensando na arena parlamentar, outros trocaram de partido pensando na arena eleitoral, outros, por sua vez, se preocupam com a correlação de forças em seus Estados" (Ibidem: 58). Mas o que Freitas apresenta de mais inovador em sua dissertação é analisar a migração partidária não do ponto de vista dos parlamentares, mas sim dos partidos. "Se quisermos explicar a migração partidária não podemos manter o foco no migrante, a pergunta não pode ser o que este busca individualmente, mas sim, o que a migração partidária revela sobre o sistema político, sobre o comportamento dos partidos e sobre as estratégias a disposição dos atores que atuam neste sistema" (Ibidem: 59). Com esse foco, suas conclusões são as seguintes:

\footnotetext{
“Se o que importa é obter acesso a recursos e reeleição, deve-se reconhecer que estes passam, necessariamente, pelos partidos. Ou seja, os parâmetros para o cálculo individual são dados pelos partidos. O que me leva a crer que os partidos políticos é que são o motor das trocas de legenda, e não os parlamentares individualmente". (I bidem: 18)

\begin{abstract}
"Assim, ainda que não dê conta da explicação da totalidade do fenômeno, a mudança no foco da análise da migração partidária possibilita que afinemos nosso entendimento do papel dos partidos políticos a cada troca de legenda. Como vimos, diferentemente do que imaginamos, as trocas de legenda não são reflexo da fragilidade dos partidos políticos brasileiros, mas uma forma diferente que estes encontraram para se organizar". (I bidem: 91)
\end{abstract}

Em outro texto, Freitas (2008b) analisa a migração partidária do ponto de vista da representação. Freitas questiona a tese de que ao deixar o partido pelo qual foi eleito e se transferir para outra legenda o parlamentar estaria violando o nexo representativo que 
estabeleceu com seu eleitor. De acordo com ela, não é possível, a priori, estabelecer no contexto brasileiro, onde vigora o sistema de lista aberta, se o elo representativo mais forte está estabelecido com o partido ou com o próprio parlamentar. Dessa forma não se poderia afirmar que o troca-troca partidário debilita a representatividade do sistema partidário brasileiro.

Ainda sobre a migração partidária, vale destacar uma observação qualitativa de Jairo Nicolau (1996) a respeito do fenômeno. Ao contrário de Freitas, Nicolau considera que a troca de partidos é indicativa da fraqueza institucional dos partidos brasileiros. No entanto, ele afirma que a elevada mobilidade dos parlamentares tem o seu lado funcional para o nosso presidencialismo:

\begin{abstract}
"A intensa troca de legenda é sem dúvida um sinal da pouca institucionalização dos partidos brasileiros. Porém é possível avaliar seus efeitos como funcionais para a operação do presidencialismo brasileiro, já que facilitam o processo de ampliação de sustentação parlamentar do Executivo. Dito de outra maneira, numa situação inversa, em que se combinassem um quadro partidário de alta fragmentação, governos minoritários e partidos inflexíveis, provavelmente a formação de uma base parlamentar seria dificultada". (Nicolau 1996: 98)
\end{abstract}

\title{
I.3 - Estado e partidos políticos no Brasil
}

Ressaltar a importância da relação entre o Estado e os partidos políticos pode ser uma novidade na Europa, mas não no Brasil. Não pode haver dúvida quanto a isso em um país onde o Estado, em passado não muito remoto, de 1930 a 1979, extinguiu partidos políticos, criou outros, proscreveu legendas de esquerda e limitou a disputa partidária a dois partidos entre 1965 e 1979.

Não obstante, a literatura brasileira a respeito dos partidos políticos não tem dado muita atenção a essa questão. Talvez porque, historicamente, a conexão entre Estado e partidos políticos no Brasil seja tão evidente. Como mostramos na seção anterior, o que mais mobilizou o debate recente sobre partidos no Brasil foi a questão da institucionalização do sistema partidário.

A relação entre Estado e partidos no Brasil aparece de forma diluída em Faoro (1953). Isto é, não é um tópico específico do autor que trata a presença dominadora do Estado como algo perene e espraiado ao longo de toda tessitura econômica, social e política do país, desde a sua colonização, ou até antes disso, visto que as raízes da supremacia estatista são, na visão de Faoro, ainda mais remotas. Foi gestada na formação do estado nacional português a partir da Revolução de Avis. 
A interação entre Estado e partidos no Brasil tampouco é o tema central em Schwartzman (1982). O tópico fundamental de Bases do Autoritarismo Brasileiro é a relação entre o Estado e a sociedade no Brasil, contemplada a partir de um ponto de vista histórico analítico. Mas, sob esse pano de fundo mais amplo, Schwartzman (1982), ao contrário de Faoro, dedica algumas páginas de seu livro especificamente à questão a partir da análise das características principais legendas do período 45-64.

Tal como Faoro, Schwartzman considera que a história brasileira desde a Colônia está profundamente marcada pela preponderância do Estado em relação à sociedade e pela débil fronteira entre as esferas pública e privada. Em Schwartzman, o padrão histórico da relação entre Estado e sociedade é marcado pela existência de um “Estado hipertrofiado, burocratizado e ineficiente, ligado simbioticamente a uma sociedade debilitada, dependente e alienada" (Schwartzman 1982: 26). Ao invés do "patrimonialismo" de Faoro, Schwartzman prefere chamar esse regime de dominação estatal de "neopatrimonialismo", para diferenciá-lo do patrimonialismo clássico, conforme definido por Weber, o qual se aplicaria com mais justeza a sociedades arcaicas e não capitalistas.

Schwartzman considera que "a sociedade civil brasileira tem sido incapaz de criar um sistema político em condições de se contrapor efetivamente ao peso avassalador do poder central ou contrabalançá-lo". (Schwartzman 1988: 1). A predominância do Estado (neo)patrimonialista não é tão indelével em Schwartzman quanto em Faoro, a quem ele critica justamente pela tendência de "atribuir ao patrimonialismo brasileiro um caráter absoluto e imutável no tempo" (Ibidem: 70). Contudo, para Schwartzman, o neopatrimonialismo é uma característica duradoura e importante da relação Estado e sociedade no Brasil. É este regime de dominação política que sustenta certa tendência ao autoritarismo político no Brasil, o qual, por conta disso, "não é um fenômeno passageiro, mas tem raízes profundas e implicações que não se desfazem por meros arranjos institucionais". (Ibidem: 14).

Uma característica importante do neopatrimonialismo é o predomínio da cooptação política sobre a representação política. Cooptação política "refere-se a um sistema de participação política débil, dependente, controlado hierarquicamente, de cima para baixo", no qual "a participação política deixa de ser um direito e torna-se um benefício outorgado, em princípio revogável". Nessa relação, que "tende a predominar em contextos em que estruturas governamentais fortes e bem-estabelecidas antecedem historicamente os esforços de mobilização política de grupos sociais" (I bidem: 37), como é o caso do Brasil, os constituintes se transformam em clientes.

É nesse contexto, de tensão entre forças de cooptação e de representação política, que Schwartzman (1982) situa os partidos políticos de 45 a 64. Segundo a avaliação do autor, nem PSD nem PTB, contumazes aliados e principais partidos durante esse período, tinham como 
base de atuação e de legitimação política a representação de interesses da sociedade. Ao contrário, PSD e PTB foram:

\begin{abstract}
“partidos de 'posições', partidos de governo, que funcionavam combinando recursos de poder com capacidade de cooptar as lideranças locais e sindicatos ascendentes. Em ambos os partidos, o poder eleitoral derivava do acesso a posições governamentais e centros de decisão. (...) Eram partidos que dependiam essencialmente, para subsistir, da companhia do poder, e que se desagregaram tão logo perderam o controle do Estado". (I bidem 1982: 136)
\end{abstract}

A eleição de Jânio Quadros e de João Goulart em 1960 é apresentada por Schwartzman como o evento que rompe os sistemas de cooptação assentados na aliança entre PSD e PTB. De acordo com a interpretação do autor, "o sistema eleitoral, baseado na cooptação de líderes políticos, no paternalismo e no isolamento político do centro econômico [São Paulo] e dos núcleos urbanos não resistiu ao crescimento da mobilização e à nacionalização da política, que fizeram do peso de São Paulo o fator decisivo da vitória" (Ibidem 147). Ainda de acordo com a avaliação de Schwartzman, a radicalização das posições trabalhistas durante o governo João Goulart foi uma tentativa de reconstrução do sistema de cooptação por meio da mobilização das massas urbanas. Contudo, a tentativa fracassou "por falta de apoio econômico, militar e internacional", o que resultou na "restrição forçada da participação política [golpe de 1964], concentrando o poder nas mãos do Executivo e retirando-o do processo eleitoral" (Idem I bidem). Assim, na avaliação de Schwartzman, a lógica predominante da atuação partidária na Segunda República foi a da cooptação e não a da representação.

A interação entre Estado e partidos políticos no Brasil aparece também em Meneguello (1998), em livro derivado de sua tese de doutorado no qual ela estuda a formação dos ministérios nos primeiros governos pós-redemocratização. É interessante assinalar que, na parte teórica de seu trabalho, ela aborda o modelo de partido cartel elaborado por Katz e Mair, naquele momento uma quase novidade na literatura internacional sobre partidos.

No livro, Meneguello revê a sua avaliação negativa a respeito do sistema partidário brasileiro exposta em Lamounier e Meneguello (1986). Segundo ela, a partir do governo Sarney, os partidos voltaram a exercer papel central na ocupação do espaço político decisório no governo federal, sendo isso um passo adiante no sentido da consolidação do sistema partidário brasileiro. "O período pós-85 traz importantes alterações no comportamento partidário comparado ao período anterior, produzidas pela sua relação com o Estado. A reintrodução do acesso às instâncias de decisão através de eleições em todos os níveis e a dinâmica de ocupação de cargos públicos pelos partidos, sobretudo a reintrodução do controle político na equipe ministerial, constitui-se um campo importante para a produção de recursos de organização às agremiações". (Meneguello 1998: 70) 
Mas a principal contribuição para o estudo da relação entre Estado e partidos no Brasil foi dada por Maria do Carmo Campello de Souza (1976) em Estado e Partidos Políticos no Brasil (1930 a 1964), que, ainda hoje, permanece como uma obra de referência sobre esse tema no Brasil

O arcabouço teórico, os objetivos o tema e até a forma e estilo de argumentação de Campello de Souza são bastante diferentes dos de Katz e Mair, até porque praticamente vinte anos separam a obra dela da dos dois autores. Contudo, têm como importante ponto comum a ênfase à relação entre os partidos e o Estado e a crítica à escassa importância que os cientistas políticos costumam dar a essa dimensão da atividade partidária.

Souza destaca essa característica dos estudos sobre os partidos no Brasil. Segundo ela, referindo-se à produção acadêmica brasileira, "pouca atenção se tem dado às relações entre o sistema partidário e o Estado, entendido este, como dissemos, em sua qualidade de locus para a tomada e implementação de decisões. Assim é que os estudos existentes sobre as bases sociais ou sobre a mecânica eleitoral e institucional dos partidos desconsideram por completo a burocracia estatal e o processo de policy making". (Souza 1976: 28).

Ou ainda: "a literatura tem tido a tendência básica de focalizar os partidos políticos apenas como produto da sociedade atuando sobre o Estado, e não na direção inversa, também válida". (I bidem: 29)

Assim, um dos pontos de partida de Souza é dissecar a atividade partidária tanto "por sua função representativa quanto pela função governativa" (Ibidem: 31). "Em resumo, pois, nosso objetivo é o exame do sistema partidário em relação ao Estado brasileiro. Contrastando com o modelo implícito na literatura corrente, que vê os partidos em termos da sociedade atuando sobre o Estado, queremos colocar aqui o enfoque inverso: a estrutura estatal como condicionante da formação, evolução e atuação dos partidos políticos". (Ibidem: 42)

A partir dessa proposta, Souza traça a evolução do sistema partidário brasileiro de 1930 a 1964. Mostra que o sentimento antipartidário presente em largas parcelas da intelectualidade brasileira, forjado nas últimas décadas do século XIX e nas primeiras do século XX, persistiu até 1964. Naturalmente, foi mais marcante durante o Estado Novo, mas continuou presente no interregno democrático de 45 a 64. Aliás, uma de suas conclusões é que, apesar de o regime de 45 ter representado uma ruptura com o Estado Novo em vários aspectos institucionais, afinal passou-se de um regime quase totalitário à democracia - ou à quase democracia - , em outros houve continuidades marcantes, ou, como ela diz, "pelo menos mudança claramente condicionada e dirigida" (Ibidem: 105). A observação se aplica ao sistema partidário que foi criado a partir da deposição de Getúlio Vargas, no qual os dois principais partidos - o PTB e o PSD - foram gestados no Palácio do Catete. Como se sabe, o 
PSD constituiu-se a partir da estrutura das interventorias estaduais, o que estendeu ao novo regime o poder da máquina burocrática e política getulista criada durante o Estado Novo. Ao PTB, em contrapartida, coube cuidar do legado popular trabalhista de Getúlio Vargas assentado na estrutura sindical corporativa. Souza argumenta ainda que a lei que regulamentou as eleições e a atividade partidária - o Código Eleitoral, ou como também ficou conhecida, a Lei Agamenon, referência ao ministro da Justiça Agamenon Magalhães - foi escrita de maneira a dar aos grupos getulistas, notadamente ao PSD, condições de conquistar a maioria das cadeiras do Congresso, pelo menos na primeira legislatura pós Estado Novo. Outros fatores, como a emergência do getulismo e a adoção de mecanismos que preservavam o caráter centralizado dos poderes no Executivo, também são citados como elementos de continuidade.

Dessa forma, conclui Souza, "a maneira pela qual se deu no Brasil esse fortalecimento [do Executivo] foi a preservação da extensa margem de arbítrio consagrada após 1930, particularmente sob o Estado Novo. (...) A concentração de poderes se manteve, assim, rigorosamente em linha com a ideologia da década anterior, cuja pedra angular havia sido, como vimos, a exclusão de qualquer projeto institucional de governo partidário". (Ibidem: 136)

A explicação de Souza para a ruptura institucional de 1964 envolve justamente o conflito entre o governo partidário e as instituições - e mesmo certa ideologia, que Bolívar Lamounier, citado pela autora, denomina de "ideologia de Estado"23 - favoráveis à centralidade do poder estatal.

Ao mesmo tempo, Souza argumenta que o sistema partidário brasileiro, ao contrário da avaliação predominante, não estava se desestruturando. Ela admite que havia forças que atuavam no sentido de desalinhar o sistema partidário. Porém, o movimento predominante na sua avaliação era na verdade de realinhamento, caracterizado pelo avanço do PTB nas cidades médias e dos partidos pequenos e mais ideológicos nos centros urbanos mais importantes. Esses movimentos foram acompanhados pela crescente interiorização da base eleitoral do PSD e do encolhimento da UDN, que se volta cada vez mais aos extratos médios urbanos. ${ }^{24}$ Assim, caso esse processo não tivesse sido subitamente interrompido pelo golpe militar, Souza avalia que poderia ter se estabelecido no Brasil um efetivo regime de governo partidário. Contudo, o dilema fundamental - "Estado sem partidos ou governo partidário" (Ibidem: 140) - que se estabeleceu nos momentos que antecederam o golpe militar e que foi, de acordo com a interpretação dela, fator decisivo para a eclosão da crise de 64, resolveu-se a favor do Estado

\footnotetext{
${ }^{23}$ Ver Lamounier (1985).

${ }^{24}$ Lavareda (1991) e Soares (1974) também entendem que o sistema partidário caminhava para o realinhamento e não para a desestruturação.
} 
sem partido, ou quase sem partido. Para resumir, a hipótese defendida pela autora é que "o caráter crítico da conjuntura [pré-golpe militar] deriva do simultâneo fortalecimento do Estado e do sistema partidário, colocando, de maneira nada remota, o dilema Estado sem partidos ou governo partidário" (Idem).

Além da ênfase dada à relação entre Estado e partidos políticos, outra razão para discutirmos nesta dissertação a obra de Souza é que ela trata da trajetória do PSD e UDN, precursores mais longínquos do PDS e do PFL. Apoiada em dados de Soares (1971), Souza mostra que, de 1945 a 1964, o PSD e a UDN perderam espaço para o PTB. ${ }^{25}$ Este, tradicionalmente forte nos grandes centros urbanos dos estados mais desenvolvidos, passou a crescer também nos estados menos desenvolvidos e nas cidades médias, redutos tradicionais do PSD e, em menor escala, da UDN. Tal processo de realinhamento do sistema partidário foi interrompido pelo golpe militar, mas Souza avalia que as tendências visíveis pré-64 indicam que a UDN "passaria a depender cada vez mais dos estratos médios e altos das cidades médias e das capitais, compensando, em parte, a escassez numérica dessa base com a regularidade de sua participação eleitoral e com sua fidelidade às bandeiras clássicas do udenismo" (Ibidem: 145). Quanto ao PSD, “ostra incrustada no casco da nau do Estado"26, é um partido que ela classifica como "camaleão rural-burocrático" (I bidem: 146). Isto é, tinha como fontes de poder a proximidade com o Estado e, ao mesmo tempo, o domínio político dos grotões do interior. A ascensão do PTB ao poder nacional com João Goulart e o avanço dos trabalhistas nas cidades médias, prenúncio de que poderiam chegar também aos grotões, provavelmente, diz a autora, estimulariam o PSD a se voltar ainda mais a suas bases ruralistas.

O golpe militar, apoiado por grande parte do PSD e da UDN, resolveu os impasses udenistas e pessedistas. O PTB foi dizimado e, apesar de os líderes mais proeminentes do PSD e da UDN - Juscelino Kubitschek e Carlos Lacerda, respectivamente - terem sido posteriormente alijados do jogo político pelos militares, a maioria dos políticos desses dois partidos acabou se abrigando na Arena, de cuja costela saiu o PDS e, depois, o PFL. Nessa perspectiva, pode-se dizer que tanto o vínculo com a máquina estatal quanto a força político eleitoral nos grotões são características quase atávicas do PFL que lhe foram legadas por seus antecessores partidários: o PSD e a UDN.

\section{I.4 - O PFL como partido cartel}

Retornando a Katz e Mair e ao partido cartel, é importante ressaltar que o vínculo entre Estado e partidos no Brasil, ao menos até a redemocratização pós regime militar, foi

\footnotetext{
${ }^{25}$ Essa tese contudo é contestada por Lima Júnior (1983), segundo quem, a análise ampliada do sistema partidário brasileiro, levando em conta também o cenário político e eleitoral que se desenrolava nos estados, não permite dizer que os partidos conservadores seriam destronados do poder pelo PTB.

${ }^{26}$ Frase de editorial do jornal O Estado de S. Paulo de 12/10/1963, citada por Souza (1976: 145-146).
} 
qualitativamente diferente da existente nos países que serviram de base para eles desenvolverem a tese dos partidos cartel. Aqui, a característica mais importante dessa relação teve direção inversa da destacada por Katz e Mair. Não foram os partidos que assumiram o controle da máquina estatal e submeteram o Estado a seus interesses. Como destaca Souza (1976), foi o Estado que, durante boa parte de nossa história no século passado, se sobrepôs aos partidos.

É somente a partir do fim do regime militar e da promulgação da Constituição de 1988 que a relação Estado e partidos políticos adquire dinâmica semelhante à destacada por Katz e Mair, conforme destacou Meneguello (1998). Por exemplo, a Constituição de 1988 adotou elementos apontados por Katz e Mair como indicadores da cartelização dos partidos. Destacamos dois deles, talvez os mais fundamentais: o financiamento público aos partidos por intermédio do fundo partidário e a garantia de acesso gratuito aos meios de comunicação de massa (rádio e TV) para propaganda partidária e eleitoral (Constituição Federal, Art. $17 \S$ 3ㅇ). ${ }^{27}$

Tabela I.1: Ministérios ocupados pelo PFL*

\begin{tabular}{|l|c|}
\hline \multicolumn{1}{|c|}{ Presidentes } & Ministros \\
\hline José Sarney & 7 \\
\hline Fernando Collor de Mello & 4 \\
\hline Itamar Franco & 3 \\
\hline $\begin{array}{l}\text { Fernando Henrique Cardoso (primeiro } \\
\text { mandato) }\end{array}$ & 4 \\
\hline $\begin{array}{l}\text { Fernando Henrique Cardoso (segundo } \\
\text { mandato) }\end{array}$ & 3 \\
\hline
\end{tabular}

Fontes: Meneguello (1998) e arquivo pessoal.

* Número máximo de ministérios ocupados pelo PFL em cada governo.

Esse foi justamente o momento no qual o recém criado PFL firmou-se como um dos partidos mais fortes do país. Naturalmente, os benefícios citados acima não foram abrigados na Constituição graças apenas ao PFL. Foi obra de todos, ou pelo menos da maioria, dos partidos representados na Assembléia Constituinte. É um fato consoante à teoria de Katz e Mair que, como vimos, dão a essa ação conjunta dos partidos o caráter de conluio, característica que serve de principal justificativa para a denominação "partidos cartel".

Mas o PFL, em particular, pode ser qualificado como exemplo próximo de partido cartel no Brasil, pelo menos entre 1985 e 2002, dada a sua proximidade com o governo federal. 0

\footnotetext{
${ }^{27}$ O referido parágrafo estabelece o seguinte: “Os partidos políticos têm direito a recursos do fundo partidário e acesso gratuito ao rádio e à televisão, na forma da lei”.
} 
PFL participou de todos os ministérios formados durante esse período, como mostra a Tabela I.1. Foi o único a fazê-lo. O PMDB, que formou com o PFL a Aliança Democrática, coalizão responsável pela eleição de Tancredo Neves, não teve representantes no ministério de Fernando Collor de Mello. De 1985 a 1995, as pastas mais frequentemente ocupadas pelo PFL foram as de Irrigação, Comunicação, Educação e Minas e Energia (Meneguello 1998: 223224). No governo Fernando Henrique Cardoso, as principais áreas comandadas pelo PFL foram Minas e Energia e Previdência Social.

A participação do PFL nos governos Sarney, Collor de Mello e Fernando Henrique Cardoso foi uma decorrência natural do apoio que os pefelistas deram a esses presidentes antes mesmo deles serem eleitos. O PFL foi peça fundamental na eleição de Tancredo Neves e tinha grande proximidade com José Sarney, um dos líderes da dissidência do PDS que resultou na criação do PFL. A filiação de Sarney ao PMDB naquele momento deveu-se apenas à legislação vigente, a qual exigia que os candidatos a presidente e vice-presidente pertencessem ao mesmo partido. Com relação a Collor, embora o PFL tenha lançado um candidato próprio - Aureliano Chaves - parcelas expressivas do partido o apoiaram logo no primeiro turno. A candidatura de Aureliano Chaves foi um retumbante fracasso nas urnas. Obteve apenas $0,9 \%$ dos votos válidos. A adesão dos pefelistas a Collor foi integral no segundo turno. Já em relação ao governo Itamar Franco, o PFL se agregou à ampla coligação que apoiou o vice-presidente após ele assumir o comando do país em decorrência do impeachment de Fernando Collor de Mello. Mas os setores do governo que apoiaram Collor até o impeachment - basicamente os ligados a Jorge Bornhausen e a Antônio Carlos Magalhães ficaram de fora do governo Itamar. No final do mandato de Itamar, o PFL ocupava apenas um ministério. A aliança com Fernando Henrique Cardoso, por sua vez, foi mais forte e sólida. O PFL participou das coligações que elegeram Fernando Henrique Cardoso em 1994 e em 1998 sendo responsável pela indicação do vice-presidente: Marco Maciel nas duas oportunidades. Portanto, se considerarmos que PSD, UDN, Arena e PDS foram os antecessores do PFL, podemos dizer que a linhagem política pefelista esteve no poder praticamente desde 1945.

Segundo análise de Tarouco (1999: 86-90), a participação no governo federal foi fundamental para sustentar a força do partido entre 1985 e 2002. Durante esses anos, o PFL foi, na maior parte do tempo, o segundo maior partido do Congresso, abaixo apenas do PMDB. A presença no governo e no Congresso foram as principais fontes de poder do PFL. Foram fontes de poder interligadas que se auto reforçaram ao longo do tempo. A capacidade de eleger bancadas expressivas na Câmara dos Deputados e no Senado proporcionou ao PFL força para conquistar espaço nos governos em troca de apoio no Congresso. Ao mesmo tempo, o acesso à máquina estatal e às benesses que os cargos nos vários escalões do governo lhe propiciavam (patronagem e maior capacidade de atender demandas de suas bases eleitorais 
por verbas transferidas pelo governo federal) dava ao PFL recursos fundamentais para eleger um bom número de parlamentares.

Assim, pode-se afirmar que o PFL exibe características que o aproximam do perfil de partido cartel definido por Katz e Mair. Como diz Tarouco, “a 'vocação governista' do PFL, que parece ser unanimidade tanto na imprensa quanto entre os analistas, consiste numa estratégia calculada de obtenção de recursos políticos através de uma estreita associação com o Estado. A intimidade do PFL com o poder corresponde à aproximação entre os partidos políticos e o Estado identificada por Peter Mair como as novas bases do desenvolvimento das organizações partidárias". (1999: 102)

Além da relação próxima com o Estado, outro fator que favorece a classificação do PFL como partido cartel é a predominância de sua face party in the central office e, principalmente, party in the public office sobre o party on the ground. Como indica a frase de Marco Maciel destacada na epígrafe deste capítulo, o PFL sempre careceu de uma base partidária sólida. Isto é, de um grupo coeso de militantes e simpatizantes - ou adeptos, como os chamava Duverger - capaz de interferir ativamente nas decisões partidárias e de definir, de baixo para cima, diretrizes para a atuação do partido.

Essa era a situação do PFL até 2002, quando ocorreu o evento que alterou drasticamente a situação do partido: a vitória de Lula na eleição de 2002 e a consequente chegada do PT ao poder. Assim, pela primeira vez desde a sua criação, o PFL passou para a oposição e perdeu acesso ao poder federal.

Do ponto de vista da discussão teórica apresentada neste capítulo, a ida para a oposição e a consequente busca de novas bases partidárias podem ser descritas como a tentativa de passar de um partido cartel para um partido do tipo catch-all que, a partir da classe média, ambicionava se transformar numa versão brasileira do PP espanhol ou do PSD português.

Ou, retomando o modelo de Wolinetz (2002), podemos dizer que a orientação officeseeking é a que melhor se adapta à fase governista do PFL. Na descrição de Wolinetz,

\footnotetext{
"office-seeking parties seek either to hold power alone, or more realistically to share power with others - either for the purposes of survival, or to act as a stabilizer or balance within the system or, more likely, to gain access to patronage. An office-seeking party should avoid policy commitments which might make it undesirable as a coalition partner and skew electoral strategies, such as attacking prospective partners too fiercely, which would make coalitions impossible. The aim - defined in the context of a well-stablished party system would be to win enough votes to ensure inclusion in coalitions". (Wolinetz 2002: 2254-2255)
} 
É uma descrição que se ajusta bem à análise feita por Tarouco (1999) a respeito do modo de atuar do PFL. Segundo Tarouco,

\begin{abstract}
“o PFL vem se firmando no sistema político brasileiro como um partido fundamentalmente parlamentar e de governo: o seu desempenho eleitoral é claramente maior no Congresso Nacional do que nos executivos estaduais e mesmo municipais e a sua participação no governo federal tem sido constante em todo o período. Estas duas frentes de atuação estão estreitamente relacionadas na medida em que o peso parlamentar do PFL the rende lugar certo no governo e cargos cujo exercício lhe confere recursos políticos conversíveis em dividendos eleitorais. Os retornos eleitorais do PFL se originam mais destes fatores do que da ação junto às bases". (1999: 86)
\end{abstract}

Assim, no esquema proposto por Wolinetz, as duas dimensões privilegiadas pelo PFL antes da ascensão petista ao poder nacional eram o office-seeking e o vote-seeking. Mas a primeira delas era mais importante. O desempenho eleitoral servia com um instrumento, digamos assim, para garantir ao partido condições para pleitear espaço na base governista, mesmo nas ocasiões em que não fez parte da coligação vitoriosa na eleição, como foi o caso do pleito de 1989, vencido por Collor de Mello. Quando o PFL foi alijado do poder federal em decorrência da vitória petista de 2002, perdeu abruptamente uma das bases sobre as quais se sustentava o que, mais adiante, afetou também o desempenho do partido nas urnas. Criou-se assim um círculo vicioso do qual a legenda não conseguiu se livrar.

Alijado do poder, o partido tentou se reciclar. Usando o esquema proposto por Wolinetz, podemos dizer que o surgimento do DEM foi uma tentativa de reforçar a faceta vote-seeking do partido buscando uma nova base, formada pelos extratos médios da população urbana das médias e grandes cidades. Assim, pode-se dizer que, na passagem do PFL para DEM, o partido buscou se reformular migrando da combinação office e vote-seeking para vote e policyseeking.

O DEM, contudo, ao menos até o momento, não logrou avançar em nenhuma dessas duas dimensões. Não atraiu uma nova base de eleitores, nem conseguiu estruturar uma linha programática coerente e sólida, capaz de convencer a classe média a apoiá-lo. A ininterrupta perda de políticos para partidos mais próximos ao governo petista, questão que iremos tratar com detalhes no Capítulo 3, é uma evidência de que a condição de partido cartel - ou officeseeking - estava profundamente entranhada no partido.

Os problemas dos partidos cartel apontados por Katz e Mair ajudam a entender a dificuldade do DEM em se conectar com uma nova base eleitoral. Como vimos, um obstáculo no caminho dos partidos cartel é a desconexão com a sociedade, a sua incapacidade de cumprir adequadamente a função representativa tradicionalmente associada aos partidos 
políticos. Parece ter sido o caso do PFL pós refundação. Quando precisou estabelecer laços de fidelidade com um novo tipo de eleitor, faltaram-Ihe canais de acesso e legitimidade. Incapaz de representar qualquer segmento relevante da sociedade e de restabelecer o acesso à máquina do governo federal, o partido mergulhou em uma crise que pode até levá-lo à extinção definitiva.

Nesse sentido, tinha razão o ex-senador Marco Maciel quando apontava a necessidade de o partido constituir uma base e deixar de ser apenas um partido de quadros. Quando o partido passou para a oposição, essa necessidade se tornou premente. O problema é que, como discutimos neste capítulo, estabelecer conexões sólidas com segmentos sociais não é uma tarefa fácil para a maioria dos partidos políticos contemporâneos. Para o PFL, mesmo após a refundação e a troca de nome, foi uma tarefa, até o momento, impossível. 


\section{II - A refundação do PFL}

Completado o processo de implantação da democracia plena no Brasil, assim como a Frente Liberal, de 1984, se transformou em Partido da Frente Liberal em janeiro de 1985, agora o PFL, estabelecida uma nova realidade brasileira e a imperiosa necessidade de rejuvenescimento de seus quadros e líderes, transforma-se em Democratas.

Discurso de Jorge Bornhausen na convenção que criou o Democratas $(28 / 03 / 2007)$

Em 28 de março de 2007, a Executiva Nacional do PFL aprovou por unanimidade a troca de nome do partido. Saiu de cena o Partido da Frente Liberal e entrou o Democratas, ou DEM, na forma abreviada pela qual passou a ser tratado mais comumente.

Não foi apenas uma troca de nome. Pelo menos não para a cúpula do partido. Para os dirigentes do ex-PFL, foi o ponto de chegada de um processo de "refundação" da legenda que, segundo documentos do partido, teve início em 2004.

Concomitantemente à adoção da nova denominação, houve mudanças no comando do partido. O ex-senador Jorge Bornhausen, então com 69 anos, deixou a presidência da agremiação. Em seu lugar assumiu o deputado federal Rodrigo Maia, que tinha 37 anos à época. Outros políticos jovens ocuparam posições de destaque na estrutura partidária, movimento acordado com a maioria dos dirigentes mais experientes do PFL.

O objetivo da "refundação" e da troca de nome e de dirigentes foi reposicionar a legenda no mercado político brasileiro e, principalmente, dar-lhe nova identidade frente ao eleitor. Como reconheceu Bornhausen no documento que sintetizou os princípios do nascente DEM, todo esse processo teve como motivação fundamental transformar a imagem do partido perante o eleitorado.

Na introdução do documento, o ex-presidente do partido, diz que

\footnotetext{
"o PFL foi criado em sintonia com o sentimento do povo brasileiro pela democracia" e sua história "esteve e deve continuar associada ao compromisso da mudança. (...) Não basta que a história e os compromissos com a mudança tenham sido a marca da trajetória partidária. É necessário que a imagem do partido deva ser percebida pela opinião pública. (...) A sintonia com o desejo de mudança na sociedade brasileira e a imagem dela decorrente exige o reposicionamento do PFL que significa um processo natural e necessário de atualização de nosso ideário e a conseqüente renovação do compromisso original de mudança dentro do quadro democrático e frente aos novos desafios da sociedade brasileira". (PFL 2007: 4)
} 
A troca do nome e a tentativa de dar nova identidade à sigla foram amparadas por uma pesquisa de opinião pública conduzida pelo cientista político Antônio Lavareda cujos resultados mostraram que a sigla PFL, além de relativamente pouco conhecida, ainda estava associada de maneira negativa ao regime militar e carregava o estigma de ser um partido de direita.

Neste capítulo, descreveremos o processo de refundação. A primeira seção abordará a conjuntura política que cercou a refundação. A segunda tratará da dinâmica interna da refundação. Já na terceira seção, apresentaremos os resultados da pesquisa realizada pela $\mathrm{MCl}$ sobre a imagem e a identidade do partido antes da refundação. Por fim, na quarta seção discutiremos aspectos relacionados à escolha do novo nome.

\section{II.1 - O PFL na oposição}

Em 2002, o PT ganhou a eleição presidencial e empurrou o PFL para a oposição. Foi uma grande novidade para os pefelistas. Pela primeira vez em sua história, o PFL ficou distante do governo federal.

Na verdade, o PFL já estava com um pé fora do governo antes mesmo da vitória petista. No começo de 2002, em decorrência do chamado caso Lunus, operação da Polícia Federal que descobriu $R \$ 1,34$ milhão em espécie de origem não declarada em um cofre no escritório político de Roseana Sarney, então pré-candidata do partido à eleição presidencial, o PFL rompeu oficialmente com o governo Fernando Henrique Cardoso. A ampla exposição do dinheiro confiscado pela Polícia Federal nos jornais e na televisão implodiu a candidatura de Roseana Sarney, que abandonou a disputa em 13 de abril, um mês e 13 dias após a operação da Polícia Federal. Antes do caso Lunus, a candidatura Roseana Sarney evoluía bem. Segundo números do Datafolha, seu percentual de intenção de voto passou de $12 \%$ para $23 \%$ entre setembro de 2001 e fevereiro de 2002, quando estava apenas 3 pontos atrás de Lula.

A cúpula do partido acusou o Palácio do Planalto de ter usado a Polícia Federal para atingir sua pré-candidata a fim de favorecer o candidato tucano José Serra que, naquele momento, já havia se firmado como o nome governista para disputar a sucessão de Fernando Henrique Cardoso. Em 7 de março de 2002, o partido aprovou resolução que obrigou os ministros pefelistas a deixarem seus cargos. Devido às características particulares de seu cargo, foi dado tratamento diferenciado ao vice-presidente Marco Maciel. Ele continuou na vice-presidência e, até o final de seu mandato, manteve boas relações pessoais e políticas com o presidente Fernando Henrique. 
Rompido com o PSDB e sem dispor de um nome competitivo para apresentar como candidato próprio, o PFL se dividiu. Em 2002, a regra da verticalização, ${ }^{28}$ a qual impedia que partidos que lançassem candidatos à Presidência se aliassem nos estados a partidos rivais na disputa presidencial, ainda estava vigente. Essa regra colaborou para a decisão pefelista de não lançar candidato à Presidência nem apoiar formalmente qualquer um dos candidatos para que pudesse compor com mais liberdade as alianças estaduais.

Assim, na eleição de 2002, algumas alas do partido, mais próximas a Antônio Carlos Magalhães, apoiaram Ciro Gomes. Outras, ligadas a Marco Maciel, se reaproximaram de Serra. Alguns pefelistas chegaram a flertar com a candidatura Garotinho e muitos não apoiaram ninguém. No segundo turno, Antônio Carlos Magalhães anunciou que trabalharia a favor de Lula.

Embora não tenha disputado a eleição presidencial, nem com um candidato próprio nem formalmente aliado a outros presidenciáveis, o PFL teve desempenho razoável na eleição de 2002, conforme mostra a Tabela II.1. Conseguiu manter a condição de um dos principais partidos brasileiros, juntamente com o PT, PMDB e PSDB.

Tabela II .1 - Desempenho do PFL na eleição de 2002*

\begin{tabular}{|l|c|c|c|c|}
\hline & Deputados estaduais & Governadores & Deputados Federais & Senadores \\
\hline PFL & $\mathbf{1 2 2 ( 1 1 , 5 \% )}$ & $\mathbf{4 ( 1 4 , 8 \% )}$ & $\mathbf{8 4 ( 1 6 , 4 \% )}$ & $\mathbf{1 4}(\mathbf{2 5 . 9} \%)$ \\
\hline PT & $147(13,9 \%)$ & $3(11,1 \%)$ & $91(17,7 \%)$ & $10(18,5 \%)$ \\
\hline PMDB & $132(12,5 \%)$ & $5(18,5 \%)$ & $74(14,4 \%)$ & $9(16,7 \%)$ \\
\hline PSDB & $139(13,1 \%)$ & $7(25,9 \%)$ & $71(13,8 \%)$ & $8(14,8 \%)$ \\
\hline
\end{tabular}

* Os valores em parênteses indicam a participação no total de cadeiras em disputa. Fonte: TSE.

Contudo, antes mesmo da posse dos novos parlamentares, o PFL começou a encolher. Entre outubro de 2002 e 01 fevereiro de 2003, data de abertura da nova legislatura, o PFL perdeu nove deputados federais e um senador, todos eles migraram para partidos que compunham a base de apoio ao governo Lula ou estavam em vias de se incorporar a ela.

O governo Lula, por sua vez, começou com o apoio firme de 10 partidos (PT, PSB, PDT, PPS, PC do $B$ e PV, mais à esquerda, e PL, PTB, PMN e PSL, mais à direita) e bom entendimento com o PMDB e o PP. Nas negociações comandadas pelo ex-ministro José Dirceu para a formação do primeiro gabinete de Lula, caberiam ao PMDB dois ministérios. Contudo,

\footnotetext{
${ }^{28}$ A chamada verticalização das eleições foi adotada em decorrência de decisão do Tribunal Superior Eleitoral (TSE) em 26 de fevereiro de 2002, praticamente sete meses antes da eleição presidencial. O TSE tomou como base o princípio constitucional de que os partidos brasileiros devem ter caráter nacional e, dessa forma, na interpretação da maioria dos ministros do TSE, a lógica das alianças para a disputa presidencial deveria se sobrepor aos arranjos eleitorais estaduais. A verticalização foi derrubada em 2006, quando o Congresso aprovou uma emenda constitucional (EMC 52/2006) promulgada em 08 de março a qual deu explicitamente aos partidos ampla liberdade para a composição de coligações em nível federal e nos estados.
} 
nos momentos finais da definição do ministério, Lula vetou o acordo fechado entre o comando do PMDB e José Dirceu, e os pemedebistas ficaram de fora do governo. Somente em 2004, o PMDB passou a integrar o ministério lulista, quando o deputado Eunício Oliveira (CE) e o senador Amir Lando (RO) foram nomeados para os ministérios das Comunicações e Previdência Social, respectivamente. O PP conseguiu o seu ministério apenas em julho de 2005, com Márcio Fortes, nomeado para o ministério das Cidades. Porém, mesmo antes de PMDB e PP serem admitidos no primeiro escalão do governo petista, já se alinhavam com o governo nas votações no Congresso, garantindo à base governista posição majoritária tanto na Câmara quanto no Senado. ${ }^{29}$

Alojados na oposição, PFL e PSDB voltaram a se aproximar. No entanto, a decisão do governo Lula de dar continuidade no essencial à política econômica que vigorou no segundo mandato do governo Fernando Henrique Cardoso (meta de inflação, autonomia operacional do Banco Central, meta de superávit fiscal primário e taxa de câmbio flutuante) e a adoção de uma agenda parlamentar de reformas também próxima da defendida pela administração anterior provocaram perplexidade e alguma confusão nas fileiras oposicionistas. Como se posicionar em relação a propostas do governo Lula que faziam parte da agenda do governo Fernando Henrique Cardoso? Era o dilema de tucanos e pefelistas no Congresso.

A taxação de servidores do governo federal inativos, aposentados ou pensionistas, foi especialmente emblemática do embaralhamento de posições no Congresso no começo da gestão petista. A medida, que havia sido encaminhada diversas vezes ao Congresso durante o governo Fernando Henrique Cardoso e sistematicamente rejeitada, com apoio do PT, foi incluída na proposta de reforma da Previdência Social formulada pelo governo Lula no começo de 2003. A taxação dos inativos era vista pelo mercado financeiro como simbólica da conversão petista à ortodoxia econômica. Se o governo Lula decidiu adotar uma medida contrária aos interesses dos servidores públicos, segmento considerado pró-petista, é porque passou a valorizar fortemente a estabilidade macroeconômica, raciocinavam os agentes do mercado.

No final, a taxação dos inativos somente foi aprovada porque deputados e senadores do PSDB e do PFL votaram a favor da medida. Sem eles, não teria sido possível alcançar o quorum qualificado de três quintos (308 votos) necessário para a aprovação da proposta. ${ }^{30} \mathrm{~A}$ discordância em relação ao conteúdo da reforma da previdência deu início à dissidência que

\footnotetext{
${ }^{29}$ Para a discussão sobre a composição de maiorias no Congresso no chamado “presidencialismo de coalizão” brasileiro, ver Abranches (1988), Meneguello (1998) e Amorim Neto (2006).

${ }^{30}$ A reforma da previdência (PEC 40/2003) foi aprovada em 05 de agosto de 2003 com 358 votos favoráveis. Votaram a favor da PEC 40, 33 deputados do PSDB e 29 do PFL. Sem esses votos, a PEC 40 teria obtido o apoio de apenas 296 deputados e não seria aprovada.
} 
resultou na saída de petistas ligados às correntes mais à esquerda do PT e que fundaram posteriormente o PSOL.

2003, o primeiro ano do PT no governo federal e do PFL na oposição, ficou assim marcado pela manutenção da política econômica anterior e pela promoção de uma agenda de reformas institucionais anteriormente criticada pelos petistas. Foi um ano de ajuste econômico, de contração do PIB e de inflação relativamente alta, mas cadente. Mesmo assim, o governo Lula chegou ao final do ano com uma popularidade relativamente alta, considerando-se as dificuldades econômicas. Segundo o Datafolha, em dezembro de 2003, 42\% da população avaliava o governo Lula como ótimo ou bom. Na oposição, 2003 marcou a estréia de uma dúvida que marcou a atuação oposicionista durante os dois mandatos de Lula: como se opor ao governo petista após este ter replicado, no essencial, a mesma política econômica estabelecida por Fernando Henrique Cardoso a partir de $1999 ?$

Essa, na verdade, foi uma questão que perseguiu mais o PSDB do que o PFL. A maioria dos pefelistas adotou desde o início posição bastante aguerrida contra o governo Lula. A exceção foi o senador Antônio Carlos Magalhães que, entre o segundo turno da eleição de 2002 até o final de 2004, buscou se aproximar do governo Lula. Por conta disso, em setembro de 2004, o deputado Ônix Lorenzoni (PFL-RS), com a anuência do presidente da legenda, senador Jorge Bornhausen, protocolou junto ao comando do partido um pedido de expulsão do senador baiano. O evento que motivou o pedido de expulsão foi a participação de Antônio Carlos Magalhães e de mais sete senadores pefelistas em jantar de confraternização com o presidente Lula. A atitude de Antônio Carlos Magalhães foi considerada por Bornhausen uma afronta ao partido, que comentou o episódio dessa maneira na imprensa em 14 de setembro de 2004: “o encontro retrata a lastimável realidade da política brasileira. De um lado, o comandante José Dirceu e seus comandados, Lula e o ministro Aldo Rebelo, praticando um ato explícito de cooptação. De outro, Antônio Carlos Magalhães oferecendo adesão".

O relacionamento entre Jorge Bornhausen e Antônio Carlos Magalhães sempre foi tumultuado. Antônio Carlos Magalhães não fez parte do grupo que fundou o PFL em 1985, embora também tenha apoiado a eleição de Tancredo Neves contra Paulo Maluf. Ele aderiu ao PFL apenas em 6 de janeiro de 1986, praticamente um ano depois da fundação do partido. Para tanto, obteve de Bornhausen, Marco Maciel, Aureliano Chaves e Guilherme Palmeira, os principais líderes pefelistas naquele momento, a garantia de que teria liberdade de ação dentro da legenda. ${ }^{31}$ A entrada de Antônio Carlos Magalhães no PFL foi descrita dessa maneira por Jorge Bornhausen em entrevista para esta dissertação:

\footnotetext{
${ }^{31}$ Ver Cantanhêde (2001: 46)
} 
“o senador Antônio Carlos Magalhães não foi fundador do partido. Ele permaneceu no PDS. Graças à sua habilidade política e ao seu jogo pessoal, ele negociou o Ministério das Comunicações para ele. Apesar da grande resistência do PMDB, ele entrou no ministério na cota pessoal do Tancredo, negociada por ele. E, portanto, ele não tinha ligação com a fundação do partido. Ele apoiou Andreazza. Após a vitória do Maluf na convenção do PDS, ele procurou o Tancredo para fazer essa negociação política. Quando eu estava na presidência do partido, o presidente José Sarney me chamou e disse 'olha, está na hora de você levar o Antônio Carlos para o PFL'. Eu fui conversar com o Antônio Carlos e ele realmente queria entrar para o PFL, mas exigiu, pela sua força política, que ficasse com o comando do partido. Aí nos tivemos que fazer uma difícil negociação interna. Foi uma negociação dificílima, mas ele entrou no partido, embora sem a posição de comando que almejava". (entrevista ao autor)

A reação mais firme da direção do PFL contra Antônio Carlos Magalhães em 2004 explica-se por duas razões. Primeiro, os dirigentes do partido avaliaram que a posição de Antônio Carlos Magalhães em relação ao presidente Lula atrapalhou o desempenho do partido na eleição municipal, pois transmitiu ao eleitor sinais ambíguos a respeito do PFL. Enquanto a direção pefelista se esforçava para convencer a opinião pública que o partido não era adesista e se opunha ao governo petista, Magalhães era retratado pela imprensa como um aliado de Lula.

Além do mais, naquele momento, a direção do PFL já havia decidido promover a refundação do partido. E, para dar credibilidade às mudanças que atingiriam o partido, considerava fundamental que a legenda se posicionasse de maneira inequívoca como um partido de oposição e afastasse de uma vez por todas a imagem de que o PFL seria um partido fisiológico, pronto a aderir ao governo da hora, qualquer que fosse a ideologia ou projeto para o país.

Tabela II.2 - Desempenho do PFL na eleição de 2004*

\begin{tabular}{|l|c|c|c|}
\hline & Vereadores & Prefeitos & Prefeitos de Capitais \\
\hline PFL & $\mathbf{9 . 6 4 8 ( 1 6 , 0 \% )}$ & $\mathbf{7 8 9 ( 1 4 , 2 \% )}$ & $\mathbf{1}(\mathbf{3 , 8} \%)$ \\
\hline PMDB & $11.372(18,9 \%)$ & $1.060(19,1 \%)$ & $2(7,7 \%)$ \\
\hline PSDB & $8.517(14,1 \%)$ & $871(15,7 \%)$ & $5(19,2 \%)$ \\
\hline PT & $2.485(4,1 \%)$ & $409(7,4 \%)$ & $9(34,6 \%)$ \\
\hline
\end{tabular}

* Os valores em parênteses indicam a participação no total de cadeiras em disputa. Fonte: Nicolau (2010)

Após quase ter sido expulso do PFL, diante do período de crise no qual o governo Lula mergulhou por conta do episódio do "mensalão", Antônio Carlos Magalhães, a partir de 2005, deixou de cortejar a administração petista e se realinhou com a ala mais oposicionista do partido. A postura oposicionista de Antônio Carlos Magalhães se reforçou à medida que se 
aproximava a eleição de 2006 na qual o PT surgia como a principal ameaça à hegemonia carlista na Bahia.

O desempenho do partido na eleição municipal de 2004 reforçou entre os dirigentes do partido a convicção da necessidade de promover mudanças profundas no PFL. Apesar de a eleição não ter sido desastrosa para o PFL, representou um passo adicional na direção do encolhimento do partido, conforme mostra a Tabela II.2.

Nessa época, ao mesmo tempo em que levava adiante o projeto de refundação do partido, o PFL alimentava a hipótese de lançar candidato próprio na eleição presidencial de 2006. César Maia, reeleito prefeito do Rio de Janeiro em 2004 - o único prefeito de capital eleito pelo PFL naquele ano -, era o novo presidenciável do partido. Conforme declaração de Jorge Bornhausen em 21 de janeiro de 2005, "o partido está lançando a pré-campanha à presidência da República do prefeito do Rio, César Maia. Temos história e temos bandeira. Queremos um país com mais empregos e menos impostos."32 Até o final de 2005, Maia manteve aberta a possibilidade de se apresentar como candidato a presidente. Dizia que somente abriria mão dessa pretensão caso o candidato do PSDB fosse José Serra, porque este, na sua avaliação, seria o único tucano capaz de derrotar Lula. Nas pesquisas, o melhor número obtido por César Maia foi $9 \%$ em junho de 2005, segundo o instituto Ibope. Apareceu pela última vez nas pesquisas em novembro de 2005, quando, de acordo com o instituto Sensus, possuía $6,4 \%$ das intenções de voto. ${ }^{33}$

No final de 2005, Maia passou a afirmar que somente entraria na disputa presidencial caso aparecesse com mais de $15 \%$ nas pesquisas até março do ano seguinte. Muito abaixo do piso que se auto impôs, desistiu da candidatura presidencial. Foi a última vez que um nome do PFL foi cogitado com alguma consistência para a Presidência da República.

O "mensalão", a mais grave crise política dos oitos anos do governo Lula, animou a oposição. O desgaste da imagem do governo provocado pelo mensalão - a avaliação positiva do governo chegou a seu nível mais baixo em dezembro de 2005: 28\%, segundo o Datafolha acendeu as esperanças oposicionistas de derrotar o presidente Lula nas urnas. Enquanto a hipótese de César Maia sair candidato perdia fôlego, Geraldo Alckmin, governador de São Paulo, e José Serra, prefeito de São Paulo, disputavam o posto de candidato a presidente pelo PSDB. O impasse tucano somente foi resolvido em 14 de março de 2006, quando Serra, mais bem posicionado nas pesquisas, ${ }^{34}$ desistiu e Alckmin assumiu a candidatura oposicionista.

\footnotetext{
${ }^{32}$ Folhapress, 21/01/2005.

${ }^{33}$ Informações obtidas no blog do jornalista Fernando Rodrigues (http://noticias.uol.com.br/politica/pesquisas).

${ }^{34}$ Segundo o Datafolha, Serra tinha 31\% das intenções de voto em 21 de fevereiro de 2006, contra 39\% de Lula. No cenário com Alckmin, Lula aparecia com $43 \%$ contra $17 \%$ do governador paulista.
} 
Depois de oito anos, PSDB e PFL novamente se coligaram para disputar a Presidência da República. Mais uma vez, um tucano liderou a chapa e coube ao PFL indicar o vice. A escolha do candidato pefelista a vice não foi tranquila. Dois nomes se apresentaram: os senadores José Jorge (PE) e José Agripino Maia (RN). Com apoio do presidente do partido, Jorge Bornhausen, o senador pernambucano venceu a disputa em um colégio eleitoral composto por 96 pefelistas (deputados federais, senadores, governadores, prefeitos de capital e membros da executiva nacional sem mandato eletivo). José Jorge obteve 51 votos contra 45 de Agripino Maia, que foi apoiado pelo grupo de Antônio Carlos Magalhães.

Desta vez, ao contrário de 1994 e 1998, a aliança entre tucanos e pefelistas não foi bem sucedida. Embalado pelo bom momento da economia e pelo sucesso do programa Bolsa Família, Luiz Inácio Lula da Silva foi reeleito no segundo turno, estendendo por pelo menos mais quatro anos a temporada do PSDB e do PFL na oposição. ${ }^{35}$

\section{Tabela II.3 - Desempenho do PFL na eleição de 2006}

\begin{tabular}{|l|c|c|c|c|}
\hline & Deputados estaduais & Governadores & Deputados Federais & Senadores \\
\hline PFL & $\mathbf{1 1 8 ( 1 1 . 1 \% )}$ & $\mathbf{1}(\mathbf{3}, \mathbf{7} \%)$ & $\mathbf{6 5 ( 1 2 , 7 \% )}$ & $\mathbf{6}(\mathbf{2 2 , 2} \%)$ \\
\hline PT & $126(11,9 \%)$ & $5(18,5 \%)$ & $83(16,2 \%)$ & $2(7,4 \%)$ \\
\hline PMDB & $164(15,5 \%)$ & $7(25,9 \%)$ & $89(17,3 \%)$ & $4(14,8 \%)$ \\
\hline PSDB & $152(14,4 \%)$ & $6(22,2 \%)$ & $66(12,9 \%)$ & $5(18,5 \%)$ \\
\hline
\end{tabular}

* Os valores em parênteses indicam a participação no total de cadeiras em disputa.

Fonte: TSE.

Na eleição de 2006, o PFL enfraqueceu-se um pouco mais. Como mostra a Tabela II.3, elegeu 6 senadores, 65 deputados federais e 118 estaduais, bem menos do que em 2002. 0 PFL obteve resultado expressivo apenas na eleição para o Senado. Foi o partido que mais elegeu senadores em 2006. A pior derrota, ocorreu na eleição para governador - o único governador eleito pelo PFL foi José Roberto Arruda, no Distrito Federal -, especialmente na Bahia, principal base do partido no Nordeste e que sempre foi responsável pela eleição do maior número de deputados federais do partido. O governador Paulo Souto, do PFL, candidato à reeleição, era o favorito e quase venceu a eleição no primeiro turno. Na segunda rodada da disputa, no entanto, foi derrotado pelo petista Jacques Wagner. A perda do governo baiano foi mais passo do processo de enfraquecimento do chamado "carlismo", que começou com a morte de Luis Eduardo Magalhães em 1998. Após o falecimento de Luis Eduardo Magalhães, o carlismo ficou sem alguém para dar prosseguimento à dinastia política da família, e o PFL sem o seu mais acalentado projeto de candidato presidencial. A morte de Antônio Carlos Magalhães em 20 de julho de 2007, nove anos após a de seu filho e alguns meses depois do

\footnotetext{
${ }^{35}$ Para diferentes pontos de vista a respeito da reeleição de Lula ver Balbachevsky e Holzacher (2007), Zucco (2008) e Singer (2009).
} 
desaparecimento do PFL e do surgimento do DEM, representou, provavelmente, o fim do carlismo.

Assim, em 2007, cinco anos após ir para a oposição, o PFL, em seu derradeiro ano, tinha, 782 prefeitos, 4.993 vereadores, 118 deputados estaduais, 56 deputados federais, 17 senadores e 1 governador. ${ }^{36}$ Era ainda um partido grande e importante, mas já era bem menor do que em 1999 quando, bem postado no governo Fernando Henrique Cardoso, disputava ombro a ombro com o PMDB o título de maior partido do Brasil.

Ao mesmo tempo, o PSDB, seu tradicional aliado, também passava por um período de encolhimento, embora não tão agudo quanto o do PFL. No campo governista, Lula, recém reeleito, via suas taxas de popularidade atingirem níveis cada vez mais altos. Além de alavancar a popularidade de Lula, a reeleição quebrou a resistência da ala do PMDB, comandada pelo deputado Michel Temer (SP), que ainda não havia aderido plenamente ao governo. A aliança do PMDB com o governo petista foi reforçada pela ampliação da participação de pemedebistas no ministério. No segundo mandato de Lula, o PMDB ocupou cinco ministérios: Comunicações, Integração Nacional, Previdência, Minas e Energia e Agricultura. Entre os novos ministros, cabe destacar a presença de Geddel Vieira Lima (ministro da Integração Nacional), membro destacado do grupo de Michel Temer e que fez oposição ao governo Lula durante praticamente todo o primeiro mandato.

Esse era o entorno político que cercou a substituição do PFL pelo DEM. As forças oposicionistas estavam fragilizadas e as governistas revitalizadas com a reeleição de Lula.

\section{II.2 - O processo de refundação do PFL}

A ideia de refundar o PFL começou a ser de fato implementada em 2004, embora a intenção de reformular o partido e de mudar o seu nome já tivesse sido discutida pelas lideranças da legenda em 2000, quando chegaram até a aventar a possibilidade de trocar o nome da agremiação para PSL (Partido Social Liberal) ${ }^{37}$. A transição para a oposição deu o empurrão necessário para desencadear o processo.

De certa forma, o encolhimento do PFL facilitou a operação de refundação do partido e de troca do seu nome. A derrota do "carlismo" na Bahia também ajudou. Praticamente desde a sua fundação, o poder no PFL foi dividido entre dois grupos, de convivência nem sempre pacífica. Um chefiado por Antônio Carlos Magalhães e outro comandado por Jorge Bornhausen e Marco Maciel.

\footnotetext{
${ }^{36}$ No caso de prefeito, vereador, deputado estadual e governador são os números dos que foram eleitos. Para deputados federais e senadores, os números se referem ao tamanho das bancadas no ano do surgimento do DEM.

${ }^{37}$ Ver Cantanhêde 2000: 87.
} 
A perda de parlamentares para siglas próximas ao governo Lula e a decadência do carlismo reforçaram o controle de Bornhausen sobre o partido. Ele foi o principal idealizador e condutor do processo de refundação. "Esse momento [da refundação] foi muito refletido, principalmente por mim", nos disse o senador Bornhausen na entrevista. "Eu estava na presidência do partido há dez anos e eu sentia que havia sempre uma campanha negativa em relação ao partido pelo fato de nós sermos os seus principais líderes desde a fundação e de termos participado dos governos militares". (entrevista ao autor)

Apagar, ou ao menos amenizar, os vínculos históricos do PFL com o regime militar foi, portanto, um dos objetivos da refundação. Para tanto, ficou definido que haveria a troca de comando do partido com a ascensão de uma nova geração de políticos. A sucessão geracional ficou marcada pela indicação do deputado Rodrigo Maia, então com 37 anos, para a presidência do DEM.

$\mathrm{Na}$ entrevista que nos concedeu, Antônio Lavareda ressaltou esse ponto relacionado à refundação do partido. Segundo ele, Bornhausen vislumbrou que a mudança de nome deveria ser feita de maneira concomitante à ascensão de novos nomes na burocracia partidária. Seria uma forma de distanciar o PFL de seu passado relacionado ao período militar. "O comando do partido foi às mãos de um punhado de jovens deputados, alguns deles sequer nascidos da época do regime militar e que teriam então uma maior sintonia com esse novo invólucro, digamos assim, da legenda. O presidente Rodrigo Maia, por exemplo, é um garoto filho de um exilado político". (entrevista ao autor)

Segundo Lavareda, o PFL sempre foi visto pela imprensa como "o partido das forças políticas que estiveram no poder durante o período autoritário". Essa versão, "excessivamente simplificada da trajetória política do sistema partidário brasileiro", funcionaria, de acordo com ele, como um "marcador" ideológico do sistema partidário, ao localizar o PFL na ponta direita do espectro ideológico. (entrevista ao autor)

Ainda de acordo com Lavareda, "entre os grandes partidos, foi a primeira mudança geracional deliberada. Nunca tinha ocorrido na história política partidária brasileira. Fazer isso de uma forma pensada, estruturada, selecionar um punhado de jovens, parece simples, mas visto de fora, com cuidado, é uma manobra de engenharia política notável, no meu entendimento. E o mérito disso é do comando do senador Bornhausen. É óbvio que os demais membros do comando do PFL partilharam com ele essa ideia, mas quem a concebeu foi o senador Bornhausen". (entrevista ao autor)

O Partido Popular (PP) espanhol e o Partido Social Democrata (PSD) português serviram de modelo para o processo de refundação idealizado por Bornhausen. Conforme ele nos disse na entrevista, 
"em razão dos contatos que eu tinha com o PP da Espanha e com o PSD de Portugal, eu fui vendo o modelo deles. Ambos se refundaram. E ambos tiveram nascimentos semelhantes ao nosso. O primeiro presidente e fundador do PP, Dom Manoel Fraga, quando este ainda não se chamava PP, foi um ex-ministro da Justiça do Franco ${ }^{38}$, como nós, Marco [Maciel], Guilherme [Palmeira], eu, o [José] Sarney, havíamos sido governo durante o período do regime militar. Então, em determinado momento, o Manoel Fraga fez a refundação do partido. Transformou-o em PP e o entregou à nova geração, liderada pelo José Maria Aznar. Isso fez com que o partido ganhasse nova vida. Já na segunda eleição sob a liderança do Aznar, o PP chegou ao governo da Espanha. ${ }^{39} \mathrm{Em}$ Portugal se deu um processo idêntico. O PSD tinha líderes ligados à ditadura de Salazar ${ }^{40} \mathrm{e}$ também fez sua refundação. Esses modelos serviram de base para a nossa refundação". (entrevista ao autor)

O processo de refundação do PFL teve início oficialmente em 20 de maio de 2005, quando, na cidade do Rio de Janeiro, foi instalado o Congresso de Refundação do partido. No dia anterior, o PFL foi o anfitrião da reunião anual da IDC (Internacional Democrática de Centro), entidade à qual o partido estava filiado. ${ }^{41} \mathrm{~A}$ escolha do Rio de Janeiro não foi casual. Na época, a cidade era governada por César Maia, recém reeleito prefeito da cidade. Naquele momento, César Maia era o político de maior evidência do partido e, como já dissemos, o nome mais lembrado como possível candidato do PFL na eleição presidencial de 2006. César Maia foi também um dos principais defensores do projeto de refundar o partido. Tais fatores certamente foram importantes para que, em março de 2007, praticamente dois anos após o lançamento oficial do processo de refundação, a presidência do partido tenha sido transferida para o deputado Rodrigo Maia, filho de César Maia. A intenção evidente de Jorge Bornhausen ao escolher Rodrigo Maia como seu sucessor foi reforçar a sua aliança com César Maia.

Mas nem todos os setores do PFL regiram com entusiasmo à ideia da refundação. Não houve propriamente oposição, visto que, Antônio Carlos Magalhães, o principal contendor de

\footnotetext{
${ }^{38}$ General Francisco Franco, militar que governou a Espanha entre 1939 e 1973 e líder do franquismo, movimento de direita, de inclinação fascista, que sustentou o seu regime ditatorial durante quase quatro décadas.

${ }^{39}$ Contribuiu para a chegada do PP ao poder na Espanha o desmonte da UCD (Unión de Centro Democrático), partido que, comandado por Adolfo Suárez, assumiu o poder após o fim do regime franquista. O colapso da UCD deixou o campo da centro-direita espanhola livre para ser ocupado pelo PP. Sobre o desaparecimento da UCD, ver Gunther e Hopkin (2002).

${ }^{40}$ António de Oliveira Salazar comandou Portugal de 1933 a 1968. Implantou no país um regime ditatorial de direita de inspiração fascista.

${ }^{41}$ A aproximação com o PP espanhol levou o PFL a se filiar em 2004 à IDC (Internacional Democrática de Centro) - ou Centrist Democrat International, em inglês -, organização que reúne 88 partidos, principalmente europeus e latinoamericanos, de centro direita e ligados à democracia cristã. Além do PP (Espanha), PSD (Portugal) e do DEM, fazem parte da IDC, entre outros, o PAN (Partido Acción Nacional), do México, o PDC (Partido Demócrata Cristiano), do Chile; o PJ (Partido Justicialista), da Argentina; a UMP (Union pour un Mouvement Populaire), da França; e a CDU (Christlich Demokratische Union Deutschlands), da Alemanha. Em entrevista à imprensa, o senador Jorge Bornhausen,, então presidente do partido, justificou dessa maneira a filiação do PFL à IDC: “A IDC e o PFL têm identidade ideológica. Não queremos ser nem de direita nem de esquerda. Somos contra qualquer radicalismo e a favor da economia de mercado com regulação e fiscalização do Estado".
} 
Bornhausen dentro do PFL e única liderança pefelista que foi capaz de se contrapor com algum sucesso ao predomínio da aliança Bornhausen-Maciel, já estava politicamente fragilizado. Mesmo assim, no começo de 2005, Antônio Carlos Magalhães dizia que a discussão a respeito da troca do nome do partido não era importante. Para ele, o importante para o partido não era mudar de estatuto, de sigla ou arrumar um símbolo - cogitava-se à época que o PFL poderia adotar o canário da terra como símbolo - “é arranjar votos e ganhar eleições. Nosso problema não é nada disso. É que o partido sempre foi mais forte no Nordeste do que no Sul e no Sudeste. Mas está perdendo substância, ou seja, votos, em Pernambuco, no Ceará, no Piauí e agora no Maranhão", concluiu o senador baiano. ${ }^{42}$

Contudo, quando Bornhausen resolveu mesmo levar adiante o projeto de refundação do partido, a reação de Antônio Carlos Magalhães foi equivalente à de grande parte dos pefelistas: apoio e adesão, mais reticentes do que entusiasmados. Como nos disse o deputado José Carlos Aleluia em entrevista, a reação de lideranças importantes e mais antigas do partido, que ele não quis identificar, foi de "ceticismo".

Esse tipo de atitude está expressa, por exemplo, na declaração que o senador José Agripino Maia nos deu quando o entrevistamos. Questionado a respeito de sua avaliação sobre o processo de refundação do partido, ele prontamente nos corrigiu, "não é refundação. É atualização programática. Eu acho que refundação é um termo muito pesado. (...) Não é refundação. Isso é atualização de normas e procedimentos e de formulação programática, em função das mudanças que ocorreram no Brasil e no mundo nos últimos anos". (entrevista ao autor)

E mesmo Saulo Queiroz, sempre muito próximo a Jorge Bornhausen, nos revelou na entrevista uma opinião negativa a respeito da refundação do partido. Instado a comparar a fundação e a refundação do PFL, Queiros nos disse que

\footnotetext{
“Não tem nada a ver. A fundação do PFL aconteceu numa conjuntura política importantíssima para o país. Foi determinante no apressamento da transição democrática. (...) Quanto à refundação, tem várias razões. Nenhuma delas é importante. Nenhuma delas eu diria que foi um acerto. Uma delas é que a marca PFL se estigmatizou com um partido de direita que apoiou o regime militar. Essa foi a principal razão [para a refundação e mudança de nome]. Em segundo lugar, houve o objetivo de tentar revitalizar o partido, oferecer uma coisa nova, mudar o comando, colocar gente nova. É aquele negócio, mudar o guarda roupa, tomar um banho de loja. Houve mudança de nome, mas não mudou absolutamente nada na essência". (entrevista ao autor)
}

\footnotetext{
${ }^{42}$ UOL News, 16/01/2005.
} 
A troca de nome e a sucessão geracional no comando do partido também foram vistas com alguma desconfiança pela base do partido, pelos membros dos diretórios estaduais e locais do PFL. Segundo o relatório da $\mathrm{MCl}$, o qual será apresentado com detalhes na próxima seção desta dissertação, a maioria dos candidatos pefelistas a prefeito na eleição de 2004 ouvidos pela empresa repudiou a ideia de mudar o nome do partido. ( $\mathrm{MCl} 2004$ : 156)

Até mesmo Jorge Bornhausen reconheceu que a chamada base do partido resistiu à refundação. "Houve um pouco de desconfiança [da base do partido], uma certa perplexidade. Mas a determinação firme no sentido de fazer venceu esses obstáculos. (...) Acho que [a resistência] era natural. As pessoas estão voltadas para a estabilidade e já estavam acostumadas às lideranças do partido. Colocavam em dúvida a possibilidade de a nova geração tocar o partido". (entrevista ao autor)

O senador José Agripino Maia disse que a refundação do partido, que ele chama de "atualização de programa", não foi discutida com a base do PFL, foi conduzida pelos "ideólogos [do partido], aqueles que formulam o pensamento e que o expõe à sua base". (entrevista ao autor)

De acordo com o deputado José Carlos Aleluia, "as bases resistiram um pouco [ao processo de refundação]. Principalmente no Nordeste, na Bahia. O PFL era um nome bonito. Houve sim certa reação contrária". (entrevista ao autor) Lavareda também nos disse que "os setores mais tradicionais do partido [localizados no Nordeste] até hoje lastimam a perda dessa marca [PFL]". (entrevista ao autor)

\section{II.3 - Imagem e identidade do PFL pré-refundação}

No começo de 2004, o PFL encomendou à empresa $\mathrm{MCl}$ Estratégia, dirigida pelo cientista político Antônio Lavareda, um trabalho de consultoria destinado a avaliar a imagem do partido e recolher informações que auxiliasse a se recolocar no mercado político eleitoral diante de uma novidade importante na história da legenda: a ida para a oposição.

O trabalho foi encerrado em maio de 2004, quando seus resultados, resumidos em um relatório de 172 páginas, foram apresentados em seminário para a cúpula do partido. Para o trabalho, foram realizadas 14 entrevistas com lideranças do PFL, pesquisas quantitativa, face a face, com 2.000 pessoas, e qualitativa: 12 focus groups nas cidades de São Paulo, Belo Horizonte, Uberlândia, Porto Alegre e Recife. Os focus groups foram compostos por homens e mulheres das classes A/B e C/D, com idades entre 18 e 24 anos e 25 a 50 anos, eleitores de diversos partidos ou que não tinham preferência partidária. Foram excluídos os eleitores de perfil classificado pela $\mathrm{MCl}$ como "hard PT", isto é, militantes e eleitores petistas convictos. Além disso, também foram realizadas entrevistas em profundidade com 10 pessoas 
classificadas como "formadores de opinião", grupo composto por jornalistas e articulistas de TV, rádio e jornal, bem como sociólogos e cientistas políticos. ( $\mathrm{MCl} 2004: 6$ )

Na pesquisa quantitativa, o PFL apareceu como o terceiro partido na preferência dos eleitores, praticamente empatado com o PSDB, e atrás do PT e PMDB, como mostra a tabela abaixo.

Tabela II .4: Preferência partidária

\begin{tabular}{|l|c|c|c|}
\hline & $\begin{array}{c}\text { Preferência } \\
\text { (Espontânea) }\end{array}$ & $\begin{array}{c}\text { Preferência } \\
\text { (Estimulada) }\end{array}$ & Rejeição $^{43}$ \\
\hline PT & 15 & 21 & 14 \\
\hline PMDB & 5 & 16 & 11 \\
\hline PFL & 3 & 7 & 10 \\
\hline PSDB & 2 & 6 & 9 \\
\hline PDT & 1 & 4 & 4 \\
\hline
\end{tabular}

Fonte: $\mathrm{MCl}$ (2004)

Na segmentação da preferência pelo PFL, houve homogeneidade nos cortes por sexo, idade e grau de instrução. Mas foram encontradas diferenças significativas em função da região, porte e condição do município. No Nordeste, a preferência (estimulada) pelo PFL estava no mesmo patamar do que a do PT e PMDB: $15 \%$, contra $16 \%$ dos dois últimos. No Norte, a preferência pelo PFL estava um pouco acima da média nacional. Nas demais regiões, em contrapartida, a preferência pelo PFL despencava para 4\% (Sudeste e Centro-Oeste) e para $3 \%$ (Sul).

Com relação ao porte, o PFL era mais bem avaliado nos pequenos municípios (até 20 mil habitantes), onde era apontado como o partido preferido por $11 \%$ dos entrevistados, contra $12 \%$ do PT e $16 \%$ do PMDB. Quanto maior o município, pior era o desempenho pefelista. Nas cidades de 20 a 100 mil habitantes, a preferência pelo PFL caia para $8 \%$ e se reduzia a $4 \%$ nas cidades com mais de 100 mil habitantes. O PFL também era mais forte no interior, onde detinha a preferência de $9 \%$ do eleitorado. Nas capitais, chegava a $5 \%$ e atingia apenas $2 \%$ na periferia das grandes cidades.

\footnotetext{
${ }^{43}$ Para a defesa da importância do conceito de rejeição na análise da identificação partidária no Brasil, ver Carreirão (2007 e 2008). Para uma discussão abrangente da identidade partidária no Brasil pós-redemocratização e de sua relação com a decisão de voto ver Kinzo e Carreirão (2004) e Kinzo (2005).
} 
Entre os eleitores que disseram "gostar" do PFL (24\%, contra $44 \%$ do PT, $35 \%$ do PMDB e $30 \%$ do PSDB), o principal motivo citado para amparar tal atitude em relação à legenda foi a imagem de "preparo e a competência administrativa", item citado por 18\%. Bem atrás, em segundo lugar, aparece o item "políticos e lideranças" do partido, com 8\%, seguido por "preocupação social", com 6\%. Outros motivos foram citados por $26 \%$ dos entrevistados. Mas a maioria (42\%) não soube dizer porque gostava do PFL.

Para os que disseram "não gostar" do PFL (42\%, contra $36 \%$ do PT, e $37 \%$ do PMDB e PSDB), a principal razão alegada foi a questão "ética" (29\%), seguida por "preparo e competência administrativa" (17\%) e "preocupação social" (9\%). Outras razões somaram 21\% e $24 \%$ não souberam responder. É interessante salientar que a ética foi também apontada como a principal motivação para os eleitores não gostarem do PT (44\%), PSDB (34\%) e PMDB $(37 \%)$.

Nos focus groups, a $\mathrm{MCl}$ detectou amplo desconhecimento a respeito do PFL, especialmente entre os jovens. Para ilustrar esse ponto foram destacadas as seguintes frases no relatório final do trabalho: “o PFL é um partido que não conheço. Aqui no Sul a gente não conhece..." (Porto Alegre, homem, adulto, classe C/D); "ele [o partido] deveria divulgar mais aqui. Eu nem sei quem faz parte dele" (Belo Horizonte, mulher, adulto, classe A/B); "quem é o presidente do partido? É Brizola, é?" (Uberlândia, homem, adulto, classe C/D); e "Collor era do PFL, não era?" (Recife, homem, jovem, classe C/D).

O aspecto mais lembrado a respeito do PFL foi a figura de Antônio Carlos Magalhães cuja imagem, preponderantemente negativa, acabava, segundo a avaliação da $\mathrm{MCl}$, preenchendo a falta de informações a respeito do partido. Sobre o ex-senador baiano foram destacadas as seguintes frases: "elitista, coronel voltado para seus interesses, autoritário e sem escrúpulos" (São Paulo, homem, adulto, classe A/B); "é Antônio Carlos Magalhães (Toninho Malvadeza) e nada mais. É dono, é coronel, tudo gira em torno dele" (Belo Horizonte, homem, adulto, classe C/D); “o que ele não é, é nada popular. Ele (Antônio Carlos Magalhães) simboliza tudo o que não deveria ser eleito" (Recife, homem, adulto, classe C/D); "a chaga de nossa política é o Nordeste. Onde é que tem ACM e Cia? Lá ainda tem muitos coronéis" (Porto Alegre, homem, adulto, classe A/B); “ACM é o tipo viciado em política; política para ele é cachaça. Faz tudo para manter o poder, passa por cima de qualquer coisa e qualquer um" (Belo Horizonte, homem, adulto. Classe A/B); "pra mim, PFL lembra Antônio Carlos Magalhães: ultrapassado, radical, coronel; gira em torno dos seus próprios interesses e não quer nada com nada" (São Paulo, mulher, adulto, classe C/D). (MCl 2004, 71) ${ }^{44}$

\footnotetext{
${ }^{44}$ Na entrevista que nos concedeu, Gustavo Krause lembrou da frase da ex-primeira dama Ruth Cardoso, dita em julho de 1994 em entrevista ao Jornal do Brasil. Para defender a aliança do então candidato Fernando Henrique Cardoso com
} 
$\mathrm{Na}$ pesquisa qualitativa, as associações mais frequentes feitas diretamente ao PFL foram as seguintes: "partido do Nordeste, que manipula as camadas mais pobres e menos instruídas (este comentário não foi comum no Nordeste); estagnação; mesmice; conservadorismo; distanciamento do povo; falta de empenho na defesa dos interesses populares; remissão à ditadura; coronelismo; corrupção; e partido de direita". (I bidem: 72).

Já nas entrevistas com os "formadores de opinião", surgiram como pontos negativos do PFL a avaliação de que o partido "é de direita" e "conservador", 45 embora tenha "vergonha" de se assumir com tal, e que sempre se alinhou ao governo. Além disso, foi apontado como “representante das oligarquias regionais periféricas do Norte e do Nordeste e parte do CentroOeste". Outro comentário recorrente foi que o PFL era um partido dividido entre duas alas. Uma, considerada mais "moderna", liderada por Jorge Bornhausen, estaria tentando manter o partido na oposição, após a vitória petista em 2002. A outra, comandada por Antônio Carlos Magalhães, mais "atrasada", que carrega um passivo no campo ético e tem um estilo "autoritário de fazer política", permaneceria "governista". Assim, segundo esses entrevistados, o PFL estaria vivendo uma crise de identidade, decorrente da disputa entre as duas alas e da falta de coerência e fidelidade de seus políticos. Outras marcas negativas do partido apontadas pelos "formadores de opinião" foram a "falta de expressividade nos maiores centros do país" e a subordinação ao PSDB. Um ponto positivo mencionado pelos formadores de opinião a respeito do PFL foi o fato de partido ter "ideologia". O PFL seria um partido com programa, ideias e "posições definidas sobre importantes temáticas da vida do país". (Ibidem: 78)

A pesquisa quantitativa mostrou ainda que Antônio Carlos Magalhães era o político mais conhecido do PFL. O político baiano foi citado espontaneamente por $8 \%$ dos entrevistados como uma liderança pefelista. Jorge Bornhausen (3\%), Roseana Sarney (2\%) e Marco Maciel (2\%) também foram citados. Com relação à imagem dos políticos pefelistas, o mais bem avaliado foi Marco Maciel, citado favoravelmente por $27 \%$ dos entrevistados. Mesmo assim, o saldo da diferença de opiniões favoráveis e desfavoráveis a respeito de Marco Maciel era expressivamente negativo. Antônio Carlos Magalhães apareceu mais uma vez como o político de pior imagem do PFL. $67 \%$ disseram ter opinião "desfavorável" a ele. A Tabela 11.5

o PFL, ela disse que "O PFL tem Antonio Carlos (Magalhães), mas tem Gustavo Krause e Reinhold Stephanes". Implícita na fase estava a ideia de que o primeiro PFL seria do "mau" e o segundo do "bem". Krause nos disse que essa frase lhe causou muito problema dentro do PFL.

${ }^{45}$ Pesquisa de Veiga (2007) sustenta essa informação. Ela analisou a correlação entre a identificação com um determinado partido e as características do eleitor (idade, renda, auto-identificação ideológica, escolaridade, região e avaliação dos governos Lula e Fernando Henrique Cardoso) para os anos de 2002 e 2006. Suas conclusões a respeito do o PFL foram as seguintes: "para o PFL (agora Democratas), os dados mostram que as alterações na idade, na renda familiar, na ideologia do eleitor ou na avaliação da imagem do partido (esquerda/direita) repercutiram de maneira linear na avaliação da legenda em 2002. No entanto, a relação das variáveis com a avaliação da legenda mostrou-se muito fraca, exceto para a ideologia do eleitor. Em 2006, apenas a ideologia do eleitor esteve correlacionada com a avaliação do PFL" (Veiga 2007: 359). Ela afirma ainda que "atualmente, o PFL é a legenda com a qual os eleitores que se reconhecem como de direita no espectro ideológico se identificam” (Idem, Ibidem). 
apresenta a "favorabilidade" dos políticos pefelistas. A título de comparação são apresentados também os dados a respeito de Lula, José Serra, José Sarney e Fernando Henrique Cardoso. É interessante destacar que, à exceção de Antônio Carlos Magalhães, o percentual dos que não souberam avaliar os políticos pefelistas foi sempre superior a $30 \%$.

Tabela II.5: Avaliação dos políticos

\begin{tabular}{|l|c|c|c|c|}
\hline & Favorável & Desfavorável & NR* & Saldo \\
\hline Lula & 66 & 30 & 4 & +36 \\
\hline José Serra & 47 & 43 & 9 & +4 \\
\hline J osé Sarney & 42 & 49 & 9 & -7 \\
\hline Fernando Henrique Cardoso & 43 & 50 & 8 & -7 \\
\hline Marco Maciel & 27 & 41 & 33 & -14 \\
\hline César Maia & 19 & 46 & 35 & -27 \\
\hline José Agripino Maia & 8 & 36 & 56 & -28 \\
\hline Roseana Sarney & 27 & 58 & 15 & -31 \\
\hline J osé Carlos Aleluia & 5 & 37 & 59 & -32 \\
\hline Jorge Bornhausen & 10 & 44 & 46 & -34 \\
\hline Antônio Carlos Magalhães & 19 & 67 & 15 & -48 \\
\hline
\end{tabular}

* Não respondeu.

Fonte: $\mathrm{MCl}(2004: 84)$

Na pesquisa quantitativa também foram avaliados os atributos de imagem referentes aos quatros principais partidos do país naquele momento: PT, PMDB, PSDB e PFL. De forma coerente com a avaliação geral feita sobre o partido, o PFL fica em quarto lugar na maioria dos atributos, em muitos deles embolado com o PSDB. A liderança inconteste é do PT que, em todos os quesitos aparece bem à frente das demais legendas. 
Tabela II.6 - Atributos dos partidos

\begin{tabular}{|c|c|c|c|c|}
\hline & PFL & PT & PSDB & PMDB \\
\hline \multicolumn{5}{|c|}{ ÉTICA/SERIEDADE } \\
\hline Ético e o que mais luta contra a corrupção & 8 & 36 & 9 & 14 \\
\hline Mais sério & 7 & 30 & 9 & 16 \\
\hline Age mais de acordo com o que fala & 10 & 33 & 11 & 16 \\
\hline \multicolumn{5}{|c|}{ POPULAR/SOCIAL } \\
\hline É mais próximo do povo & 6 & 52 & 5 & 13 \\
\hline Mais defende os direitos de cidadania & 7 & 41 & 8 & 13 \\
\hline Mais trabalha pelo social & 8 & 39 & 11 & 14 \\
\hline \multicolumn{5}{|c|}{ COMPETÊNCIA/PREPARO } \\
\hline Tem as melhores ideias & 7 & 38 & 11 & 16 \\
\hline O mais competente & 8 & 29 & 10 & 16 \\
\hline Tem mais capacidade de negociação e de diálogo & 7 & 32 & 12 & 19 \\
\hline \multicolumn{5}{|c|}{ ESTRUTURA/FORÇA } \\
\hline Forte para influir nas decisões do país & 8 & 32 & 13 & 24 \\
\hline O maior & 8 & 25 & 9 & 33 \\
\hline Tem uma história importante & 6 & 32 & 7 & 29 \\
\hline \multicolumn{5}{|c|}{ MODERNIDADE/MUDANÇA } \\
\hline Mais defende as mudanças & 8 & 41 & 9 & 13 \\
\hline
\end{tabular}

Fonte: $\mathrm{MCl}(2004: 94)$.

$\mathrm{Na}$ percepção dos entrevistados, PFL e PSDB eram os partidos que mais faziam oposição ao governo Lula. O primeiro foi apontado como mais oposicionista por $30 \%$ das pessoas pesquisadas, enquanto os tucanos apareciam com $29 \%$. No segmento simpático ao PFL, esse percentual sobe para $36 \%$, e o PSDB fica com $30 \%$. Ainda em relação ao oposicionismo do PFL, 23\% disseram que o partido fazia "oposição radical" ao governo; $25 \%$ qualificaram a postura pefelista como "oposição responsável"; 16\% afirmaram que o PFL apoiava e estava "ajudando o governo". Nas respostas espontâneas, 12\% disseram que o partido estava "em cima do muro".

Um resultado interessante apareceu quando se perguntou aos entrevistados que tipo de oposição o PFL deveria fazer. Somente 6\% optaram pela "oposição radical". Outros 39\% escolheram "oposição responsável". Mas a maioria (42\%) disse que o PFL deveria apoiar e "ajudar o governo Lula a administrar o país".

Tendo como base esses resultados e cumprindo o objetivo do trabalho, qual seja, elaborar "indicações para o reposicionamento estratégico da imagem do partido" (Ibidem: 5), a $\mathrm{MCl}$ propôs ao partido um conjunto de ações visando a "reelaboração da 'marca PFL'" mediante um "processo de atualização do ideário existente, que deve ser orientado para o mercado eleitoral". (Ibidem: 105) Na própria pesquisa, a $\mathrm{MCl}$ identificou as características que o eleitor brasileiro mais apreciaria em um partido político. O partido ideal para o eleitor médio brasileiro, segundo a avaliação da $\mathrm{MCl}$, deve ser: 
1) Democrático, característica que seria muito importante e estaria ligada mais ao modo de o partido administrar a sua conduta no governo ou no parlamento e não à sua estrutura organizacional. Nesse sentido, os eleitores demandam que o partido seja "pluralista, popular, represente os interesses de todos os segmentos sociais (sobretudo os de baixa renda); 'próximo' do povo (com quem deve) estabelecer canais de comunicação não apenas em época de eleição; considere a opinião de todos, mas decide pela maioria; (tenha) capacidade de transigir, negociar (disposto a ceder); transparente; defenda a igualdade de direitos e oportunidades" (Ibidem: 89)

2) Popular (voltado ao social): “ligado ao 'povão'; formado ou representante da 'massa' e não da elite e que (tenha) base popular, apoio e apelo popular; (...) prioridade ao 'social', como tradução simplificada das necessidades básicas da população". (Ibidem: 90) Sobre esse item, o relatório da $\mathrm{MCl}$ diz que "no estrato $C / D$, há alguma sobreposição com o conceito "democrático" no que concerne à participação popular". (I dem)

3) Ético: que cumpre seus compromissos, é formado por políticos sérios e luta contra a corrupção.

4) Moderno: "inovação, ideias novas, atualização das ideias; proposta de soluções concretas para os problemas (classe C/D); clareza e coerência das diretrizes do partido (classe $A / B)$; mudança, adequação às mudanças". (I bidem: 92)

Para tentar enquadrar o PFL ao modelo captado pelas pesquisas e pelas entrevistas, a $\mathrm{MCl}$ considerou, em primeiro lugar, que, tendo em vista as características da base e das lideranças do partido, seria um equívoco procurar dar ao PFL o caráter de "popular". Segundo a $\mathrm{MCl}$, a característica que poderia ser mais bem trabalhada em relação ao PFL seria a democracia. "Conforme indicam alguns itens do estudo (...) o partido pode reforçar o conceito de 'democrático', que, de alguma forma, se aproxima da conotação, conforme já mencionado, de 'popular', 'próximo às pessoas' e 'plural'" (Ibidem: 106). Declarações dos "formadores de opinião" a respeito da importância do PFL para a transição democrática do país foram também utilizadas pelo $\mathrm{MCl}$ para sustentar a ideia de que o partido deveria reforçar a sua ligação com o atributo "democrático". Outra ação recomendada pela $\mathrm{MCl}$ foi a de que o partido investisse na ideia de "mudança" e transmitisse à sociedade que o PFL seria um partido em transformação, o que poderia ser um "fator relevante para ajudar a corrigir sua face conservadora" e de posicionar o partido no “'centro' do espectro político”. (Ibidem: 107)

Como corolário do trabalho, a $\mathrm{MCl}$ sugeriu um conceito para o $\mathrm{PFL}$, o qual serviria de guia para a atuação do partido, para a elaboração de suas propostas de políticas públicas e também para a emissão de mensagens direcionadas à sociedade por parte dos políticos da legenda. Segundo o conceito proposto pela $\mathrm{MCl}$, 


\begin{abstract}
“o PFL é um partido comprometido com as mudanças democráticas, dentro dos marcos legais. Ele se posiciona ao centro do espaço político, distante tanto do imobilismo conservador quanto do mudancismo demagógico, populista e autoritário. O Partido é focado na valorização da cidadania e é formado por um quadro político e técnico competente e qualificado para oferecer ao País soluções modernas, capazes de criar as oportunidades e de promover a mudança social e o desenvolvimento econômico que permitirão ao Brasil crescer, gerar empregos e garantir bem-estar e felicidade aos brasileiros, invertendo o quadro atual de extremas desigualdades, reveladas no montante de $33 \%$ da população vivendo abaixo da linha de pobreza. A atuação do PFL, tanto na oposição quanto no governo, é pautada pela conduta ética e segue os preceitos da economia de mercado com forte responsabilidade social." (I bidem: 110, grifo dos autores)
\end{abstract}

A $\mathrm{MCl}$ sugeriu ainda duas mensagens-modelo que serviriam de guia à comunicação do PFL com os eleitores. A primeira mensagem seria direcionada aos formadores de opinião e aos eleitores de maior renda: “agente importante para a consolidação da democracia brasileira, o PFL atua de maneira ética e programática, com valores claramente estabelecidos e de acordo com os preceitos da economia de mercado, com responsabilidade social. O PFL tem experiência e competência para apresentar uma alternativa moderna para a mudança social e o desenvolvimento econômico do Brasil." (I bidem: 111, grifo dos autores)

Para a opinião pública em geral, a mensagem indicada foi a seguinte: "o PFL é formado por gente séria e competente e tem soluções modernas para combater o desemprego e melhorar os serviços de saúde, educação e segurança. O PFL sabe que os problemas do nosso país só serão resolvidos com a criação de oportunidades para todos os brasileiros. Ouvir a população e respeitar os compromissos assumidos é o caminho para o Brasil mudar de verdade." (Idem, grifo dos autores)

A partir desses conceito e mensagens-modelo, a $\mathrm{MCl}$ elaborou para o PFL uma relação de propostas que comporiam uma "plataforma do século XXI" e cujo mote era "cidadania, democracia e modernidade, com ética e competência". As propostas foram agrupadas em 25 áreas, de "política econômica" a "relações internacionais", passando por "segurança", "saúde", "ecologia", "distribuição de renda", "reforma política", "esportes e lazer" etc. Para os objetivos desta dissertação, não vale a pena reproduzir ou analisar tais propostas, até porque a maioria delas é genérica e, com algumas adaptações, poderia fazer parte do cardápio de qualquer partido, como, por exemplo, esta voltada ao problema da segurança pública: "profissionalizar e aparelhar as polícias federais e estaduais, com a valorização dos seus integrantes, aquisição de equipamentos e armamentos modernos, instituição de sistemas de avaliação de desempenho, incentivo à produtividade, treinamento técnico e aprimoramento nas relações com a comunidade, sob a égide do respeito aos direitos humanos". (I bidem: 128) Mas é interessante 
registrar que o trabalho da $\mathrm{MCl}$ para o reposicionamento do partido no mercado eleitoral e a reconstrução de sua imagem envolveu também a elaboração de propostas de políticas voltadas a áreas bastante diversas como as citadas acima.

Outra recomendação feita pela $\mathrm{MCl}$ ao $\mathrm{PFL}$ foi a de que a estratégia de comunicação do partido estabelecesse um contraponto ao PT, partido que deveria ser o alvo principal dos pefelistas. Primeiro, porque o PT, além de estar no poder, era a legenda "top of mind", como diz o relatório da $\mathrm{MCl}$. É bom lembrar que, no início de 2004, a aprovação popular ao governo de Luiz Inácio Lula da Silva não era significativa. De acordo com o Datafolha, em março de 2004, 38\% da população qualificava a administração petista como ótima ou boa. Assim, no começo de 2004, apostar no fracasso do governo Lula, pressuposto implícito na recomendação de eleger o PT como principal adversário do PFL, não era uma opção despropositada.

A segunda razão para o PFL eleger o PT como adversário preferencial estava diretamente relacionada à primeira. Ao estabelecer um contraponto com o PT, o PFL, segundo a avaliação da $\mathrm{MCl}$, teria condições de disputar com o PSDB a posição de principal partido oposicionista.

Nesse sentido, a $\mathrm{MCl}$ identificou como um dos pré-requisitos para o reposicionamento do PFL “a necessidade de investir em candidaturas próprias já em 2004, principalmente nas 100 maiores cidades do País (e) observar a necessidade de maior inserção no Sul e no Sudeste" e de se livrar da imagem de que o partido seria um satélite do PSDB. "Alterar essa percepção exige que o partido emita sinais reiterados de autonomia, com iniciativa e registros próprios", recomendou a $\mathrm{MCl}$. (Ibidem: 170) Para tanto, seria importante o partido lançar candidatos próprios a governador no maior número possível de estados e disputar a eleição presidencial de 2006 com um representante próprio proveniente dos quadros pefelistas.

Tais recomendações, escreveu a $\mathrm{MCl}$ em seu relatório, são direcionadas a um partido que pretende ser "desafiante", isto é, "que busca competitivamente disputar a liderança no médio prazo, o que supõe procurar inserção, com uma imagem nacional coesa, na opinião pública dos grandes centros urbanos" (Ibidem:172). Essa, contudo, reconhece a $\mathrm{MCl}$, não é a única opção para o PFL. Para a MCl,

\footnotetext{
“um partido não precisa, necessariamente, ser protagonista. Pode ser um ator coadjuvante importante. $\mathrm{E}$, do ponto de vista organizacional, extrair vantagens de outros perfis, como se verifica com o PMDB que, a exemplo dos partidos pré64, adota no dia-a-dia um modelo confederativo e reunifica no Congresso barganhando em bloco com o Executivo, sempre como parceiro privilegiado. Estratégias típicas de partidos coadjuvantes (followers) são imitativas e não inovadoras, enfatizam segmentos muito específicos e se contentam com bolsões regionais". (Idem)
} 
Outros pré-requisitos necessários ao reposicionamento do partido e que foram selecionados pela $\mathrm{MCl}$ foram: 1) a superação da dicotomia entre o lado considerado moderno e atrasado do PFL, este, representado, segundo as informações colhidas entre os formadores de opinião e nas pesquisas qualitativas, pelo grupo político de Antônio Carlos Magalhães; 2) manter preocupação constante a respeito da questão ética. Desvios éticos cometidos por membros do partidos deveriam ser punidos celeremente ${ }^{46}$; 3 ) implementar mecanismos mais abertos e democráticos (como, por exemplo, a realização de primárias) para a escolha de candidatos do partido a cargos majoritários.

\section{II.4 - A mudança do nome}

A $\mathrm{MCl}$ também testou a ideia da mudança do nome do partido. A pesquisa quantitativa realizada pela empresa mostrou que, à exceção do PT, era muito grande o grau de desconhecimento da população a respeito do significado das siglas dos principais partidos brasileiros. No que diz respeito ao $\mathrm{PFL}, 55 \%$ dos entrevistados disseram que não sabiam ou não responderam. $22 \%$ responderam errado e apenas $23 \%$ souberam dizer que PFL significava "Partido da Frente Liberal". Tais percentuais foram semelhantes aos obtidos pelo PSDB e PMDB e contrastam fortemente com o que ocorria em relação ao PT. $64 \%$ das pessoas ouvidas pelo $\mathrm{MCl}$ disseram corretamente que PT era o "Partido dos Trabalhadores". Assim, a princípio, a troca de nome, do ponto de vista da opinião pública em geral, não acarretaria danos ao partido.

Mas a mudança de nome foi condenada pelos chamados formadores de opinião que a qualificaram como uma "tentativa de fugir do passivo de imagem com a adoção de uma nova denominação. (...) Entre os formadores, a ideia da troca do nome chegou a ser considerada uma atitude 'condenável', 'oportunista' e 'comum aos partidos de direita'” (Ibidem: 155). A possibilidade de o partido mudar de nome também não foi muito bem recebida pelas lideranças partidárias entrevistadas, embora a ideia não tenha sido rechaçada com tanto vigor, como ocorreu entre os formadores de opinião.

Especificamente sobre o termo "liberal", a avaliação da $\mathrm{MCl}$ foi que, entre os formadores de opinião, a imagem de que o PFL era um partido liberal já estaria plenamente consolidada. Assim, o sumiço do "liberal" seria indiferente. Já entre o conjunto das pessoas entrevistadas na pesquisa quantitativa prevalecia o desconhecimento a respeito do significado da palavra, que aparecia comumente associada a "liberalidade" ou à "falta de regras". Portanto, também para o grande público, a ausência do termo "liberal" não provocaria grande impacto, segundo a avaliação da $\mathrm{MCl}$. Diante dessas evidências, o relatório concluiu que

\footnotetext{
${ }^{46}$ Essa informação ajuda a entender o estrago que o caso de corrupção envolvendo o ex-governador do Distrito Federal José Roberto Arruda, e que ficou conhecido como o “mensalão do DEM”, causou à imagem do partido.
} 
"alterar a marca PFL poderia, neste momento, mais prejudicar do que contribuir para o reposicionamento partidário". ${ }^{47}$ (I bidem: 156)

A tese da pouca importância da presença da palavra "liberal" no nome do partido foi incorporada ao discurso de Jorge Bornhausen. Perguntado a respeito da polêmica ${ }^{48}$ provocada pela supressão do termo liberal no novo nome do partido, ele disse que "o importante não é o nome liberal. O importante é a ideia liberal. E a ideia liberal foi mantida no documento que foi feito na refundação". (entrevista ao autor)

Opinião semelhante foi revelada pelo senador José Agripino Maia. Segundo ele, não havia razão para manter o termo liberal pois este obrigava o partido a "ficar na defensiva", dada a carga negativa associada ao liberalismo no Brasil. E, como a adesão do partido aos ideais liberais fosse amplamente reconhecida, manter o "termo liberal não era necessário". (entrevista ao autor)

Conforme nos relatou Antônio Lavareda, a ideia de mudar o nome do partido, embora tivesse sido rejeitada pela pesquisa da $\mathrm{MCl}$, foi retomada logo após a eleição de 2006.

O incômodo dos pefelistas com a denominação "Partido da Frente Liberal" era antigo, como indica declaração de Marco Maciel em entrevista para esta dissertação. Segundo o exsenador pernambucano, "nós [os dissidentes do PDS] éramos a chamada Frente Liberal. Quando precisamos definir o nome do partido, ficou 'Partido da Frente Liberal', uma denominação em si contraditória. Ora, nós somos partido ou somos uma frente?". ${ }^{49}$ (entrevista ao autor)

Segundo explicação de Jorge Bornhausen, quando o partido foi formalizado, ficou acertado que o nome Partido da Frente Liberal seria apenas provisório: “A dissidência se chamava Frente Liberal. E nós tínhamos urgência de formar um partido. Então decidimos: 'vamos colocar Partido da Frente Liberal como nome provisório'. E o primeiro estatuto do partido estabeleceu isso, que o nome seria provisório". (entrevista ao autor)

O cientista político Antônio Lavareda, também comentou a incoerência de se acoplar os termos "partido" e "frente". "Partido da Frente Liberal era uma contradição em termos: partido

\footnotetext{
${ }^{47}$ Cantanhêde (2001: 87), destaca que o termo liberal aplicado aos dissidentes do PDS na época em que fundaram o PFL tinha uma conotação mais política do que econômica. Referia-se à oposição desse grupo aos “radicais” e "conservadores" que apoiavam Paulo Maluf.

${ }^{48}$ A respeito dessa polêmica, ver artigo de Rodrigo Maia publicado no jornal Folha de São Paulo (11/12/2007).

${ }^{49}$ Segundo relato de Cantanhêde (2001: 86), o termo "Frente Liberal” foi cunhado pela jornalista Maria Inês Nassif, então no Jornal do Brasil, com o intuito de identificar com uma denominação sucinta o grupo que a imprensa chamava de “deputados do movimento dissidente do PDS” ou de "dissidência parlamentar governista”. O termo pegou. Passou a ser adotado por toda a imprensa e acabou sendo incorporado ao nome do partido.
} 
da frente? O partido pode estar numa frente, mas o partido não pode ser o partido da frente. Já havia essa contradição desses termos lá atrás". (entrevista ao autor)

Na entrevista, Lavareda relatou que “passada a eleição de 2006, conversávamos eu o presidente do partido [Jorge Bornhausen] e uma ideia que eu já tinha tido antes voltou à baila. A partir daí ele [Bornhausen] pediu um estudo específico sobre isso. Fizemos uma pesquisa qualitativa e vários nomes e alternativas surgiram. Com base nesses resultados, eu apresentei ao partido a sugestão de um nome que, primeiro, não tivesse o nome 'partido' e, segundo, que fosse coerente com os resultados da pesquisa que fizemos para o partido em 2004. Então, o presidente [Bornhausen] pediu que eu fizesse uma apresentação sobre a proposta do novo nome para a executiva do partido. Eu fiz e o novo nome foi aprovado na reunião da executiva". (entrevista a autor)

As denominações testadas nos focus groups foram: PMD (Partido da Mudança Democrática), PML (Partido da Mudança Liberal), PRD (Partido da Renovação Democrática), PRL (Partido da Renovação Liberal), PLD (Partido Liberal Democrático), PDL (Partido Democrático Liberal), PLB (Partido Liberal do Brasil) e PCD (Partido de Centro Democrático). Percebe-se que o nome afinal escolhido - Democratas - não foi avaliado nos grupos. Mas o termo "democrático(a)" estava presente na maioria das opções testadas, o que levou Lavareda a sugeri-lo para os dirigentes do partido. 


\section{I - O declínio na oposição}

"A refundação do PFL foi uma estratégia de sobrevivência na oposição" Antônio Lavareda (entrevista ao autor)

A passagem do PFL para a oposição foi o evento determinante para refundação do partido e para o surgimento do DEM. Como disse Lavareda na epígrafe acima, a refundação foi uma tentativa de preparar o partido para sobreviver na oposição. Para os dirigentes pefelistas estava claro que a transferência para a oposição colocaria a legenda diante de um desafio complicado. Afinal, desde que surgiu, o PFL sempre manteve relações próximas com o poder federal, tendo participado de todos os ministérios formados pelos presidentes que governaram o Brasil desde o final do governo militar até a ascensão de Lula. Sem contar que seus principais dirigentes ocuparam posições políticas e administrativas de destaque nos governos militares. E, considerando que PSD e UDN foram os antecessores da Arena e do PDS, pode-se dizer que a ligação entre o grupo político responsável pela criação do PFL e o poder federal é ainda mais remoto.

Essa longa linhagem governista forjou a concepção de que o PFL "estava no poder há 500 anos", como escreveu o jornalista Otavio Frias Filho em sua coluna semanal no jornal Folha de São Paulo em 199550, quando comentou o projeto "PFL 2000" lançado alguns dias antes pelo comando da legenda para prepará-la para o novo milênio. De maneira jocosa, Frias Filho argumentou que o partido não precisava se preocupar com o futuro, pois este certamente Ihe seria favorável. Frias Filho, contudo, não vislumbrou a possibilidade de que, sete anos depois, a trajetória governista do PFL fosse interrompida em decorrência da chegada do PT ao poder, fato que tornou o futuro do partido muito mais incerto do que previa o jornalista.

Nas entrevistas que realizamos, surgiu com frequência a convicção de que a nova condição oposicionista assumida pelo PFL levaria o partido a perder força nas regiões onde era tradicionalmente mais forte, notadamente no Nordeste. Foi essa avaliação que impulsionou os dirigentes do partido a se empenhar na tarefa de recriar o partido, dar-lhe uma nova imagem e reposicioná-lo no mercado político eleitoral brasileiro de modo a transformá-lo em representante das camadas médias da população dos centros urbanos do Sul e Sudeste, ao invés dos grotões nordestinos.

Segundo Lavareda, a refundação do PFL foi decorrente da constatação feita pelos dirigentes do partido de que o PFL “inevitavelmente declinaria no seu mercado tradicional, nos grotões no Nordeste, nas regiões menos desenvolvidas. (...) Sentiam isso a partir do avanço

\footnotetext{
${ }^{50}$ Otavio Frias Filho, “PFL 2000”, Folha de São Paulo, 08/06/1995.
} 
do Bolsa Família, do PT e dos partidos aliados ao PT nesses segmentos. Então havia de se fazer um trade-off entre essa fonte tradicional de votos do partido, que estava inevitável e progressivamente sendo tomada pelos principais adversários do $\mathrm{PFL}$, havia que compensar esse declínio avançando no eleitorado dos centros urbanos grandes e médios. Para isso foi necessário o reposicionamento do partido, do ponto de vista do ideário e da imagem". (entrevista ao autor)

O deputado José Carlos Aleluia (BA) confirmou a ideia do trade-off citada por Lavareda. “Eu, desde o começo do governo Lula, fiz uma previsão, um prognóstico que acabou se confirmando. O Democratas perderia espaço político no Norte e no Nordeste e ganharia espaço no Centro-Oeste, no Sul e até no Sudeste. Nessas próximas eleições [2010], o partido deve diminuir um pouco no Nordeste, mas deve crescer em São Paulo. Deve ir bem também em Santa Catarina e manter o espaço que tem no Paraná e no Rio Grande do Sul". (entrevista ao autor)

Contudo, a previsão de Aleluia não se cumpriu integralmente. De fato, o encolhimento do partido foi mais acentuado no Nordeste. Mas essa tendência não foi compensada em outras regiões. Ao contrário, conforme mostram as tabelas abaixo, desde 2002, a cada nova eleição, o desempenho do partido nas urnas foi cadente em praticamente todas as regiões. Essa é a face mais visível das dificuldades do PFL após rumar para a oposição.

Tabela III.1 - Deputados federais eleitos pelo PFL-DEM por região ( $\%$ do total de cadeiras)

\begin{tabular}{|c|c|c|c|c|c|c|c|}
\hline & 1986 & 1990 & 1994 & 1998 & 2002 & 2006 & 2010 \\
\hline & \multicolumn{7}{|c|}{ Deputados Estaduais } \\
\hline Norte & 15,9 & 9,2 & 13,5 & 16,2 & 9,2 & 8,1 & 5,9 \\
\hline Nordeste & 38,4 & 27,9 & 26,1 & 20,8 & 17,9 & 14,4 & 7,3 \\
\hline Sudeste & 17,2 & 10,3 & 6,6 & 12,9 & 7,0 & 10,0 & 6,6 \\
\hline Sul & 12,8 & 10,1 & 8,7 & 16,2 & 10,7 & 10,1 & 9,4 \\
\hline Centro Oeste & 20,2 & 12,4 & 13,3 & 9,7 & 8,0 & 10,6 & 6,2 \\
\hline \multirow[t]{2}{*}{ Brasil } & 24,2 & 16,0 & 15,1 & 16,2 & 11,5 & 11,1 & 7,1 \\
\hline & \multicolumn{7}{|c|}{ Deputados Federais } \\
\hline Norte & 28,6 & 12,3 & 12,3 & 26,2 & 16,9 & 13,8 & 9,2 \\
\hline Nordeste & 39,1 & 32,5 & 33,8 & 31,1 & 29,1 & 17,9 & 9,9 \\
\hline Sudeste & 14,8 & 7,1 & 9,5 & 14,5 & 10,1 & 8,9 & 6,1 \\
\hline Sul & 13,0 & 10,4 & 13,0 & 13,0 & 6,5 & 13,0 & 7,8 \\
\hline Centro Oeste & 24,4 & 14,6 & 7,3 & 12,2 & 14,6 & 7,3 & 12,2 \\
\hline Brasil & 24,2 & 16,5 & 17,3 & 20,5 & 16,4 & 12,7 & 8,4 \\
\hline
\end{tabular}

Fonte: Nicolau (2010) e TSE

A Tabela III.1 mostra o percentual de deputados federais e estaduais eleitos pelo partido em relação ao total de cadeiras em disputa desde 1986. Já a Tabela III.2 traz o percentual de prefeitos e vereadores do PFL e do DEM. Nos dois casos, os resultados foram agregados por região. 


\section{Tabela III.2 - Vereadores e prefeitos eleitos pelo PFL-DEM por região}

( $\%$ do total de cadeiras)

\begin{tabular}{|l|c|c|c|c|}
\hline \multirow{2}{*}{ Norte } & $\mathbf{1 9 9 6}$ & $\mathbf{2 0 0 0}$ & $\mathbf{2 0 0 4}$ & $\mathbf{2 0 0 8}$ \\
\cline { 2 - 5 } & \multicolumn{4}{|c|}{ Vereadores } \\
\hline Nordeste & 14,8 & 17,2 & 8,3 & 8,7 \\
\hline Sudeste & 23,0 & 19,7 & 11,2 & 9,2 \\
\hline Sul & 17,6 & 18,0 & 12,2 & 10,5 \\
\hline Centro Oeste & 10,8 & 12,3 & 5,8 & 7,7 \\
\hline Brasil & 13,9 & 15,7 & 7,4 & 9,5 \\
\hline & 17,4 & 17,1 & 9,6 & 9,3 \\
\hline Norte & \multicolumn{4}{|c|}{ Prefeitos } \\
\hline Nordeste & 16,0 & 21,6 & 8,9 & 8,8 \\
\hline Sudeste & 24,0 & 24,8 & 23,2 & 8,6 \\
\hline Sul & 17,0 & 15,5 & 12,5 & 10,9 \\
\hline Centro Oeste & 9,4 & 13,3 & 7,2 & 6,6 \\
\hline Brasil & 15,6 & 14,9 & 8,4 & 8,8 \\
\hline
\end{tabular}

Fonte: Nicolau (2010) e TSE

As tabelas mostram que os melhores momentos do PFL na disputa eleitoral ocorreram quando o partido estava aliado a governos bem avaliados na época em que ocorreram as eleições. Isso aconteceu em 1986, primeira eleição disputada pelo recém fundado PFL, quando estava associado ao governo Sarney o qual, embalado pelo efêmero sucesso do Plano Cruzado, gozava de elevada popularidade naquela ocasião. E voltou a se repetir em 1998, ano da reeleição de Fernando Henrique. Infelizmente não foi possível obter dados sobre a eleição de vereadores e prefeitos antes de 1996. Mas as informações disponíveis indicam que também em âmbito municipal o partido teve melhor desempenho nas urnas quando era o principal aliado do presidente Fernando Henrique Cardoso, ou seja, em 1996 e em 2000.

A fase descendente do partido tem início em 2002. Naquele ano, a popularidade de Fernando Henrique já era baixa. Predominava entre os eleitores o descontentamento em relação ao governo tucano e Lula aparecia como o principal favorito para suceder Fernando Henrique Cardoso. Além disso, o PFL, como relatamos no Capítulo 2, havia rompido formalmente com o governo Fernando Henrique Cardoso.

Assim, nos meses que antecederam a eleição de 2002, o PFL já não participava do grupo que estava no poder e as perspectivas da disputa presidencial não apontavam para a possibilidade de o partido ser o principal aliado do presidente que iria substituir Fernando Henrique Cardoso. De fato, o favoritismo de Lula se confirmou e a chegada do PT ao poder fechou as portas do governo federal para o PFL. O senador Antônio Carlos Magalhães, ainda influente no partido, tentou se aproximar do novo governo, mas a maioria do PFL decidiu que a legenda deveria ficar na oposição. 
Segundo relato do senador Bornhausen para este trabalho, "em nota emitida em outubro de 2002, logo após a eleição, deve ter sido lá por 29 ou 30 de outubro, o PFL se colocou na oposição, o que desgostou alguns. Houve certa resistência. O próprio Antônio Carlos [Magalhães] queria retardar esse posicionamento. Mas foi uma nota firme. Porque, para mim, um princípio clássico da democracia é que quem ganha é governo e quem perde é oposição, a quem cabe fiscalizar o governo com responsabilidade". (entrevista ao autor)

Antônio Lavareda, na entrevista que nos foi concedida, disse que essa não era necessariamente a única opção para o partido. "Haveria sempre a alternativa de participar do governo, como o PMDB fez, e também o PP e outros partidos tão ou mais conservadores que o PFL", argumentou Lavareda. (entrevista ao autor)

No entanto, o PFL não se acercou ao governo Lula e, assentado na oposição, o partido, como mostram as Tabelas III.1 e III.2, continuou a definhar a cada eleição que disputou desde então. Isso ocorreu de maneira quase ininterrupta em quase todas as regiões. As exceções foram pontuais e incapazes de reverter o movimento generalizado de declínio. Na eleição para vereador, o partido cresceu somente no Centro-Oeste e no Sul entre 2004 e 2008. Na primeira região, sua participação no total de vereadores eleitos subiu de $7,4 \%$ para 9,5\%. No Sul, passou de $5,8 \%$ para $7,7 \%$.

Na eleição de deputados federais, o partido mostrou alguma vitalidade também no Sul e no Centro-Oeste. No Sul, o percentual de cadeiras obtido pelo PFL passou de 6,5\% para 13,0\% de 2002 a 2006. No Centro-Oeste, avançou de 7,3\% para 12,2\% de 2006 a 2010. Por fim, o percentual de deputados estaduais do PFL aumentou no Sudeste entre 2002 e 2006, tendo passado de 7,0\% para 10,0\%. Mas foram apenas 5 episódios de crescimento em um universo de 40 observações descritas pelas Tabelas III.1 e III.2.

O recuou do PFL-DEM no Nordeste foi particularmente impressionante. Comparando-se 2010 a 1986, a participação do partido no total de deputados federais eleitos na região caiu 29,2 pontos percentuais. Se a base de comparação é 1998, a queda foi menor (21,2 pontos), mas não se pode dizer que tenha sido inexpressiva. Em termos absolutos, o partido perdeu 44 deputados federais na região desde 1986, e 32 desde 1998. Em 2010, elegeu apenas 15 deputados no Nordeste. No caso dos deputados estaduais, a redução foi de 29,2 pontos (base 1986), ou 106 deputados, e 13,5 pontos (base 1998), o que equivale a 46 deputados.

Na esfera municipal a história foi a mesma. O desempenho do PFL-DEM caiu de maneira mais acentuada no Nordeste. Entre 1986 e 2008, a participação dos vereadores pefelistas no total de eleitos no Nordeste caiu 13,8 pontos, o que equivale a 2.687 vereadores. No caso dos prefeitos, a queda foi de 15,4 pontos (250 prefeitos). 
Nas entrevistas feitas para este trabalho, o retrocesso no Nordeste foi citado como uma das razões que motivou os dirigentes a promover a refundação do partido. Segundo Saulo Queiroz, por exemplo, “o PFL se enfraqueceu por uma razão geográfica objetiva. Nosso grande reduto era o Nordeste, que virou reduto do Lula. O Lula no primeiro mandato ganhou o Nordeste. Nós fomos varridos do mapa político a partir do momento em que na última eleição [2006] não elegemos sequer um governador no Nordeste". (entrevista ao autor)

$O$ fato de o enfraquecimento do PFL ter ocorrido de maneira mais acentuada no Nordeste fortalece o argumento de que a passagem para a oposição foi determinante para o declínio do PFL.

Há evidências que sustentam a ideia de que é elevada a dependência do Nordeste em relação ao governo federal. Em primeiro lugar, o Nordeste é a região mais pobre e subdesenvolvida do país. O PIB per capita do Nordeste era de R\$ 7.488 em 2008, último ano em que este dado está disponível em nível regional, contra R\$10.216 do Norte, R\$18.258 do Sul, R\$ 20.372 do Centro-Oeste e R\$21.183 do Sudeste. ${ }^{51}$ Os estados nordestinos são também os de menor IDH, como mostra tabela apresentada no Apêndice 2 desta dissertação.

Além disso, a participação do valor adicionado pela administração, saúde e educação públicas e seguridade social no total do PIB dos estados do Nordeste é superior ao padrão nacional. No Nordeste, o valor médio desse indicador foi de $24,6 \%$ em 2008 , enquanto no Brasil foi de 15,8. ${ }^{52}$ É também acentuada a importância das transferências da União para as finanças dos estados nordestinos. Segundo dados da Secretaria do Tesouro Nacional referentes a 2009, a participação do total de transferências da União, compulsórias ou voluntárias, na receita dos estados nordestinos foi de 33,5\% em 2009. Perde apenas para estados do Norte, para os quais esse valor foi de $37,2 \%$. No conjunto dos estados, essa relação foi de $16,5 \%$. E, como indica a tabela no Apêndice 3 desta dissertação, entre os 15 estados que mais dependem de recursos federais, 8 foram nordestinos.

Por fim, o Nordeste concentra mais da metade do total de beneficiários do Bolsa Família. Segundo dados do Ministério de Desenvolvimento Social referentes a maio de 2011, há 6,621 milhões de beneficiários do Bolsa Família no Nordeste, contra 3,030 no Sudeste, 1,378 no Norte, 1,038 no Sul e 730 no Centro-Oeste.

São números que corroboram a ideia de que o Nordeste tem perante o poder federal uma relação de dependência, que se refletiria no viés governista de sua classe política. Tal avaliação apareceu em algumas das entrevistas feitas com os dirigentes do PFL.

\footnotetext{
${ }^{51}$ Fonte: IBGE. Valores a preços de 2008.

${ }^{52}$ Ver “Contas Regionais do Brasil: 2004 - 2008”, IBGE.
} 
Segundo José Carlos Aleluia - um deputado baiano, ressalte-se -, "a classe dominante no Nordeste, os políticos da região, procuram o poder. Não estão em busca de ideias. São pragmáticos. Aproximar-se do governo é uma necessidade. Muitos municípios não conseguem sobreviver sem aderir ao poder". (entrevista ao autor)

Gustavo Krause, outro político nordestino entrevistado por nós, fez uma observação semelhante. Na entrevista, Gustavo Krause qualifica o governismo do sistema político brasileiro como "uma doença endêmica e epidêmica". Disse que viu isso ocorrer de modo avassalador na "província", referindo-se a Pernambuco, a partir do momento em que o PT chegou ao poder. No Brasil, segundo ele, ocorre o inverso da conhecida frase anarquista "se hay gobierno, soy contra". Aqui, o mote seria, "se hay gobierno soy a favor". "E o infeliz desse fisiologismo, desse patrimonialismo", nos disse Krause, "é que ele embaralha qualquer noção de nitidez ideológica, programática ou doutrinária. No Brasil, o sujeito dorme liberal e acorda socialista", completou.

\section{III.1 - O enfraquecimento decorrente da migração partidária}

A ideia de que a debilidade do PFL pós 2002 se deve à passagem do partido para a oposição é amparada por números a respeito da migração partidária que afetou a legenda. A saída de dezenas de deputados do partido a partir de 2003 ajudou a acelerar o processo de encolhimento do partido. Cinquenta deputados federais deixaram o PFL-DEM desde 2003. Trinta e nove abandonaram o partido na legislatura 2003-2006 e outros 11 na legislatura 2007-2010. Entre esses não estão incluídos três deputados que entraram e saíram do partido durante a legislatura de 2003 e outros quatro que fizeram o mesmo na legislatura de 2007.

Em 2002, o PFL elegeu 84 deputados federais, 21 a menos do que em 1998. Apesar de ter diminuído, era uma bancada expressiva. Perdia apenas para o PT, que elegeu 91 deputados, e superava a do PMDB (74 deputados) e do PSDB (71 deputados). Como mostram os gráficos abaixo, entre a eleição e a posse, 9 deputados deixaram o PFL. Outros 13 fizeram o mesmo em 2003. No final de 2006, a bancada pefelista estava reduzida a 61 deputados. Ou seja, durante a legislatura que teve início em 2003, o PFL perdeu mais deputados em virtude do troca-troca partidário (39 deputados) do que do resultado eleitoral (21 deputados, comparando-se o resultado da eleição de 1998 com a de 2002). A migração partidária também prejudicou o partido na legislatura seguinte, mas de maneira menos acentuada. 


\section{Número de deputados federais que deixaram o PFL nas Legislaturas de 2003 e 2007 Gráficos}

III.1.a

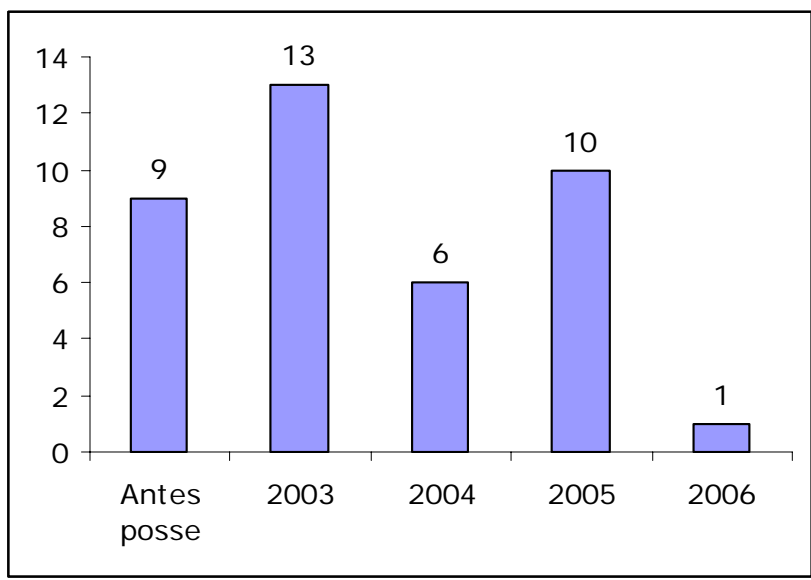

III.1.b

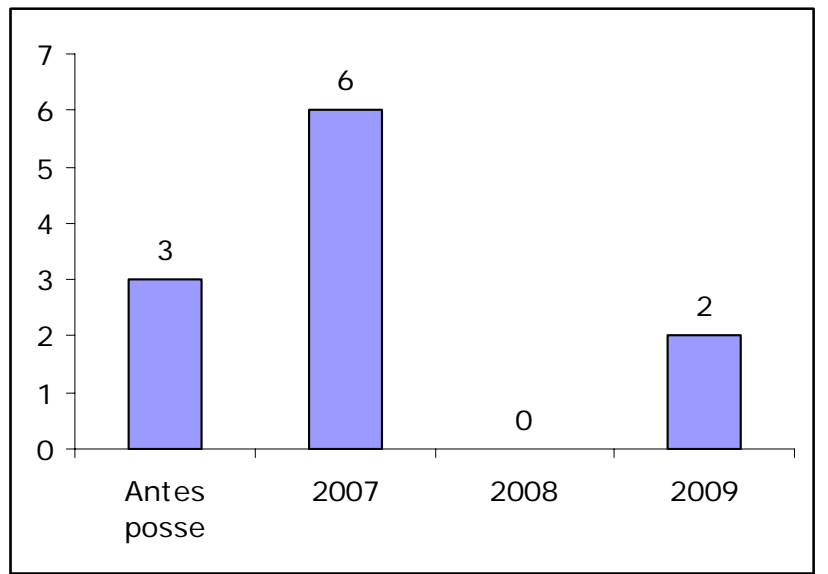

Fonte: Banco de Dados Legislativos do Cebrap.

Naturalmente, a migração partidária no Brasil não é um fenômeno restrito ao PFL. Segundo Freitas, "entre 1995 e 2008 ocorreram 810 trocas de partido, realizadas por 581 parlamentares, ou $24 \%$ dos parlamentares que tomaram posse" (Freitas 2008a: 40). Muitos deles trocaram de partido mais de uma vez em uma mesma legislatura. "Cerca de $48 \%$ dos parlamentares que trocam de legenda, mudam de partido mais de uma vez ao longo do período em que estiveram na Câmara dos Deputados" (I bidem: 42).

Como já mostramos na Capítulo 1, o chamado "troca-troca" partidário costuma ser apresentado na literatura como um indício da precariedade do sistema partidário brasileiro (Melo 2004, Lamounier 2005). Evidenciaria a falta de identidade dos partidos brasileiros que, de modo geral, seriam carentes de feições programáticas e ideológicas próprias, tornando-se pouco distintos entre si. Tais características enfraqueceriam os elos entre os partidos e os políticos a eles filiados. O sistema de eleição proporcional com lista aberta e voto uninominal utilizado no Brasil também contribuiria para debilitar a fidelidade dos políticos aos partidos que o elegeram.

A respeito do transfuguismo partidário, Lamounier (2005) destaca uma declaração do deputado petista Paulo Delgado (MG) e uma entrevista do ex-presidente da Câmara, Severino Cavalcanti (PE). As declarações de Delgado e Severino foram feitas no início de 2005, antes do surgimento do escândalo do mensalão. São, porém, indicativas dos graves problemas que cercavam a construção da base parlamentar do governo Lula.

\footnotetext{
“Ao montar a sua maioria no Congresso, observou Delgado [em entrevista ao jornal Valor Econômico, 12 de março de 2005], o governo Lula aumentou a desarticulação, pois estimulou mais de uma centena de deputados a abandonar
} 
as siglas de oposição e ingressar nas legendas que compunham a base do governo: 'O eleitorado nos deu uma ampla votação majoritária para presidente da República, mas a essa votação não correspondeu uma votação majoritária para a composição do Congresso. Tivemos de fazer composições pós-eleitorais. Isso acabou produzindo uma base instável. Esse fenômeno sempre ocorrerá enquanto não existirem partidos políticos sólidos e organizados verticalmente, com disciplina e organização interna formal, rígida, e também com o voto partidário predominando sobre o individual" (Lamounier 2005: 231-232).

Já Severino, que na época ocupava a presidência da Câmara, fez essas surpreendentes - pela crueza de suas palavras - afirmações em entrevista à Folha de S. Paulo, em 17 de fevereiro de 2005:

“FSP: $[\ldots]$ hoje o PMDB passou o PT em número de deputados.

Severino: Um entra de manhã, sai de tarde, volta de noite. Depois outro e mais outro. Tem que acabar com isso. Isso é uma excrescência, uma indecência. Temos de fazer um projeto aqui na Câmara para acabar com isso. Um recebe dez, outro recebe 15 , outro recebe $20 \ldots$

FSP: $[\ldots] 20$ o quê, reais?

Severino: 20 mil, 30 mil ...Mas eu não tenho provas. Se tiver, vou fazer um inquérito e mandar cassar o mandato. E pegar quem compra e quem vende.

FSP: E se o PMDB ficar maior que o PT na Câmara?

Severino: Acho que não vai ficar. O governo vem aqui, pega um, depois pega outro..." (Idem: 234).

Freitas (2008a), no entanto, como já dissemos no primeiro capítulo desta dissertação, tem uma visão menos negativa a respeito da migração partidária. Ela rejeita a tese de que a migração comprovaria a fragilidade dos partidos brasileiros. Refuta também a ideia de que o fluxo migratório dar-se-ia inequivocamente no sentido da adesão a legendas governistas.

Contudo, a conclusão de Freitas sobre a não existência de um viés governista na migração partidária não se aplica ao PFL. A Tabela III.3 mostra o destino dos deputados federais que deixaram o PFL desde 2003.

$\mathrm{Na}$ Legislatura 2003, 92\% dos deputados que deixaram o PFL se transferiram para legendas aliadas ou próximas ao governo Lula. Nesse percentual não estão incluídos os dois deputados federais do PFL que se transferiram para o PSDB e um deputado que saiu do PFL e permaneceu sem filiação partidária até o final do mandato. Na Legislatura 2007, todos os deputados que deixaram o PFL se afiliaram a partidos aliados ao governo Lula. 
Tabela III.3 - Destino dos deputados federais que deixaram o PFL

\begin{tabular}{|l|c|c|c|}
\hline \multirow{2}{*}{ Partidos de Destino } & \multicolumn{3}{c|}{ Legislaturas } \\
\cline { 2 - 4 } & $\mathbf{2 0 0 3}$ & $\mathbf{2 0 0 7}$ & Total \\
\hline PL/PR & 14 & 5 & 19 \\
\hline PTB & 7 & 1 & 8 \\
\hline PP & 6 & 1 & 7 \\
\hline PPS & 3 & 0 & 3 \\
\hline PMDB & 1 & 2 & 3 \\
\hline PSC & 2 & 0 & 2 \\
\hline PV & 2 & 0 & 2 \\
\hline PSB & 1 & 1 & 2 \\
\hline PSDB & 2 & 0 & 2 \\
\hline Sem partido & 1 & 0 & 1 \\
\hline PRB & 0 & 1 & 1 \\
\hline Total & $\mathbf{3 9}$ & $\mathbf{1 1}$ & $\mathbf{5 0}$ \\
\hline \multicolumn{4}{|c|}{ Fonte: Banco de Dados Legislativos do Cebrap. } \\
\hline
\end{tabular}

Nas entrevistas, a perda de parlamentares para agremiações governistas foi citada como uma oportunidade para a depuração do partido e para a consolidação de seu ideário programático de cunho liberal. O senador José Agripino Maia disse que "talvez esse emagrecimento seja até benéfico. Estão indo os anéis e ficando os dedos. Está ficando a melhor essência. Gente comprometida com os ideais do partido. Aqueles que não são capazes de resistir estão indo embora facilmente. Não é o que temos de melhor. Esses estão ficando". (entrevista ao autor) Já o ex-senador Jorge Bornhausen declarou que a saída de parlamentares do PFL após a eleição de Lula foi um "processo de desidratação que nos livrou de muita gente ruim". (entrevista ao autor)

Provavelmente, o PFL teria perdido mais parlamentares caso decisão do Tribunal Superior Eleitoral (TSE) não tivesse suspendido o livre trânsito de detentores de cargos eletivos entre as legendas. Em 27 de março de 2007, o TSE, em resposta a um questionamento proposto pelo PFL, sacramentou o entendimento de que os mandatos eletivos pertencem aos partidos. Consequentemente, a partir daquela data, políticos que se transferissem para outros partidos passariam a ficar sujeitos à perda de seus mandatos. A decisão do TSE foi confirmada posteriormente pelo Supremo Tribunal Federal (STF), em 04 de outubro de $2010 .^{54}$

\footnotetext{
53 Agradeço a Andréa Freitas por ter me propiciado o acesso a esses dados.

${ }^{54}$ A infidelidade partidária, combatida pelo partido em 2007, foi decisiva para o nascimento do PFL. Em 1994, o PDS entrou com um recurso no Tribunal Superior Eleitoral (TSE) por meio do qual pretendia que políticos pedessistas dissidentes fossem legalmente impedidos de votar no Colégio Eleitoral em desacordo com a orientação da legenda. O TSE, contudo, em 27 de novembro daquele ano, decidiu contrariamente ao pedido do PDS, o que foi fundamental para a vitória de Tancredo Neves no Colégio Eleitoral e para a criação do PFL.
} 
Tabela III .4 - Deputados federais eleitos e que deixaram o PFL, por estado

\begin{tabular}{|c|c|c|c|c|c|c|}
\hline & & 2003 & & & 2007 & \\
\hline & Eleitos & Saíram & $\%$ & Eleitos & Saíram & $\%$ \\
\hline C. OESTE & 6 & 1 & $17 \%$ & 3 & 0 & $0 \%$ \\
\hline Distrito Federal & 1 & 0 & $0 \%$ & 2 & 0 & $0 \%$ \\
\hline Goiás & 3 & 1 & $33 \%$ & 1 & 0 & $0 \%$ \\
\hline M. G. do Sul & 1 & 0 & $0 \%$ & 0 & 0 & - \\
\hline Mato Grosso & 1 & 0 & $0 \%$ & 0 & 0 & - \\
\hline SUDESTE & 18 & 10 & $56 \%$ & 16 & 0 & $0 \%$ \\
\hline Espírito Santo & 0 & 0 & - & 0 & 0 & - \\
\hline Minas Gerais & 7 & 4 & $57 \%$ & 6 & 0 & $0 \%$ \\
\hline Rio de Janeiro & 4 & 2 & $50 \%$ & 5 & 0 & $0 \%$ \\
\hline São Paulo & 7 & 4 & $57 \%$ & 5 & 0 & $0 \%$ \\
\hline SUL & 5 & 1 & $20 \%$ & 10 & 2 & $20 \%$ \\
\hline Paraná & 2 & 0 & $0 \%$ & 5 & 0 & $0 \%$ \\
\hline R. G. do Sul & 1 & 0 & $0 \%$ & 2 & 0 & $0 \%$ \\
\hline Santa Catarina & 2 & 1 & $50 \%$ & 3 & 2 & $67 \%$ \\
\hline NORDESTE & 44 & 20 & $45 \%$ & 27 & 7 & $26 \%$ \\
\hline Alagoas & 2 & 1 & $50 \%$ & 2 & 1 & $50 \%$ \\
\hline Bahia & 19 & 6 & $32 \%$ & 13 & 5 & $38 \%$ \\
\hline Ceará & 2 & 2 & $100 \%$ & 0 & 0 & - \\
\hline Maranhão & 7 & 5 & $71 \%$ & 2 & 0 & $0 \%$ \\
\hline Paraíba & 1 & 1 & $100 \%$ & 1 & 1 & $100 \%$ \\
\hline Pernambuco & 5 & 2 & $40 \%$ & 3 & 0 & $0 \%$ \\
\hline Piauí & 4 & 2 & $50 \%$ & 2 & 0 & $0 \%$ \\
\hline R. G. do Norte & 2 & 1 & $50 \%$ & 1 & 0 & $0 \%$ \\
\hline Sergipe & 2 & 0 & $0 \%$ & 3 & 0 & $0 \%$ \\
\hline NORTE & 11 & 7 & $64 \%$ & 9 & 2 & $22 \%$ \\
\hline Acre & 0 & 0 & - & 0 & 0 & - \\
\hline Amapá & 0 & 0 & - & 1 & 0 & $0 \%$ \\
\hline Amazonas & 3 & 2 & $67 \%$ & 1 & 1 & $100 \%$ \\
\hline Pará & 1 & 0 & $0 \%$ & 2 & 0 & $0 \%$ \\
\hline Rondônia & 1 & 1 & $100 \%$ & 0 & 0 & - \\
\hline Roraima & 3 & 2 & $67 \%$ & 2 & 0 & $0 \%$ \\
\hline Tocantins & 3 & 2 & $67 \%$ & 3 & 1 & $33 \%$ \\
\hline BRASI L & 84 & 39 & $46 \%$ & 65 & 11 & $17 \%$ \\
\hline
\end{tabular}

Fontes: Nicolau (2010) e Banco de Dados Legislativos do Cebrap.

Em valores absolutos, a Bahia concentrou o maior número de deputados federais pefelistas migrantes. Foram seis na legislatura 2003 e outros cinco entre 2007 e 2009. Em segundo lugar, ficou o Maranhão. Em termos regionais, o Nordeste contribuiu com o maior número de dissidentes: 27, sendo 20 na legislatura 2003 e 7 na legislatura de 2007. Sudeste e Norte ficaram em segundo e terceiro lugar, com 10 e 9 deputados, respectivamente. Porém, ponderando o número de deputados migrantes pelo de deputados eleitos em cada estado e região, a Bahia e o Nordeste perdem a liderança. Em alguns estados - Ceará (2003), Paraíba (2003 e 2007) e Rondônia (2003), a taxa de transferência para outros partidos foi de $100 \%$. Isto é, a bancada estadual pefelista reduziu-se a zero. Porém foram estados em que o PFL 
elegeu no máximo 2 deputados. Em termos regionais, a taxa de migração foi maior no Norte e no Sudeste, na legislatura 2003, e no Nordeste, na legislatura 2007.

A queda da Bahia e do Nordeste no "ranking" de estados e regiões de origem dos deputados migrantes quando se considera a taxa de transferência e não os seus números absolutos é um resultado natural. Decorre do fato de terem uma "base" ampla, pois foram responsáveis, respectivamente, pela eleição de $23 \%$ e $52 \%$ do total de deputados federais do PFL em 2002, e por $20 \%$ e $41 \%$ em 2006. Assim, a posição intermediária da Bahia e do Nordeste no que diz respeito à taxa de transferência não reduz a importância dessas regiões no processo de encolhimento do PFL. Afinal 27 deputados nordestinos deixaram o PFL nos oito primeiros anos após o partido ter rumado para a oposição, sendo 11 da Bahia. É quase o triplo dos 10 deputados do Sudeste que saíram do partido no mesmo período.

\section{III.2 - O enfraquecimento nas bases tradicionais}

Outra maneira de vislumbrar os efeitos da transição do PFL para a oposição é analisar o desempenho do partido nas últimas três eleições municipais. ${ }^{55}$ Utilizaremos os dados eleitorais dessas eleições como subsídio básico para mostrar, por meio de uma análise descritiva de dados e também de modelos estatísticos, como o PFL foi perdendo força em seus redutos eleitorais mais tradicionais à medida que se distanciou do poder central. A escolha das eleições municipais para analisar os efeitos da passagem do PFL para a oposição decorre de dois fatores: 1) como o último - e único - candidato pefelista a presidente foi Aureliano Chaves em 1989, não há como utilizar a eleição presidencial como base para a análise do desempenho do eleitoral do PFL; 2) as eleições para a Câmara Federal e para o Senado também não são adequadas para os nossos objetivos, pois não nos permite identificar com precisão a base eleitoral local dos candidatos eleitos pelo partido.

Na primeira dessas eleições, em 2000, o PFL ainda era um partido governista. Nas duas últimas, 2004 e 2008, já havia passado à oposição. Em 2008, se apresentou nas urnas pela primeira vez como DEM, após passar pelo processo de refundação que, conforme vimos, tinha como um de seus objetivos alcançar um eleitorado diverso do que, historicamente, votava no partido.

A fim de avaliar os efeitos que a passagem à oposição acarretou à base eleitoral do PFL, partimos da hipótese de que há municípios com viés governista. O governismo é aqui definido em relação ao poder nacional. Ou seja, são considerados governistas os partidos que participavam da coligação que apoiava o governo federal na época da eleição.

\footnotetext{
${ }^{55}$ Os municípios têm sido crescentemente utilizados como base para análises empíricas a respeito de eleições no Brasil. Ver, como exemplos, Almeida e Carneiro (2008) e Zucco (2010).
} 
Como desdobramento de nossa hipótese inicial, assumimos que os municípios tendentemente governistas possuem as seguintes características: 1) estão localizados principalmente no Nordeste; 2) são pequenos e pouco desenvolvidos; 3) sua economia é dependente do setor público. São características que definem o que se costuma chamar de "grotões", cidades pequenas, pobres, dependentes de recursos públicos e localizadas nas regiões menos desenvolvidas do país. Três autores justificam esse perfil traçado para os municípios teoricamente governistas.

O primeiro deles é Victor Nunes Leal (1978 [1949]), para quem, os municípios com as feições acima apresentadas seriam os mais propensos a fazer parte da engrenagem político econômica analisada por ele e que atrelava os interesses dos mandatários políticos locais ao poder federal, com a intermediação do governo estadual. A situação político institucional, econômica, social e demográfica do país se alterou profundamente em relação à realidade que motivou o clássico estudo de Leal sobre o coronelismo no Brasil. A autonomia do poder local é provavelmente maior nos dias de hoje do que nas primeiras décadas do século passado, período estudado por Leal. E, se os municípios com as características acima definidas ainda expressam a propensão de seguir os ventos políticos que sopram na esfera federal, os mecanismos que conectam o poder local ao nacional são certamente distintos dos descritos por Leal. Mesmo assim, a político-dependência do poder local em relação ao poder federal, fenômeno estudado pelo autor, ainda parece subsistir no Brasil contemporâneo e esta dissertação apresenta evidências nesse sentido.

Já em Schwartzman (1982), essa político-dependência é apresentada como um fenômeno mais forte em certas regiões do país. Seria um desdobramento do débil desenvolvimento econômico dessas regiões e das características históricas das relações entre o mercado e o Estado ali desenvolvidas. Nessas regiões, essencialmente, de Minas Gerais para cima, as relações políticas predominantes seriam do tipo de "cooptação", argumenta Schwartzman, e não de "representação", a qual estaria mais presente apenas em São Paulo.

“O que a análise histórica sugere é que as elites regionais no Centro, Nordeste e, em certa medida, no Sul do país, tendem historicamente a se preocupar menos com a representação de seus interesses no centro político nacional do que com o seu acesso a posições de poder e prestígio em um regime político centralizado. Os esforços eventuais de autonomia local tendem geralmente a ser facilmente ou cooptados pelo centro, ou suprimido pelas elites locais com o apoio do governo central. (...) Um regime político baseado na centralização do poder e cooptação de setores mais ativos tende à excessiva burocratização e à política de distribuição de recursos entre clientelas eleitorais". (Schwartzman 1982: 158) 
Como apontamos no Capítulo 1, a cooptação política é descrita por Schwartzman como um "sistema de participação política débil, dependente, controlado hierarquicamente, de cima para baixo" no qual a "participação política deixa de ser um direito e torna-se um benefício outorgado, em princípio revogável" e que tende a predominar em "contextos em que estruturas governamentais fortes e bem-estabelecidas antecedem historicamente os esforços de mobilização política de grupos sociais". (Ibidem: 37) Assim, nesse sistema, "a administração pública é vista como um bem em si mesmo, e a organização governamental tem as características de um patrimônio a ser explorado e não de uma estrutura funcional a ser acionada para a obtenção de fins heterônimos" (Ibidem: 37-38) e "quanto mais íntima a participação do líder na burocracia governamental, maior sua força política, já que terá mais recursos para manter o controle de suas bases" (Ibidem: 39).

Segundo Schwartzman, em decorrência de sua formação histórica, São Paulo tornou-se uma espécie de território resistente ao patrimonialismo. Por conta disso, em São Paulo, cuja pujança econômica, não se traduziu, até os anos 80 , em força política proporcional na esfera de poder nacional, estariam concentradas forças sociais e políticas que, caso se tornassem hegemônicas no país, poderiam romper com o neopatrimonialismo. ${ }^{56}$

\begin{abstract}
“Parece que alguma forma de política de grupos de interesse (ou política de classe) está na raiz da maioria das versões contemporâneas de democracia política, e uma das conclusões que poderiam ser extraídas dessa análise seria por exemplo, que existiria somente uma forma de levar o Brasil para um sistema mais aberto de participação política: fomentar o papel de São Paulo na política nacional, ao longo de toda a sua estrutura de estratificação sócioeconômica, fazendo com que este sistema regional se expanda até predominar sobre as demais áreas do país, urbanas não-industriais e rurais". (Ibidem: 39)
\end{abstract}

O próprio autor reconhece que esta proposição é simplista. Porém, de acordo com ele, é uma abordagem que abre um horizonte interessante para a análise do modelo político brasileiro. ${ }^{57}$

\footnotetext{
${ }^{56}$ Fernando Henrique Cardoso (1975:72) fez uma avaliação semelhante à de Schwartzman. Ao comentar as perspectivas de evolução do PMDB a partir da vitória obtida pelo partido na eleição de 1974, Cardoso afirma que se o "PMDB quiser marchar no sentido de constituir-se como um grande partido de massas terá que aumentar a participação popular em seus quadros, vincular-se mais às organizações de base (...), ampliar sua capacidade de representar interesses grupais importantes (...) e, especialmente, terá que atualizar constantemente a temática e a perspectiva oposicionista, evitando os riscos óbvios da cooptação e da política de conchavos na cúpula. A efetividade destes quesitos requer e depende de um grau elevado de democracia interna e de um sistema de capilaridade entre o partido e as organizações da sociedade civil. Esta última, apesar das conhecidas e reais limitações à sua vigência numa sociedade como a brasileira, se tem chances de existir (como tem) é a partir de, ou sobretudo em, São Paulo, estado industrializado e urbanizado" (Cardoso 1975:72, grifos nossos).

${ }^{57}$ A chegada de Fernando Henrique Cardoso e de Lula à presidência quebrou esse paradigma apontado por Schwartzman. Com eles e seus respectivos grupos políticos, São Paulo alcançou o centro do poder nacional. Essa novidade oferece uma boa oportunidade a quem se dispuser a atualizar e, de certa forma, testar a análise de
} 
Por fim, Zucco (2010), trabalhando com dados empíricos sobre as eleições presidenciais de 1994 a 2010 chega à conclusão de que os eleitores dos municípios mais pobres e menos desenvolvidos do país parecem ter predisposição maior a votar no candidato governista, fenômeno que ele chama de "incumbency effect".

\begin{abstract}
"Incumbency, as it turns out, seems to have a conspicuous effect on electoral voting patterns. As first noted in Zucco Jr. (2008), all recent incumbent party candidates got a proportionally higher share of votes in poorer places while the reverse applies to the main party in opposition. This does not mean that the incumbent party candidate always wins elections in poorer places, as his average level of support can vary for many different reasons. It does suggest, however, that incumbents have a buit-in advantage in reaching these voters" (Zucco 2010: 5)
\end{abstract}

A conclusão de Zucco corrobora, portanto, a ideia de que municípios mais pobres tendem a apresentar viés governista, neste caso expresso na decisão de voto de seus eleitores na disputa presidencial.

\title{
EVI DÊNCI AS EMPÍ RI CAS
}

A análise descritiva dos dados relativos às eleições municipais de 2000, 2004 e 2008 leva em conta os números apresentados nas Tabelas III.5, III.6 e III.7 abaixo. A Tabela III.5 mostra o desempenho dos oito principais partidos brasileiros que, juntos, respondem por cerca de $90 \%$ dos prefeitos eleitos nas três eleições aqui consideradas. Os partidos foram divididos em governistas e não governistas. ${ }^{58} \mathrm{Na}$ primeira coluna são apresentados os resultados gerais, isto é, considerando-se o total de municípios para os quais foi possível encontrar os dados selecionados. Na segunda coluna, foram destacados apenas os municípios com menos de 20 mil habitantes. Na terceira, os municípios localizados no Nordeste. Na quarta, os municípios de IDH (Índice de Desenvolvimento Humano) ${ }^{59}$ baixo, assim definidos como os que possuíam IDH abaixo da média menos um desvio padrão (IDH menor do que 0,616). Na quinta coluna, estão contemplados os municípios de maior relação entre a contribuição da administração pública para o PIB municipal (APU) e o valor total do próprio PIB do município

\footnotetext{
Schwartzman. A pergunta a ser respondida é: a chegada de São Paulo ao poder foi suficiente para, nos termos propostos por Schwartzman e por Cardoso (1975), fazer com o que modelo de representação finalmente se tornasse hegemônico no país, ou, ao contrário, o modelo de cooptação continua relevante?

${ }^{58}$ Para a distinção entre partidos governistas e não governistas, utilizamos a classificação apresentada na Tabela B.1 da dissertação de Freitas (2008: 120-124). A única diferença é o PTB ao final do governo Fernando Henrique Cardoso, que Freitas classifica como oposição e nós como governista. Decidimos situar o PTB no campo governista em 2000 porque este partido, à exceção dos dois últimos anos, apoiou fortemente o governo Fernando Henrique desde o início. E mesmo no final, a semelhança das votaç̃os de sua bancada no Congresso em relação à posição adotada pelo PSDB continuou elevada (78\%, segundo cálculo de Freitas).

${ }^{59}$ Os valores do IDH são referentes a 2000, último ano em que esta informação está disponível a nível municipal.
} 
(APU/PIB) ${ }^{60}$. Neste caso, foram selecionados os municípios com APU/PIB superior a 0,403 (média mais um desvio padrão calculados a partir da série completa). ${ }^{61}$

Mas qual é a relevância dos municípios pouco populosos, de baixo IDH e elevada relação APU/PIB no conjunto do eleitorado brasileiro? No contexto nacional, notadamente em relação às duas últimas características, de fato não são muito relevantes. A população dos municípios com menos de 20 mil habitantes corresponde a 19,9\% de toda a população nacional. Para os de baixo IDH e elevada APU/PIB, o percentual cai expressivamente para $9,4 \%$ e $7,6 \%$, respectivamente. Portanto, em termos nacionais, pode-se dizer que o controle do poder nesses municípios não é muito importante. A conclusão se altera, no entanto, se restringirmos nossa análise apenas ao Nordeste. Considerando somente as cidades nordestinas, a população dos municípios com menos de 20 mil habitantes corresponde a $25,5 \%$ do total da região. A diferença em relação à esfera nacional é ainda mais acentuada para o IDH e APU/PIB. No Nordeste, a participação sobe para $30,2 \%$ e $19,7 \%$, respectivamente. Ou seja, no Nordeste, os municípios que possuem as características que selecionamos respondem por $20 \%$ a $30 \%$ de todo o eleitorado (assumindo que há plena correspondência entre número de habitantes e de eleitores). Não é uma parcela desprezível, nem para as disputas majoritárias, nem para as proporcionais.

Feita essa consideração, vamos analisar primeiro a situação do PFL ilustrada nas tabelas. Em 2000 e em 2004 nota-se nitidamente que o desempenho do partido é bem melhor nos municípios que caracterizamos como de viés potencialmente governista (menos de 20 mil habitantes, nordestinos, IDH baixo e APU alto) do que no conjunto de todos os municípios. Em 2000, o PFL conseguiu eleger $18,5 \%$ dos prefeitos de todas as cidades do país. Já entre os municípios do menos de 20 mil habitantes, conquistou 19,8\% das prefeituras em disputa. E o desempenho do partido foi ainda melhor no Nordeste, onde conseguiu eleger $24,7 \%$ do total de prefeitos, e nos segmentos IDH baixo e APU elevado, $24,7 \%$ e $24,4 \%$ dos prefeitos eleitos, respectivamente.

Em 2004, o resultado geral do partido declina na comparação com a eleição anterior. O percentual de prefeitos eleitos pelo PFL no total de municípios cai para 14,2\%, percentagem praticamente igual à obtida nos municípios com menos de 20 mil (14,8\%). Contudo, a

\footnotetext{
${ }^{60}$ Para comentários a respeito do valor agregado da administração pública para o PIB municipal, ver páginas 45 a 48 de relatório do IBGE, “Análise dos resultados - Produto Interno Bruto dos Municípios (2004-2008)”, www.ibge.gov.br/home/estatistica/economia/pibmunicipios/2004_2008/comentarios.pdf.

${ }^{61}$ A variável relação APU/PIB para os municípios, até onde sabemos, está sendo utilizada pela primeira vez neste trabalho. Não há, portanto, um parâmetro estabelecido para definir a partir de qual valor pode-se dizer que esta relação é alta. Quanto ao IDH, no Relatório de Desenvolvimento Humano do PNUD de 2010, os países de IDH abaixo de 0,470 foram considerados de "desenvolvimento humano baixo". Contudo, apenas um município brasileiro possui IDH inferior a 0,470. Esse, portanto não é um parâmetro que podemos aplicar ao nosso trabalho. Assim, na falta de parâmetros conhecidos e utilizáveis, escolhemos um critério puramente estatístico para definir o que para nós significa IDH baixo e relação APU/PIB elevada.
} 
discrepância entre esses resultados e a performance no Nordeste, nos municípios de IDH baixo e APU alto se acentuou. Nesses últimos três segmentos, o PFL conquistou 23,1\%, 21,9\% e $20,3 \%$ das prefeituras, respectivamente.

Tabela III .5 - Resultado das eleições municipais, geral e por segmentos

\begin{tabular}{|c|c|c|c|c|c|c|c|c|c|c|}
\hline \multicolumn{11}{|c|}{2000} \\
\hline & \multicolumn{2}{|c|}{$\begin{array}{l}\text { GERAL } \\
\text { (I) }\end{array}$} & \multicolumn{2}{|c|}{$\begin{array}{c}-20 \mathrm{MIL} \\
\text { HABITANTES } \\
(\text { II })\end{array}$} & \multicolumn{2}{|c|}{$\begin{array}{l}\text { NORDESTE } \\
(\text { III) }\end{array}$} & \multicolumn{2}{|c|}{$\begin{array}{l}\text { IDH BAIXO } \\
(\text { IV) }\end{array}$} & \multicolumn{2}{|c|}{$\begin{array}{l}\text { APU/PIB ALTO } \\
\text { (V) }\end{array}$} \\
\hline & $\mathrm{N}=$ & 5491 & $\mathrm{~N}=$ & 4006 & $\mathrm{~N}=$ & 1776 & $\mathrm{~N}=$ & 1132 & $\mathrm{~N}=$ & 1096 \\
\hline PFL & 1018 & $18.5 \%$ & 795 & $19.8 \%$ & 439 & $24.7 \%$ & 280 & $24.7 \%$ & 267 & $24.4 \%$ \\
\hline PSDB & 978 & $17.8 \%$ & 701 & $17.5 \%$ & 288 & $16.2 \%$ & 180 & $15.9 \%$ & 179 & $16.3 \%$ \\
\hline PMDB & 1244 & $22.7 \%$ & 961 & $24.0 \%$ & 353 & $19.9 \%$ & 238 & $21.0 \%$ & 241 & $22.0 \%$ \\
\hline $\mathrm{PP}$ & 601 & $10.9 \%$ & 463 & $11.6 \%$ & 147 & $8.3 \%$ & 108 & $9.5 \%$ & 99 & $9.0 \%$ \\
\hline PTB & 396 & $7.2 \%$ & 280 & $7.0 \%$ & 128 & $7.2 \%$ & 85 & $7.5 \%$ & 79 & $7.2 \%$ \\
\hline GOVERNI STAS & 4237 & $77.2 \%$ & 3200 & $79.9 \%$ & 1355 & $76.3 \%$ & 891 & $78.7 \%$ & 865 & $78.9 \%$ \\
\hline PT & 186 & $3.4 \%$ & 92 & $2.3 \%$ & 21 & $1.2 \%$ & 9 & $0.8 \%$ & 17 & $1.6 \%$ \\
\hline PDT & 280 & $5.1 \%$ & 191 & $4.8 \%$ & 46 & $2.6 \%$ & 35 & $3.1 \%$ & 39 & $3.6 \%$ \\
\hline PL & 233 & $4.2 \%$ & 167 & $4.2 \%$ & 102 & $5.7 \%$ & 63 & $5.6 \%$ & 52 & $4.7 \%$ \\
\hline PSB & 133 & $2.4 \%$ & 75 & $1.9 \%$ & 70 & $3.9 \%$ & 33 & $2.9 \%$ & 45 & $4.1 \%$ \\
\hline $\begin{array}{l}\text { NÃO } \\
\text { GOVERNI STAS }\end{array}$ & 832 & $15.2 \%$ & 525 & $13.1 \%$ & 239 & $13.5 \%$ & 140 & $12.4 \%$ & 153 & $14.0 \%$ \\
\hline TOTAL & 5069 & $92.3 \%$ & 3725 & $93.0 \%$ & 1594 & $89.8 \%$ & 1031 & $91.1 \%$ & 1018 & $92.9 \%$ \\
\hline \multicolumn{11}{|c|}{2004} \\
\hline & \multicolumn{2}{|c|}{ GERAL } & \multicolumn{2}{|c|}{$\begin{array}{c}-20 \mathrm{MIL} \\
\text { HABITANTES }\end{array}$} & \multicolumn{2}{|c|}{ NORDESTE } & \multicolumn{2}{|c|}{ IDH BAIXO } & \multicolumn{2}{|c|}{ APU ALTO } \\
\hline & $\mathrm{N}=$ & 5491 & $\mathrm{~N}=$ & 3934 & $\mathrm{~N}=$ & 1776 & $\mathrm{~N}=$ & 1133 & $\mathrm{~N}=$ & 1095 \\
\hline PT & 407 & $7.4 \%$ & 258 & $6.4 \%$ & 65 & $3.7 \%$ & 49 & $4.3 \%$ & 54 & $4.9 \%$ \\
\hline PDT & 302 & $5.5 \%$ & 217 & $5.4 \%$ & 46 & $2.6 \%$ & 37 & $3.3 \%$ & 41 & $3.7 \%$ \\
\hline PSB & 173 & $3.2 \%$ & 118 & $2.9 \%$ & 106 & $6.0 \%$ & 64 & $5.7 \%$ & 77 & $7.0 \%$ \\
\hline PMDB & 1041 & $19.0 \%$ & 780 & $19.5 \%$ & 353 & $19.9 \%$ & 175 & $15.5 \%$ & 162 & $14.8 \%$ \\
\hline PP & 538 & $9.8 \%$ & 409 & $10.2 \%$ & 122 & $6.9 \%$ & 69 & $6.1 \%$ & 69 & $6.3 \%$ \\
\hline $\mathrm{PL}$ & 376 & $6.8 \%$ & 278 & $6.9 \%$ & 102 & $5.7 \%$ & 100 & $8.8 \%$ & 100 & $9.1 \%$ \\
\hline PTB & 419 & $7.6 \%$ & 303 & $7.6 \%$ & 132 & $7.4 \%$ & 96 & $8.5 \%$ & 91 & $8.3 \%$ \\
\hline GOVERNI STAS & 3256 & $59.3 \%$ & 2363 & $59.0 \%$ & 926 & $52.1 \%$ & 590 & $52.1 \%$ & 594 & $54.2 \%$ \\
\hline PFL & 782 & $14.2 \%$ & 594 & $14.8 \%$ & 411 & $23.1 \%$ & 248 & $21.9 \%$ & 222 & $20.3 \%$ \\
\hline PSDB & 867 & $15.8 \%$ & 602 & $15.0 \%$ & 232 & $13.1 \%$ & 148 & $13.1 \%$ & 154 & $14.1 \%$ \\
\hline $\begin{array}{l}\text { NÃO } \\
\text { GOVERNI STAS }\end{array}$ & 1649 & $30.0 \%$ & 1196 & $29.9 \%$ & 643 & $36.2 \%$ & 396 & $35.0 \%$ & 376 & $34.3 \%$ \\
\hline TOTAL & 4905 & $89.3 \%$ & 3559 & $88.8 \%$ & 1569 & $88.3 \%$ & 986 & $87.1 \%$ & 970 & $88.5 \%$ \\
\hline \multicolumn{11}{|c|}{2008} \\
\hline & \multicolumn{2}{|c|}{ GERAL } & \multicolumn{2}{|c|}{$\begin{array}{c}-20 \mathrm{MIL} \\
\text { HABITANTES }\end{array}$} & \multicolumn{2}{|c|}{ NORDESTE } & \multicolumn{2}{|c|}{ IDH BAIXO } & \multicolumn{2}{|c|}{ APU ALTO } \\
\hline & $\mathrm{N}=$ & 5488 & $\mathrm{~N}=$ & 3869 & $\mathrm{~N}=$ & 1774 & $\mathrm{~N}=$ & 1131 & $\mathrm{~N}=$ & 1094 \\
\hline PT & 552 & $10.1 \%$ & 338 & $8.4 \%$ & 134 & $7.5 \%$ & 87 & $7.7 \%$ & 83 & $7.6 \%$ \\
\hline PDT & 347 & $6.3 \%$ & 230 & $5.7 \%$ & 124 & $7.0 \%$ & 88 & $7.8 \%$ & 56 & $5.1 \%$ \\
\hline PSB & 309 & $5.6 \%$ & 213 & $5.3 \%$ & 205 & $11.5 \%$ & 108 & $9.5 \%$ & 120 & $10.9 \%$ \\
\hline PMDB & 1182 & $21.5 \%$ & 864 & $21.6 \%$ & 331 & $18.6 \%$ & 207 & $18.3 \%$ & 203 & $18.5 \%$ \\
\hline $\mathrm{PP}$ & 538 & $9.8 \%$ & 410 & $10.2 \%$ & 118 & $6.6 \%$ & 84 & $7.4 \%$ & 85 & $7.8 \%$ \\
\hline PL/PR & 376 & $6.8 \%$ & 277 & $6.9 \%$ & 124 & $7.0 \%$ & 88 & $7.8 \%$ & 102 & $9.3 \%$ \\
\hline PTB & 407 & $7.4 \%$ & 297 & $7.4 \%$ & 180 & $10.1 \%$ & 122 & $10.8 \%$ & 118 & $10.8 \%$ \\
\hline GOVERNI STAS & 3711 & $67.6 \%$ & 2629 & $65.6 \%$ & 1216 & $68.5 \%$ & 784 & $69.3 \%$ & 767 & $70.0 \%$ \\
\hline PFL & 491 & $8.9 \%$ & 365 & $9.1 \%$ & 155 & $8.7 \%$ & 93 & $8.2 \%$ & 98 & $8.9 \%$ \\
\hline PSDB & 798 & $14.5 \%$ & 550 & $13.7 \%$ & 197 & $11.1 \%$ & 131 & $11.6 \%$ & 131 & $12.0 \%$ \\
\hline $\begin{array}{l}\text { NÃO } \\
\text { GOVERNI STAS }\end{array}$ & 1289 & $23.5 \%$ & 915 & $22.8 \%$ & 352 & $19.8 \%$ & 224 & $19.8 \%$ & 229 & $20.9 \%$ \\
\hline TOTAL & 5000 & $91.1 \%$ & 3544 & $88.5 \%$ & 1568 & $88.3 \%$ & 1008 & $89.0 \%$ & 996 & $90.9 \%$ \\
\hline
\end{tabular}

Fontes: TSE (resultados eleitorais) e IBGE (população, IDH e PIB municipal). 
Em 2008, já como DEM, as características da performance do partido nas eleições municipais se alteraram drasticamente. O primeiro ponto a destacar é a queda acentuada do total de prefeitos eleitos pelo partido, movimento que já se vislumbrava em 2004. A novidade é que essa queda ocorre principalmente nos segmentos nos quais, até então, o partido se saia melhor, isto, as cidades menores, localizadas no Nordeste, pouco desenvolvidas e muito dependentes do setor público. O desempenho do partido tornou-se praticamente uniforme. Deixou de haver diferença entre a sua participação no total de prefeitos eleitos e a verificada nos segmentos destacados.

Tabela III.6 - Desempenho relativo dos partidos nas eleições municipais

\begin{tabular}{|c|c|c|c|c|}
\hline & \multicolumn{4}{|c|}{2000} \\
\hline & $\begin{array}{c}\text {-20 MI L HABI TANTES } \\
(\mathrm{I})\end{array}$ & $\begin{array}{c}\text { NORDESTE } \\
\text { (II) }\end{array}$ & $\begin{array}{l}\text { I DH BAI XO } \\
(\text { III) }\end{array}$ & $\begin{array}{l}\text { APU/ PI B ALTO } \\
\text { ( I V) }\end{array}$ \\
\hline PFL & 1,07 & 1,33 & 1,33 & 1,31 \\
\hline PSDB & 0,98 & 0,91 & 0,89 & 0,92 \\
\hline PMDB & 1,06 & 0,88 & 0,93 & 0,97 \\
\hline PP & 1,06 & 0,76 & 0,87 & 0,83 \\
\hline PTB & 0,97 & 1,00 & 1,04 & 1,00 \\
\hline GOVERNI STAS & 1,04 & 0,99 & 1,02 & 1,02 \\
\hline PT & 0,68 & 0,35 & 0,23 & 0,46 \\
\hline PDT & 0,94 & 0,51 & 0,61 & 0,70 \\
\hline PL & 0,98 & 1,35 & 1,31 & 1,12 \\
\hline PSB & 0,77 & 1,63 & 1,20 & 1,70 \\
\hline \multirow[t]{3}{*}{ NÃO GOVERNI STAS } & 0,86 & 0,89 & 0,82 & 0,92 \\
\hline & \multicolumn{4}{|c|}{2004} \\
\hline & -20 MI L HABI TANTES & NORDESTE & I DH BAIXO & APU ALTO \\
\hline PT & 0,87 & 0,49 & 0,58 & 0,66 \\
\hline PDT & 0,98 & 0,47 & 0,59 & 0,68 \\
\hline PSB & 0,93 & 1,89 & 1,79 & 2,23 \\
\hline PMDB & 1,03 & 1,05 & 0,82 & 0,78 \\
\hline PP & 1,04 & 0,70 & 0,62 & 0,64 \\
\hline PL & 1,01 & 0,84 & 1,29 & 1,33 \\
\hline PTB & 0,99 & 0,97 & 1,11 & 1,09 \\
\hline GOVERNI STAS & 0,99 & 0,88 & 0,88 & 0,91 \\
\hline PFL & 1,04 & 1,62 & 1,54 & 1,42 \\
\hline PSDB & 0,95 & 0,83 & 0,83 & 0,89 \\
\hline \multirow[t]{3}{*}{ NÃO GOVERNI STAS } & 0,99 & 1,21 & 1,16 & 1,14 \\
\hline & \multicolumn{4}{|c|}{2008} \\
\hline & -20 MI L HABI TANTES & NORDESTE & I DH BAI XO & APU ALTO \\
\hline PT & 0,84 & 0,75 & 0,76 & 0,75 \\
\hline PDT & 0,91 & 1,10 & 1,23 & 0,81 \\
\hline PSB & 0,94 & 2,05 & 1,70 & 1,95 \\
\hline PMDB & 1,00 & 0,87 & 0,85 & 0,86 \\
\hline PP & 1,04 & 0,68 & 0,76 & 0,79 \\
\hline PL/PR & 1,01 & 1,02 & 1,14 & 1,36 \\
\hline PTB & 1,00 & 1,37 & 1,45 & 1,45 \\
\hline GOVERNI STAS & 0,97 & 1,01 & 1,02 & 1,04 \\
\hline DEM & 1,02 & 0,98 & 0,92 & 1,00 \\
\hline PSDB & 0,94 & 0,76 & 0,80 & 0,82 \\
\hline NÃO GOVERNI STAS & 0,97 & 0,84 & 0,84 & 0,89 \\
\hline
\end{tabular}


Isso pode ser mais bem visualizado na Tabela III.6 a qual apresenta um índice que compara o desempenho relativo dos partidos no total de municípios e nas amostras selecionadas segundo os critérios já explicados. Esse índice foi obtido por meio da divisão do percentual representativo da participação de cada partido em cada um dos segmentos pelo percentual obtido no total das prefeituras. Assim, os números da coluna I da Tabela III.6 foram obtidos por meio da divisão da coluna II pela coluna I da Tabela III.5; os da coluna II da Tabela III.6 são resultantes da divisão da coluna III pela coluna I da Tabela III.5; e assim sucessivamente. Quanto mais próximos de 1 forem os números da Tabela III.6, mais uniforme foi o desempenho do partido. Se o índice for maior do que 1 , significa que a legenda se sai melhor nos municípios que qualificamos como de viés governista do que no conjunto geral. Ocorre o inverso quando o índice é menor do que 1. Neste caso, o desempenho do partido é relativamente melhor nos municípios não caracteristicamente governistas.

No caso do PFL, os índices quase sempre estão significativamente acima de 1 em 2000 e 2004 (a exceção ocorre no grupo de municípios com menos de 20 mil habitantes), mas praticamente se igualam a 1 em 2008, o que demonstra que o partido, oito anos após ter se afastado do poder, enfraqueceu-se especialmente em sua tradicional base política, composta pelos municípios nordestinos, pouco desenvolvidos e dependentes do setor público. A queda de rendimento foi generalizada. Porém, foi mais aguda justamente onde o partido era, até então, mais forte.

Os números relativos aos demais partidos, embora indiquem que as categorias governista ou não governista explicam apenas parcialmente o desempenho das legendas nas eleições municipais, corroboram a ideia de que um partido tende se sair melhor nos municípios de viés governista quando faz parte da coligação que sustenta o governo federal. Os casos do PSDB, PT e PSB subsidiam essa afirmação.

Quanto ao PSDB e ao PT, os números mostram que essas duas legendas, ao contrário do PFL, são relativamente mais fracas nos grupos de municípios selecionados (- 20 mil habitantes, Nordeste, IDH baixo e APU/PIB alto). Seus índices ficaram consistentemente abaixo de 1 independentemente de estarem ou não no poder nacional. Isto certamente é decorrência da gênese dos dois partidos, que nasceram e se desenvolveram tendo como principal base a região Sudeste, principalmente o estado de São Paulo.

Os índices são especialmente modestos para o PT, cujo desempenho é marcantemente ruim nos municípios que fazem parte dos segmentos destacados nas Tabelas III.5 e III.6. Aliás, os resultados do PT nas eleições municipais, embora tenham melhorado ao longo do tempo, especialmente após o partido ter assumido o poder federal, são claramente menos positivos do que os obtidos pelo partido nas outras disputas eleitorais. 
Contudo, voltando à situação do PT e do PSDB, os números da Tabela III.6 mostram que os índices do PT subiram nas eleições de 2004 e 2008 e se aproximaram de 1, enquanto os índices do PSDB caíram e se tornaram ainda mais distantes de 1. Ou seja, após o PT ter substituído o PSDB na Presidência da República, aumentou a força eleitoral do petismo nos municípios menores, nordestinos, pouco desenvolvidos e dependentes do setor público, ao passo que o PSDB perdeu espaço nesses municípios, não tanto quanto o PFL, mas ainda assim de maneira significativa.

Vejamos agora o que aconteceu com o PSB. Os socialistas, assim como os pefelistas, sempre tiveram desempenho melhor nos municípios do Nordeste, de baixo IDH e alto APU/PIB. Seus índices sempre ficaram acima de 1. Porém, de 2000 para 2004 e 2008, ou seja, depois de o PSB ter chegado ao poder federal como um dos principais aliados do PT, quase todos os seus índices subiram e se distanciaram ainda mais de 1 . Isso significa que o PSB se tornou ainda mais forte nos municípios que qualificamos como governistas.

Os índices do PT, do PSDB e, em especial, do PFL mostram que a mudança no perfil do desempenho desses partidos nas eleições municipais acentuou-se de 2004 para 2008. Isso indica que 2004 pode ter sido uma eleição de transição para a nova conformação política decorrente da chegada do PT ao poder. De fato, essa eleição ocorreu apenas um ano e nove meses após a posse do presidente Lula na Presidência da República, tempo insuficiente para influenciar significativamente o balanço de poder na esfera municipal. Ademais, em 2004, o Bolsa Família, programa que seguramente deu grande impulso à popularidade de Lula e de seu governo nos municípios menos desenvolvidos e no Nordeste, dava ainda os seus primeiros passos. Como ilustraram as declarações de dirigentes do PFL citadas nesta dissertação, foi justamente a partir de 2004 que o PT e seus aliados começaram a avançar mais fortemente sobre a base eleitoral tradicional do partido.

O melhor desempenho relativo do PT - na verdade, mais de Lula do que do PT - junto ao eleitorado mais pobre se manifestou com nitidez na eleição presidencial de 2006, como destacam Singer (2009) e Zucco (2008 e 2010). Ambos concordam que o Bolsa Família e a política de aumento real do salário mínimo adotada por Lula - Singer destaca também o crédito consignado - foram importantes para que o petista conquistasse apoio dos eleitores mais pobres. Mas Singer lança mão também de um argumento de cunho sociológico para explicar a ampliação do lulismo nas camadas de renda mais baixa. Segundo ele, a manutenção da ordem econômica e social durante o governo Lula foi fundamental para a adesão do que ele chama de "subproletariado" ao lulismo, pois este segmento seria avesso à crispação social. Já Zucco, no paper de 2010, destaca, como já vimos, a importância do viés governista existente nas regiões mais pobres do país. Para ele, o fato de Lula ter ido relativamente melhor nessa parcela do eleitorado não é uma novidade. É a mera repetição do "incumbency effect". O não 
usual, segundo Zucco, foi o desempenho de Lula entre os habitantes mais pobres das regiões mais desenvolvidas do país, para os quais haveria evidências de que historicamente apresentam viés anti-governista. Embora diferentes, as explicações de Singer e Zucco não são antagônicas. Podem ser consideradas complementares. E ambos estão de acordo que, de 2002 para 2006, houve mudança da base de votação de Lula, que se tornou proporcionalmente maior nas áreas mais pobres do país e entre os eleitores de menor renda. Nas eleições locais, esse fenômeno parece ter se manifestado com força apenas em 2008, o que se pode visualizar a partir da análise dos índices do PT, PSDB e PFL apresentados na Tabela III.6.

Por fim, para finalizar a análise descritiva dos dados, o recuo do PFL/DEM e do PSDB no Nordeste e o avanço concomitante e proporcional dos partidos que passaram a ser governistas a partir de 2003 (PT, PSB, PCdoB e PL/PR) são bastante visíveis na Tabela 1II.7, a qual apresenta o total de prefeituras conquistadas por esses partidos nas últimas três eleições locais. Em 2008, quando, segundo nossa avaliação, ocorreu de maneira mais significativa o ajuste do poder político municipal à substituição do PSDB pelo PT na Presidência da República, o número de prefeituras perdidas por PSDB e PFL/DEM foi praticamente igual às conquistadas pelos novos governistas. Como se pode ver na última coluna da Tabela III.7, a diferença foi de apenas 8 prefeituras. PT e PSB foram os que mais se aproveitaram do enfraquecimento de PFL/DEM e PSDB na região. Somados, esses dois partidos ganharam 249 prefeituras na região. Em termos proporcionais, o número de prefeitos nordestinos petistas mais do que quintuplicou, enquanto as prefeituras controladas pelo PSB praticamente dobraram.

Tabela III.7 - Prefeitos eleitos por partidos governistas e não governistas no Nordeste

\begin{tabular}{|l|c|c|c|c|c|c|}
\hline & 2000 & 2004 & 2008 & $2004-2000$ & $2008-2004$ & $2008-2000$ \\
\hline PFL/DEM & 439 & 411 & 154 & -28 & -257 & -285 \\
\hline PSDB & 288 & 232 & 197 & -56 & -35 & -91 \\
\hline TOTAL & 727 & 643 & 351 & -84 & -292 & -376 \\
\hline \hline PT & 21 & 65 & 134 & 44 & 69 & 113 \\
\hline PSB & 70 & 107 & 206 & 37 & 99 & 136 \\
\hline PDT & 46 & 54 & 124 & 8 & 70 & 78 \\
\hline PCdoB & 1 & 7 & 36 & 6 & 29 & 35 \\
\hline PL/PR & 102 & 142 & 124 & 40 & -18 & 22 \\
\hline TOTAL & 240 & 375 & 624 & 135 & 249 & 384 \\
\hline
\end{tabular}

Fonte: TSE

Testes de média para as variáveis população, IDH e APU/PIB também indicam que há diferença entre o desempenho dos partidos governistas e não governistas nesses segmentos. Os testes foram feitos para todos os partidos e, posteriormente, apenas para o PFL/DEM, quando este fazia parte da coligação governista e após ter ido para a oposição. Excluímos da 
amostra a eleição de 2004, pois, como argumentamos acima, ela parece ter sido uma eleição de transição. Os resultados estão na Tabela III.8. Os testes mostraram de maneira estatisticamente consistente que tanto para o conjunto dos partido, como para o PFL: 1) a média da população dos partidos governistas é menor do que a dos não governistas; 2) O IDH dos governistas é menor; 3) a relação APU/PIB é maior para os governistas.

Tabela III .8 - Testes de média, partidos governistas e não governistas

\begin{tabular}{|c|c|c|c|c|c|c|}
\hline & \multicolumn{2}{|c|}{$\mathrm{IDH}$} & \multicolumn{2}{|c|}{ População } & \multicolumn{2}{|c|}{ APU/PIB } \\
\hline & Governistas & $\begin{array}{c}\text { Não } \\
\text { governistas }\end{array}$ & Governistas & $\begin{array}{c}\text { Não } \\
\text { governistas }\end{array}$ & Governistas & $\begin{array}{c}\text { Não } \\
\text { governistas }\end{array}$ \\
\hline $\begin{array}{l}\text { Todos os } \\
\text { partidos }\end{array}$ & $0,698 * *$ & $0,702 * *$ & $28.562 *$ & $41.101^{*}$ & $0,266^{*}$ & $0,260 *$ \\
\hline PFL/DEM & $0,677^{*}$ & $0,701 *$ & $23.135^{* * *}$ & $45.009 * * *$ & 0,292* & $0,266^{*}$ \\
\hline
\end{tabular}

Apresentaremos agora os modelos estatísticos. A variável dependente é o desempenho dos partidos - medido pela eleição de seu candidato e não pela quantidade de votos obtidos pelo partido - nos pleitos 2000 e 2008. Pelas razões já explicadas, excluímos da amostra os dados da eleição de 2004. Como estamos interessados em avaliar o efeito da mudança do status dos partidos - de governista para não governista e vice-versa -, excluímos também as prefeituras conquistadas pelo PMDB, PP e PTB pois a condição desses partidos não se alterou na transição do governo tucano para o petista. Eram e continuaram sendo partidos governistas. Assim, para fins dos modelos estatísticos aqui apresentados, apenas PSDB e PFL foram considerados governistas em 2000, enquanto PT, PSB, PDT e PL/PR são os não governistas. Já a partir de 2004, invertem-se essas condições: PT, PSB, PDT e PL/PR são governistas e PSDB e DEM passam a ser não governistas. Os partidos foram tratados como uma variável binária. Foi atribuído valor 1 para os governistas e 0 para os não governistas. As variáveis independentes do modelo são: 1) a população do município; 2) IDH municipal; 3) relação APU/PIB; e 3) uma dummy de localização regional do município: 1 para os municípios nordestinos e 0 para os demais.

Os dados foram tratados por modelos estatísticos de tipo probit. ${ }^{62}$ No primeiro deles estão presentes todas as variáveis. Nos modelos seguintes foram tratadas apenas uma variável por vez, acompanhada da constante. Em todos os modelos, as variáveis apresentam coeficientes com os sinais esperados, com exceção da variável APU/PIB no Modelo 1. Os coeficientes indicam que há relação inversa entre o desempenho dos partidos governistas e (a) o tamanho da população dos municípios (Modelo 5) e (b) o valor do IDH (Modelos 1 e 2). Ou seja, quanto menor e menos desenvolvido for o município, maior a chance de um partido governista eleger o prefeito. Os coeficientes mostram que a relação é direta nos casos da

\footnotetext{
${ }^{62}$ Para análise sobre as aplicações e características deste tipo de modelo ver Wooldridge (2003: 554-565).
} 
dummy regional (Modelo 3) e do APU/PIB (Modelo 4). Isto significa que, a chance de um partido governista eleger o seu candidato a prefeito é maior nos municípios localizados no Nordeste e com elevada relação APU/PIB. São resultados coerentes com os números apresentados nas Tabelas III.5 e III.6 e também com os teste de média.

Tabela I I .9: Resultados modelos estatísticos

\begin{tabular}{|c|c|c|c|c|c|}
\hline Constante & Modelo 1 & Modelo 2 & Modelo 3 & Modelo 4 & Modelo 5 \\
\hline IDH & $\begin{array}{c}1,103^{*} \\
(0,292)\end{array}$ & $\begin{array}{c}1,036^{*} \\
(0,133)\end{array}$ & $\begin{array}{c}0,064^{*} \\
(0,019)\end{array}$ & $\begin{array}{c}-0,039^{*} \\
(0,034)\end{array}$ & $\begin{array}{c}0,127^{*} \\
(0,016)\end{array}$ \\
\hline População & $\begin{array}{c}-1,386^{*} \\
(0,361)\end{array}$ & $\begin{array}{c}-1,319^{*} \\
(0,189)\end{array}$ & -- & -- & -- \\
\hline APU/PIB & $\begin{array}{c}-8,89 \mathrm{e}-08 \\
(6,72 \mathrm{e}-08)\end{array}$ & -- & -- & -- & $\begin{array}{c}-1,95 \mathrm{e}-08^{*} \\
(9,77 \mathrm{e}-08)\end{array}$ \\
\hline Dummy regional & $\begin{array}{c}-0,540 \\
(0,177)\end{array}$ & -- & -- & $0,588^{*}$ & -- \\
$(0,006$ & -- & $\begin{array}{c}0,162^{*} \\
(0,032)\end{array}$ & -- & -- \\
\hline
\end{tabular}

$\mathrm{N}=6.612$

OBS: valores em parênteses indicam o desvio padrão das variáveis.

* Significativo a $1 \%$.

No modelo com todas as variáveis (Modelo 1), apenas o coeficiente da variável IDH foi estatisticamente significante. Uma possível explicação para a insignificância estatística dos coeficientes das variáveis população, dummy regional e APU/PIB no Modelo 1 é a existência de multicolinearidade entre elas e entre essas e o IDH. Se há multicolinearidade, não se sustenta o pressuposto de independência entre as variáveis exógenas. Assim, embora conjuntamente, as variáveis expliquem o modelo, individualmente são estatisticamente insignificantes. ${ }^{63}$

A mais forte indicação de que há multicolinearidade entre essas variáveis é o fato de seus coeficientes, ao contrário do modelo completo (Modelo 1), terem se mostrado estatisticamente significativos quando cada uma delas foi tratada isoladamente (Modelos 3, 4 e 5). Outra indicação de que há multicolinearidade entre essas variáveis é que $89,2 \%$ dos municípios que definimos como de IDH baixo (menor que 0,616 ) estão localizados no Nordeste e 76,3\% dos municípios de APU/PIB alto (maior que 0,403) também são nordestinos. Ou seja, a grande maioria dos municípios com tais características está no Nordeste. Os números da Tabelas III.5 e III.6 também mostram evidências de que há multicolinearidade pelo menos entre as variáveis Nordeste, IDH e APU/PIB. Nas tabelas, é possível verificar que os percentuais e os índices da maioria dos partidos são bastante semelhantes para o Nordeste, IDH baixo e APU/PIB alto. Por exemplo, os percentuais do PFL nesses segmentos foram, respectivamente, de $24,7 \%, 24,7 \%$ e $24,4 \%$ em $2000 ; 23,1 \%, 21,9 \%$ e $20,3 \%$ em 2004 ; e de $9,1 \%, 8,7 \%$ e $8,2 \%$ em 2008 . Esse padrão de semelhança se repete para a maioria dos demais partidos.

\footnotetext{
${ }^{63}$ A respeito dos efeitos da multicolinearidade sobre regressões múltiplas, ver Wooldridge (2003: 97-100).
} 
Feitas essas considerações a respeito da multicolinearidade, pode-se dizer que os resultados dos modelos estatísticos parecem bastante robustos, especialmente para o IDH. Estão também alinhados com os exercícios estatísticos realizados por Zucco (2010), os quais o levaram a concluir que o candidato presidencial incumbente, nas eleições de 1994 a 2010, sempre se saiu relativamente melhor nos municípios de menor IDH.

Sumarizando as conclusões que podem ser extraídas a partir da analise descritiva dos dados apresentados nas Tabelas III.5, 111.6 e 111.7 dos testes de média e dos modelos estatísticos, pode-se afirmar que:

1) os partidos governistas têm melhor desempenho eleitoral nos municípios menos desenvolvidos (IDH), economicamente mais dependentes do setor público (relação APU/PIB), localizados no Nordeste e menos populosos. As indicações são mais robustas para o IDH e menos para a população;

2) consequentemente, pode-se inferir que há municípios que possuem viés governista;

3) 2004 parece ter sido uma eleição de transição. O ajuste local à chegada do PT ao poder federal parece ter ocorrido de maneira mais significativa apenas em 2008;

4) a transição do PFL para a oposição acarretou acentuado declínio do desempenho do partido nos municípios que parecem ter viés governista.

Tais conclusões reforçam a avaliação de que os dois movimentos que provocaram o enfraquecimento do partido - a saída de parlamentares e o mau desempenho eleitoral nas cidades de perfil governista - estavam interconectados e se retroalimentaram. Afinal, ambos ocorreram com mais intensidade no Nordeste, onde o PFL foi mais forte durante a sua fase governista. 


\section{Conclusão}

"Terno branco, sapato de duas cores e oposição só é bonito nos outros" Frase atribuída ao deputado Inocêncio de Oliveira (PR-PE), que deixou o PFL em fevereiro de $2005 .{ }^{64}$

O anúncio de que o PFL mudaria de nome foi recebido com indisfarçável enfado pela imprensa política nacional. O sentimento era justificado. Não era a primeira vez que se assistia no Brasil a um partido em crise tirar da manga a carta da mudança de nome, como se isso, num passe de mágica, pude-se resolver as dificuldades da legenda. Tal estratégia foi especialmente usual na trajetória do atual PP, com quem o PFL partilha uma raiz histórica comum. São galhos da mesma árvore: a outrora poderosa ARENA - que chegou a ser classificada nos anos 70 por seu então presidente, Francelino Pereira, como o "maior partido do Ocidente" - esteio político dos governos militares entre 1965 e 1979. Antes de ser PP, o partido foi PDS, PPR e PPB. Portanto, até pelo exemplo dado por seu primo próximo, digamos assim, era inevitável a sensação de déjà vu diante da notícia de que o PFL também trocaria de nome.

Além de tédio, o anúncio da troca de nome suscitou também um comentário frequente. Dizia-se amiúde que a operação seria apenas uma "jogada de marketing" dos dirigentes do partido que o estariam "repaginando" a fim de camuflar o seu pecado original - o apoio ao regime militar - e outras nódoas acumuladas ao longo de sua existência. De fato, como foi destacado no segundo capítulo desta dissertação, um dos objetivos do chamado processo de refundação do PFL foi sim apagar a sua ligação com a ditadura militar de 64. Pretendia-se também dar ao partido uma nova imagem pois, como mostrou fartamente a pesquisa realizada pela $\mathrm{MCl}$, a opinião da maioria da opinião pública a respeito do PFL era francamente negativa. Portanto, de certa maneira, foi realmente uma jogada de marketing. Mas essa é apenas a face mais evidente desse processo que, como tentamos mostrar na dissertação, apresenta contornos mais interessantes a serem explorados.

A chave para ir além da abordagem "apenas uma jogada de marketing" está no evento que levou os dirigentes pefelistas a se empenharem no processo de refundação do partido. Esse evento foi a eleição de Lula para a Presidência da República e a conseqüente chegada do PT ao poder federal. Foi um acontecimento marcante para o país e também decisivo para a trajetória do PFL, que, pela primeira vez em sua história, viu-se desabrigado do poder nacional. Assumimos como hipótese central deste trabalho justamente a ideia de que a

\footnotetext{
64 “Em PE, Campos fecha com prefeitos do PSDB e do DEM”, matéria assinada pelo jornalista Murillo Camarotto, Jornal Valor, 22/04/2010.
} 
passagem do PFL para a oposição foi o fator desencadeador do processo de refundação do partido, o qual culminou no surgimento do DEM. Há que se reconhecer que esta não é uma hipótese nem muito original nem muito ousada, a exigir extenuantes e complexas análises e tratamentos de dados e informações a fim de ser comprovada. Para isto, bastariam as entrevistas que realizamos com políticos e com pessoas ligadas ao partido, nas quais essa ideia foi reiteradamente confirmada, como serve de exemplo a epígrafe que abre o terceiro capítulo desta dissertação.

Mas, se não é uma hipótese muito impactante, acreditamos que ela, em contrapartida, nos permitiu extrair da refundação do PFL alguns elementos interessantes para as lentes da ciência política brasileira. Foi o que tentamos fazer na dissertação, quando mostramos os estragos que a passagem à oposição provocou no PFL. O efeito mais imediato foi a perda de parlamentares eleitos pelo partido que, em sua grande maioria - muitos antes mesmo da posse - rumaram para legendas aliadas ao governo petista ou manifestamente sedentas por uma oportunidade de se aproximar do novo grupo instalado no poder federal. A esse movimento inicial seguiu-se o progressivo encolhimento eleitoral do partido. Nos dois casos, a perda foi maior no Nordeste, região onde o PFL era mais forte, mas que também, conforme argumentamos no Capítulo 3, parece ser uma área mais sujeita à influência do governismo federal.

Utilizando os dados das eleições para prefeito em 2000, 2004 e 2008, encontramos também evidências de que as condições governista e não governista, definidas em função do grupo que ocupa o poder nacional, estão relacionadas a perfis diferentes de desempenho dos partidos nas disputas municipais. Os partidos governistas parecem se sair relativamente melhor nos municípios de menor população, menos desenvolvidos, mais economicamente dependentes do setor público e localizados no Nordeste. Outra maneira de encarar esse resultado, seria dizer que os municípios com tais características apresentam um viés governista.

Para usar uma expressão empregada por Zucco (2010: 3), que, embora trabalhe com dados das eleições presidenciais, chegou a resultado semelhante ao nosso, esse "progovernment bias in poor places in the country (...) remains an empirical regularity in search of a theory".

Naturalmente, não temos a pretensão de preencher tal lacuna teórica nesta dissertação. Podemos apenas fazer eco ao apelo feito por Zucco a favor de uma teoria que explique tal fenômeno e que esteja afinada com a situação contemporânea do país, visto que o patrimonialismo de Faoro (1958), o neopatrimonialismo e a cooptação política de Schwartzman (1982) e o coronelismo de Leal (1978 [1949]), que poderiam nos ajudar na fundamentação 
teórica desse fenômeno, tratam de um Brasil bastante diverso do atual. Necessitamos, em especial, de um novo "Coronelismo, enxada e voto".

O próprio Zucco, apesar de demandar uma explicação teórica, arrisca, como ele mesmo diz, algumas conjecturas. Segundo ele, "one way to rationalize a geography-base mechanism is that voters, and poor voters in particular, are responding to the delivery of tangible benefits, either directly in the form of pensions, benefits, in kind transfer to voters, or indirectly as through support for local projects and programs" (2010: 20). Assim, a hipótese lançada por Zucco é que a ação do governo federal é o elemento que explica tais relações. O Bolsa Família seria o exemplo mais visível, mas "it is probably the case that other policies, formal or informal, were playing the same role in previous periods, though probably less efficiently" (Idem). Assim, o fato de que "all else equal, incumbent candidates perform better in poorer places" é uma evidência de que estes possuem "greater ease to reach voters in poorer places or, conversely, greater difficulties by the opposition to reach them, and the reason might simply be that local government in poor places depend on the Federal government, and are willing to align themselves with the incumbent to increase their access to resources" (Ibidem: 22). É uma explicação que, como admite o próprio Zucco, remete à boa e velha teoria do clientelismo, e que é corroborada por declarações dos pefelistas colhidas nas entrevistas, como esta, que apresentamos no Capítulo 3: "aproximar-se do governo [federal] é uma necessidade. Muitos municípios não conseguem sobreviver sem aderir ao poder" (José Carlos Aleluia, em entrevista ao autor).

Essa discussão nos permitiu resgatar uma questão recorrente na ciência política brasileira: a força e a importância do aparelho estatal no Brasil, tema de grande centralidade nas obras de Faoro (1958), Schwartzman (1982) e Souza (1976), para ficarmos com autores abordados nesta dissertação. E mostra, por outro lado, que os dirigentes do PFL partiram de um diagnóstico correto a respeito do que ocorreria com o partido após a sua passagem para a oposição. Sabiam que o partido minguaria justamente onde era mais forte, no Nordeste e nos chamados grotões. Daí o empenho em "refundar" o partido, movimento que, sob esse ponto de vista, não deve ser confundido com uma "simples jogada de marketing".

Contudo, quatro anos após o seu surgimento, o DEM definha em praça pública. O partido não conseguiu compensar a queda no seu reduto tradicional com a ascensão em outras regiões e a conquista de um novo tipo de eleitorado. Ficou, dessa maneira, ainda mais distante do objetivo enunciado por Jorge Bornhausen de fazer do PFL uma versão brasileira do PP espanhol ou do PSD português. Os dirigentes do partido não lograram levar adiante o que seria o grande "projeto do PFL" ${ }^{65}$ : construir um partido liberal conservador e eleitoralmente

\footnotetext{
${ }^{65}$ Essa ideia do "projeto PFL” nos foi sugerida por Antônio Paim em entrevista que nos foi concedida em fevereiro de 2010, a quem agradeço a contribuição.
} 
competitivo no Brasil, capaz de representar segmentos da sociedade mais avessos ao ideário de esquerda ou de centro-esquerda e, a partir dessa base, ascender por suas próprias pernas ao poder nacional.

Não se pode dizer com segurança absoluta que tal projeto esteja definitivamente sepultado. Mas, em contrapartida, é possível asseverar que o processo de refundação exposto nesta dissertação fracassou de maneira retumbante. Quanto a isso cremos não existir dúvidas. A marca simbólica mais ilustrativa desse fracasso foi a saída de Jorge Bornhausen do partido em maio de 2011, quem foi o principal artífice e condutor do processo de refundação. Bornhausen anunciou que não se filiará a outro partido e que abandonou a política partidária. Porém, todo o seu grupo político, inclusive o seu filho, o deputado federal Paulo Bornhausen, saíram do DEM para se juntar ao futuro PSD. ${ }^{66}$

O surgimento do PSD, projeto político articulado por Gilberto Kassab, prefeito de São Paulo e, até o final de 2010, o demista de maior visibilidade no país, pode tirar o DEM do grupo de partidos relevantes do país e colocá-lo na companhia das diversas legendas pouco expressivas que habitam a política nacional. O PSD ameaça atrair cerca de 20 deputados federais do DEM, praticamente metade da bancada eleita em 2010, uma senadora (Kátia Abreu - TO), um dos dois governadores demistas (Raimundo Colombo - SC), um vicegovernador (Guilherme Afif Domingos - SP) e dezenas de deputados estaduais, prefeitos e vereadores. É temerário dizer que o DEM não irá se recuperar dessa verdadeira blitzkrieg desfechada pelo PSD contra suas fileiras. Mas é um revés que, caso seja confirmado, certamente contribuirá para reforçar os prognósticos pessimistas a respeito do futuro do partido.

É interessante notar que essa ação do PSD pode representar o fecho do ciclo de decadência do PFL/DEM, que começou e pode terminar da mesma maneira, com a saída expressiva de políticos na direção de uma legenda de perfil mais governista. Na avaliação do governador pernambucano Eduardo Campos sobre o PSD, em entrevista ao jornal Valor (13/05/2011), "o conjunto de forças que sempre esteve no governo, ao cabo de oito anos fora dele, resolveu mudar para ser o que sempre foi: base do governo". Enfim, fechou-se um ciclo. E este ponto, ressaltado pela frase de Eduardo Campos, é relevante para esta dissertação. Mostra a força do governismo no Brasil.

Uma das explicações para o provável sucesso da criação do PSD, que deve nascer como um partido de porte médio para os padrões brasileiros, é justamente o manifesto viés governista do partido. Como escreveu Gilberto Kassab em artigo no jornal Folha de S. Paulo

\footnotetext{
${ }^{66}$ No momento da finalização desta dissertação (julho de 2011), a criação do PSD esta ainda pendente do cumprimento das exigências da legislação partidária, em especial, da obtenção da assinatura de 490 mil eleitores. Tudo indica, contudo, que, mais cedo ou mais tarde, tais assinaturas serão obtidas.
} 
(16/05/2011), “o PSD não fará oposição pela oposição" e nasce para "buscar consensos" e para "somar esforços para construir o bem comum". Segundo se depreende das declarações de futuros pessedistas à imprensa e de notícias sobre o partido, essa repulsa à "oposição pela oposição" e a busca de consensos e do "bem comum" não se limitará à esfera federal. Deverá se estender também aos estados. Assim, o PSD, provavelmente, além de apoiar o governo Dilma Rousseff, será aliado do PSDB, em Minas Gerais e no Paraná (e talvez até em São Paulo); do PT na Bahia; do PMDB no Rio de Janeiro e no Maranhão; do PSB em Pernambuco e assim por diante. Ou seja, tal como o seu homônimo do período 45-64, o atual PSD pretende ser uma "ostra incrustada no casco da nau do Estado" (ver nota 27, do Capítulo 1). A fórmula para a criação do partido se complementa com a dispensa de qualquer veleidade ideológica. $O$ PSD, anunciou Kassab à imprensa no final de março de 2011, "não será de direita, não será de esquerda, nem de centro".

Do ponto de vista da discussão teórica feita no Capítulo 1, o fracasso da refundação do PFL e a "fórmula PSD" nos remete à ideia formulada por Mair de que os partidos contemporâneos reforçaram sua conexão com o Estado e afrouxaram seus laços com a sociedade. A decorrência natural desse deslocamento é o rebaixamento da função representativa tradicionalmente desempenhada pelos partidos. Por outro lado, ao se aproximarem do Estado para retirar dele recursos políticos, mas também financeiros - verba pública de campanha, por exemplo -, a função governativa dos partidos ganhou força. Na organização interna dos partidos, resgatando os termos de Katz e Mair, pode-se dizer que a faceta party in the public office se sobrepôs ao party on the ground. Nas duas esferas, a relacionada às funções dos partidos e a organizacional, houve um perde e ganha. Portanto, à primeira vista, tais mudanças não servem para sustentar a ideia de que a instituição partido político está em crise na democracia contemporânea. Contudo, em uma segunda mirada, pode ser que haja sim um problema importante com esse tipo de partido, que Katz e Mair chamam de partido cartel. O próprio Mair (2009) levanta essa possibilidade em paper recente. Ele diz que a grande inovação institucional trazida pelos partidos à democracia foi a combinação das funções representativa e governativa. Os partidos se tornaram elemento essencial na engrenagem da democracia representativa moderna porque lograram combinar esses dois papéis. Continuarão a ser tão relevantes e centrais se perderem a função representativa? É a questão deixada por Mair. ${ }^{67}$

Voltando ao PFL, a construção abstrata feita por Katz e Mair - e por este último isoladamente no paper citado acima - fornece, a nosso juízo, uma boa descrição da história da

\footnotetext{
${ }^{67}$ Nesse mesmo paper, Mair formula outra ideia interessante. A disjunção entre as funções representativas e governativas parece estar criando dois tipos de partidos. Os que governam, mas mantém uma conexão débil com a sociedade e os que representam, mas não governam. É o que ele chama de processo de bifurcação dos partidos. Na Europa, os que apenas representam, seriam principalmente os partidos populistas de direita.
} 
decadência pefelista. Para começar, assim como Tarouco (1999), acreditamos que, até migrar para a oposição, o PFL se encaixava no perfil de partido cartel. Ajustando pelas especificidades do contexto brasileiro, poderíamos dizer que, usando Mair (2009), cumpria bastante bem a sua função governativa. Quando passou à oposição, faltou-lhe, contudo, uma base - algo tão cobiçado pelo senador Marco Maciel ${ }^{68}$. A sua base tradicional não era, para recuperar um termo um pouco fora de moda, orgânica ao partido. Como dizem Mainwaring, Meneguello e Power (2000), a falta de bases coerentes com o seu ideário político seria uma característica típica dos partidos conservadores brasileiros. Segundo eles, "os partidos de direita [no Brasil] foram sempre criados e organizados de cima para baixo ${ }^{69}$. Os eleitores conservadores no Brasil nunca criaram um importante partido a partir de suas bases sociais, tampouco os partidos conservadores estabeleceram uma organização estruturada sobre uma base mobilizada". (Ibidem: 61) Um dos objetivos do processo de refundação foi justamente buscar uma base mobilizada que desse sustentação a um partido de centro-direita. Mas essa meta, até o momento pelo menos, não foi alcançada.

Em contrapartida, uma possibilidade não remota é que, ao final desse processo de encolhimento - se esse final não for a extinção do partido - o DEM acabe se acomodando no lado representacional da bifurcação apresentada por Mair. Terá passado de um partido governativo para um partido representacional, provavelmente assumindo com mais nitidez o seu perfil de direita. Se isso ocorrer, será estabelecido um interessante contraponto ao PSD, que nasce vocacionado a ser um partido governista e ao mesmo tempo "aideológico". Um partido "nem de esquerda, nem de direita, nem de centro", para usar a reveladora frase de Gilberto Kassab.

O projeto de refundação pretendia fazer com que o DEM pudesse ser capaz de representar e também se habilitar para, em algum momento, assumir de maneira plena a sua função governativa, como fez o PP espanhol. Não foi possível. O grupo rachou por motivos diversos, inclusive em decorrência da disputa pelo controle do partido. Uma parte, que resolveu privilegiar a função governativa e tende a ser numericamente majoritária, ruma para o PSD. A outra, minoritária, talvez fique com a parte representativa. Ou talvez se abrigue definitivamente no PSDB, legenda que, na comparação com o que restou do DEM, mantém mais chances de voltar ao poder.

O PSDB também encolheu na oposição. Mas manteve postos importantes de poder que, pensando em termos de um futuro mais próximo - até 2014, digamos -, o credenciam a ser tratado como o partido com mais chance de retirar o PT do poder. O melhor estado de saúde

\footnotetext{
${ }^{68}$ Ver epígrafe do Capítulo 1

${ }^{69}$ O próprio processo de refundação do PFL, que, como vimos no Capítulo 2, foi um projeto de “cima para baixo”, é uma evidência dessa afirmação.
} 
do PSDB em comparação ao DEM é consequência de vários fatores. O mais importantes provavelmente interconectados - talvez sejam o fato de os tucanos terem ocupado o poder nacional por oito anos, o que thes deu um estoque de recursos para que sobrevivessem às vacas magras da oposição, e o sucesso do partido em reter o governo de estados importantes, como São Paulo e Minas Gerais. Mas outra razão possível é que o PSDB, ao contrário do PFL, tinha e tem conexões mais sólidas com setores importantes da sociedade brasileira. Por exemplo, a classe média tradicional e o empresariado mais ligado às finanças e à agroindústria. São setores que, do ponto de vista geográfico, estão assentados principalmente no estado de São Paulo, o qual, não por acaso, está sob comando tucano há longos 17 anos.

Para a abordagem dos empiristas/relativistas apresentada no Capítulo 1, a eventual adesão dos despojos demistas ao PSDB seria absolutamente natural. Comporia o processo de consolidação e estruturação do sistema partidário brasileiro que teria como uma de suas engrenagens a polarização PT e PSDB. (Cortez e Limongi 2010)

O encolhimento do PFL também pode ser tomado como uma evidência do amadurecimento do sistema político partidário brasileiro sob o ponto de vista da adequação programática e ideológica entre diferentes segmentos sociais do eleitorado e os partidos que, teoricamente, os representam, ou deveriam representar. Nesse sentido, o fortalecimento do PT entre os mais pobres seria o ajustamento natural a uma situação mais coerente do ponto de vista da representação dos interesses. Tal como ocorre nas democracias mais maduras, os eleitores de menor renda passariam a constituir a base dos partidos de centro-esquerda e os eleitores mais abonados formariam a base dos partidos de centro-direita. Conforme Lipset $^{70}$ (1963 apud Mainwaring, Meneguello e Power, 2000: 69), “em praticamente todos os países economicamente desenvolvidos, os grupos de mais baixa renda votam principalmente nos partidos de esquerda, enquanto aqueles de renda mais alta votam principalmente nos partidos de direita".

A hipótese de que estaria em curso no Brasil um processo de adequação à situação que, de acordo com descrição de Lipset, caracterizaria a política dos países economicamente desenvolvidos, nos remete a outra espécie de explicação para as mudanças que ilustramos com os dados do Capítulo 3. Preliminarmente, pode-se dizer que há pontos a favor dessa explicação alternativa. Em primeiro lugar, ela se adequa ao que parecia estar ocorrendo ao final do período 45-64, quando, como discutimos no Capítulo 1, o PTB avançava nas pequenas e médias cidades, o PSD encolhia e a UDN tentava se consolidar como o partido das classes

\footnotetext{
${ }^{70}$ Lipset, Seymour M. (1963). Political Man: The Social Bases por Politic, Garden City, Nova York, Anchor Books, p. 234.
} 
médias urbanas. (Sousa, 1976 e Soares, 1974) ${ }^{71}$ Também há similaridade com o que ocorreu com o MDB a partir de meados da década de 80, quando parece ter assumido a imagem de "partido dos pobres". ${ }^{72}$ Desse modo, as transformações nas bases eleitorais partidárias locais abordadas nesta dissertação representariam a retomada de tendências que estariam se conformando no período 45-64 e que foram interrompidas pelo golpe militar. Tais tendências teriam se manifestado até durante a própria ditadura militar quando o MDB teria conquistado a apoio dos eleitores de menor renda. Por essas razões, essa narrativa diferente da que construímos nesta dissertação merece ser examinada com mais cuidado no futuro.

Porém, à primeira vista, ela não desqualifica a hipótese de que o governismo é um elemento relevante na política brasileira. Foi importante no passado e parece continuar a ser no presente, especialmente, como indicam a análise dos dados do Capítulo 3, nas localidades menos desenvolvidas do país.

\footnotetext{
${ }^{71}$ Essa, como já dissemos, não é a interpretação de Lima Jr (1983), segundo quem, a análise conjunta das eleições nacionais e estaduais não corrobora a tese da tendência de retração das legendas conservadoras ao final do período 4564.

${ }^{72}$ Ver Reis (2000)
} 


\section{REFERÊNCI AS BI BLI OGRÁFICAS}

ABRANCHES, Sérgio Henrique (1988). “O presidencialismo de coalizão: o dilema institucional brasileiro", in Dados 31(1), 1988, pp 5-33.

ABRÚCIO, Fernando Luiz. Os barões da federação: o poder dos governadores no Brasil pósautoritário. São Paulo: Hucitec; Departamento de Ciência Política - USP.

ALMEIDA, Ludmila Chaves (2004). PPB: Origem e Trajetória de um Partido de Direita no Brasil, Dissertação de Mestrado, Faculdade de Filosofia, Letras e Ciências Humanas da Universidade de São Paulo, Departamento de Ciência Política.

ALMEIDA, Maria Hermínia Tavares de e CARNEIRO, Leandro Piquet (2008). “Definindo a Arena Política Local: Sistemas Partidários Municipais na Federação Brasileira", Dados - Revista de Ciências Sociais, Rio de Janeiro, vol. 51, no. 2, 2008, pp 403 a 432.

AMES, Barry (1995a). "Constituency Pressures and Pork Barrel: Bases of Voting in the Brazilian Congress". J ournal of Politics 57, no. 2, 324-43.

AMES, Barry (1995b). "Electoral Strategy under Open-List Proportional Representation". American J ournal of Political Science 39, no. 2, 406-33.

AMORIM NETO, Octávio (2006), Presidencialismo e Governabilidade nas Américas. Rio de Janeiro: FGV Editora e Fundação Adenauer.

ANKERSMIT, F (2002). Political Representation. Stanford: Stanford University Press.

BALBACHEVSKY, Elizabeth e HOLZACHER, Denilde (2007) "Classe, Ideologia e Políticos: uma Interpretação dos Resultados das Eleições de 2002 e 2006", Opinião Pública, Campinas, vol. 13, no. 2, novembro.

BENEVIDES, Maria Vitória de Mesquita (1981). A UDN e o udenismo: ambigüidades do liberalismo brasileiro (1945-1965), São Paulo, Paz e Terra.

BRAGA, Maria do Socorro S. (2006). O processo partidário-eleitoral brasileiro: padrões de competição política (1982-2002). Associação Editorial Humanitas: FAPESP.

CAMPOS, Roberto Ramos (2002). "A Face de um Partido: base política e comportamento eleitoral do PFL Pernambuco, 1985-2001", Tese de Doutorado, Faculdade de Filosofia, Letras e Ciências Humanas da Universidade de São Paulo. Departamento de Ciência Política.

CANTANHÊDE. Eliane (2001). O PFL. Publifolha.

CARAMANI, D. e HUG, S (1998). Parties and Party Systems: A Bibliographical Guide to the Literature on Parties and Party Systems in Europe since 1945. London: Sage.

CARDOSO, Fernando Henrique (1975). “Partidos e Deputados em São Paulo. O Voto e a Representação Política", in Cardoso, F. H. e Lamounier, B (orgs). Os Partidos e as Eleições no Brasil. Rio de Janeiro, Editora Paz e Terra.

CARREIRÃO, Yan (2007). “Identificação I deológica, Partidos e Voto na Eleição Presidencial de 2006”, Opinião Pública, Campinas, novembro, vol 13, no. 2, pp 307-339.

CARREIRÃO, Yan (2008). “Opiniões Políticas e Sentimentos Partidários dos Eleitores Brasileiros”. Opinião Pública, Campinas, novembro, vol 14, no. 2, , pp 319-351. 
CORTEZ, Rafael e LIMONGI, Fernando (2010). "As Eleições de 2010 e o Quadro Partidário", Novos Estudos 88, novembro 2010.

DAALDER, Hans (2002). "Parties: Denied, Dismissed or Redundant? A Critique", in GUNTHER, R., LINZ, J. J. e MONTERO, J. R. Political Parties: Old Concepts and New Challenges, Oxford University Press, edição digital.

DALTON, R. J. e WATTEMBeRG, M (2000) (ed). Parties Without Partisans: Political Change in Advanced Industrial Democracies, Oxford, Oxford University Press.

DI MENSTEI N, Gilberto; FERNANDES, Roberto; LOPES, Roberto; NEGREIRO, J osé e NOBLAT, Ricardo (1985). O Complô que Elegeu Tancredo. Rio de Janeiro, Editora JB.

DUVERGER, Maurice (1970). Os Partidos Políticos. Rio de Janeiro: Zahar.

FAORO, Raymundo. (1958). Os Donos do Poder: Formação do Patronato Político Brasileiro. Rio de J aneiro / Porto Alegre / São Paulo, Editora Globo.

FIGUEIREDO, Argelina Cheibub e LIMONGI, Fernando (1995), "Partidos políticos na Câmara dos Deputados: 1989-1994". Rio de Janeiro, Dados, vol 38, no. 3.

FIGUEI REDO, Argelina Cheibub e LIMONGI, Fernando (1998). "Reforma da previdência e instituições políticas". Novos Estudos CEBRAP, no. 51, julho/1998.

FREITAS, Andréa (2008a). Migração Partidária na Câmara dos Deputados, Dissertação de Mestrado, Departamento de Ciência Política, Faculdade de Filosofia, Letras e Ciências Humanas da USP.

FREITAS, Andréa (2008b). "Infidelidade partidária e representação política: alguns argumentos sobre a migração partidária no Brasil". Caderno CRH, Salvador. V. 21, n. 52, p. 9-12, Jan-Abr. GUNTHER, Richard e HOPKIN, J onathan (2002). “A Crisis of Institutionalization: The Collapse of the UCD in Spain", in GUNTHER, R., LINZ, J. J. e MONTERO, J. R. Political Parties: Old Concepts and New Challenges, Oxford University Press, edição digital.

GUNTHER, Richard e MONTERO, José Ramón (2002). "Reviewing and Reassessing Parties", in GUNTHER, R., LINZ, J. J. e MONTERO, J. R. Political Parties: Old Concepts and New Challenges, Oxford University Press, edição digital.

HIPÓLITO, Lucia (1985). PSD, de raposas e reformistas, São Paulo, Paz e Terra.

KATZ, Richard e MAIR, Peter (1995). "Changing Models of Party Organization and Party Democracy: The Emergence of the Cartel Party", Party Politics, 1: 5-28.

KATZ, R. e MAIR, P. (1996). "Cadre, Catch-All or Cartel? A Rejoinder", Party Politics, 2: 52534.

KATZ, R. e MAIR, P. (1997). "Party Organization, Party Democracy and the Emergence of the Cartel Party", in P. Mair, Party Systems Change: Aproaches and Interpretations. Oxford University Press.

KATZ, Richard e MAIR, Peter (1993). "The Evolution of Party Organizations in Europe: The Three Faces of Party Organization", in W. Crotty (ed.) Political Parties in a Changing Age, edição especial da American Review of Politics, 14: 593-617. 
KATZ, Richard e MAIR, Peter (2002). "The Ascendancy of the Party in Public Office: Party Organizational Change in Twentieth-Century Democracies", in GUNTHER, R., LINZ, J. J. e MONTERO, J. R. Political Parties: Old Concepts and New Challenges, Oxford University Press, edição digital.

KATZ, Richard e MAIR, Peter (2009). "The Cartel Party Thesis: A Restatement", Perspectives on Politics, dezembro 2009, vol. 7, no. 4.

KI NZO, Maria D’Alva G. (1988). Oposição e autoritarismo - gênese e trajetória do MDB, 19661979. São Paulo: Vértice/Idesp, 1988.

KINZO, Maria D’Alva (2005) “Os Partidos no Eleitorado: Percepções Públicas e Laços Partidários no Brasil", Revista Brasileira de Ciências Sócias, vol 20, no. 57.

KINZO, Maria D'Alva e CARREIRÃO, Yan de Souza (2004) "Partidos Políticos, Preferência Partidária e Decisão Eleitoral no Brasil (1989/2002)". Dados, vol 47. no. 1, pp 131-168.

KIRCHHEIMER, O. (1966). "The Transformation of Western European Party Systems", in J. La Palombara and M. Weiner (eds), Political Parties and Political Development, Princeton: Princeton University Press.

KOOLE, R. (1994). "The Vulnerability of the Modern Cadre Party in the Netherlands", in R. S. Katz and P. Mair (eds), How Parties Organize: Change and Adaptation in Party Organization in Western Democracies. Londres: Sage.

KOOLE, R. (1996). "Cadre, Catch-All or Cartel? A Comment on the Notion of the Cartel Party", Party Politics, 2: 507-34.

KWAK, Jin Young (2003). "The Party-State Liasion in Korea: Searching for Evidence of the Cartelized System", Asian Perspective, vol. 27. no. 1, 2003, pp 109-135.

LAMOUNIER, Bolívar (1985). "Formação de um Pensamento Político Autoritário na Primeira República. Uma Interpretação", in B. Fausto (org.), História Geral da Civilização Brasileira - T. III. O Brasil Republicano (3a ed.). São Paulo, Difel, vol. 2.

LAMOUNIER, Bolívar (1992). "Estrutura institucional e governabilidade na década de 90". In Reis Velloso, J oão Paulo do. org, O Brasil e as reformas políticas. Rio de Janeiro, José Olympio. LAMOUNIER, Bolívar (1994). "A democracia brasileira dos anos 80 aos 90: a síndrome da paralisia hiperativa". In: Reis Velloso, João Paulo do. org. Governabilidade, sistema político e violência urbana. Rio de Janeiro, J osé Olympio.

LAMOUNIER, Bolívar (2005). Da Independência a Lula: dois séculos de política brasileira. São Paulo, Augurium Editora.

LAMOUNIER, Bolívar e MENEGUELLO, Rachel (1986) Partidos Políticos e Consolidação Democrática, Brasiliense.

LAVAlLE, A. G.; HOUTZAGER, P.; CASTELLO, G. (2006). “Democracia, Pluralização da Representação e Sociedade Civil". Lua Nova 67: 49-104.

LAVAREDA, Antônio (1985) "O Partido da Frente Liberal: o dissenso dos governadores pedessistas nordestinos e a busca de uma nova imagem", in FALCÃO e SÁ (orgs.), Nordeste: Eleições, Recife: Ed.Massangana, pp. 39-60. 
LAVAREDA, Antônio (1991). A Democracia nas Urnas, Rio de Janeiro, IUPERJ/Rio Fundo.

LEAL, Paulo Roberto Figueira (2005). O PT e o dilema da representação política: os deputados federais são representantes de quem?. Editora FGV.

LIMONGI, Fernando (1999). "Institucionalização política”. In Miceli, Sérgio org. O que ler na Ciência Social brasileira (1970-1995), Anpocs, Ed. Sumaré.

LIMONGI, Fernando (2002). Debate institucional e democracia no Brasil: O problema do sistema partidário. In: Perissinoto, Renato e Mario Fuks. (Org.). Democracia: Teoria e Prática. Rio de Janeiro: Relume Dumará, p. 55-72.

LIMONGI, Fernando (2006). "A democracia no Brasil". Novos Estudos Cebrap, no. 76, novembro, 17-41.

LINZ, Juan J. (2002). "Parties in Contemporary Democracies: Problems and Paradoxes", in GUNTHER, R., LINZ, J. J. e MONTERO, J. R. Political Parties: Old Concepts and New Challenges, Oxford University Press, edição digital.

LIPPI, Lúcia (1973). O Partido Social Democrático. Dissertação de Mestrado. Rio de Janeiro, IUPERJ .

MAI NWARING, Scott P. (1999), Sistemas Partidários em Novas Democracias: o Caso do Brasil. Editora FGV.

MAI NWARING, Scott P; MENEGUELLO, Rachel e POWER, Timoty (2000). Partidos conservadores no Brasil contemporâneo. São Paulo, Paz e Terra.

MAIR, Peter (1994). "Party Organizations; from civil society to the State". In Mair, P and Katz, R. S. (Eds.) How Parties Organize - change and adaptation in party organizations in westerns democracies. London, SAGE Publications.

MAIR, Peter (1997). Party Systems Change: Approaches and Interpretations. Oxford University Press.

MAIR, Peter (2009). "Representative versus Responsible Government", MPIfG Working Paper 09/08.

MANIN, Bernard (1997) The Principles of Representative Government. Cambridge, Cambridge University Press.

MARQUES, Jales e FLEISCHER, David (1996), De facção a partido: o Partido da Social Democracia Brasileira (1987/1995). Brasília, Konrad Adenauer/Stiftung.

MCI (2004). PFL: Imagem e Reposicionamento. Mimeo.

MELO, Carlos Ranulfo (2004). Retirando as Cadeiras do Lugar: Migração Partidária na Câmara dos Deputados (1985/2002). Belo Horizonte: Editora UFMG.

MENEGUELLO, Rachel (1998). Partidos e governos no Brasil contemporâneo, (1985-1997). Paz e Terra.

MICHELS, R. (1962[1911]). Political Parties: A Sociological Study of the Organizational Tendencies in Modern Democracies. New York: Free Press. 
NICOLAU, Jairo (2000), “Disciplina partidária e base parlamentar na Câmara dos Deputados no primeiro governo Fernando Henrique Cardoso (1995-1998)", Dados-Revista de Ciências Sociais, Rio de Janeiro, Vol. 43, no. 4.

NICOLAU, Jairo (2010). Dados Eleitorais do Brasil (1986-06), in http://jaironicolau.iesp.uerj.br/banco2004.html .

NI COLAU, Jairo (1996). Multipartidarismo e Democracia. Editora Fundação Getúlio Vargas. OSTROGORSKI, M. I. (1964[1902]). Democracy and the Organization of the Political Parties. London: Macmillan.

PAIVA, Denise; BRAGA, Maria do Socorro S. e PIMENTEL, Jairo Tadeu Pires (2007). "Eleitorado e partidos políticos no Brasil". Opinião Pública, Campinas, vol. 13, no. 2, nov, 2007, pp 388 a 408.

PANEBIANCO, A. (1988). Political Parties: Organization and Power. Cambridge: Cambridge University Press.

PERES, Paulo Sérgio (2004). Sistema Partidário e Dinâmica Democrática no Brasil. Tese de Doutorado, FFLCH-USP, Departamento de Ciência Política, mimeo.

PFL (2007), "Refundação do Partido da Frente Liberal”, mimeo.

POWER, Timothy J. (2000). The Political Right in Postauthoritarian Brazil - Elites, Institutions, and Democratization. The Pennsylvania State University Press, University Park, Pennsylvania.

QUEIROZ, Saulo (2009). “Trinta anos”, mimeo.

REIS, Fábio Wanderley (1988) "Partidos, ideologia e consolidação democrática". In Reis, Fábio Wanderley \& O'Donnel, Guilhermo. orgs. A democracia no Brasil. Dilemas e Perspectivas. São Paulo: Vértice, pp. 296-326.

REIS, Fábio Wanderley (1995) "Governabilidade, instituições e partidos". Novos Estudos Cebrap, 41, pp 40-59.

REIS, Fábio Wanderley (1999). "Institucionalização política (comentário crítico)”. In Miceli, Sérgio (org). O que ler na Ciência Social brasileira (1970-1995), Anpocs, Ed. Sumaré.

REIS, Fábio Wanderley (2000) "Regiões, Classes e Ideologia no Processo Eleitoral”, in F. W. Reis, Mercado e Utopia, São Paulo, Edusp, pp 281-325.

RICCI, Paolo (2003). "O Conteúdo da Produção Legislativa Brasileira: Leis Nacionais ou Políticas Paroquiais". DADOS - Revista de Ciências Sociais, Rio de Janeiro, Vol. 46, no. 4, PP 699 a 734.

ROMA, Celso (2002), "A institucionalização do PSDB entre 1988 e 1999". Revista Brasileira de Ciências Sociais, vol 17, no. 49, pp 71 a 92.

SAMPAIO, Regina (1982). Ademar de Barros e o PSP, São Paulo Global Editora.

SAMUELS, David (1998). "The Gubernatorial Coattails Effect: federalism and congressional elections in Brazil". The Journal of Politics, v. 62, n. 1, p. 240-253, feb.

SANTOS, Fabiano dos (1997). "Patronagem e poder de agenda na política brasileira", Dados, Rio de Janeiro, vol. 40, n. 4. 
SARTORI, Giovanni (1982). Partidos e Sistemas Partidários. Brasília: Zahar Editores.

SCARROW, Susan (2006). "Party subsidies and the freezing of party competition: Do cartels work", West European Politics 29 (4): 619-39.

SCHATTSCHNEIDER, E. E. (1942). Party Government. New York: Holt, Rinehart \& Winston.

SCHWARTZMAN, Simon (1982). Bases do autoritarismo brasileiro. Editora Campus.

SINGER, André (2010). "Raízes Sociais e I deológicas do Lulismo", Novos Estudos 85, novembro 2009.

SOARES, Gláucio A. D. (1971). “El Sistema Electoral y la Representación de los Grupos Sociales em Brasil, 1945-1962", Revista Latinoamericana de Ciência Política, vol. II, no. 1.

SOARES, Gláucio A. D. (1974). Sociedade e Política do Brasil, São Paulo, DIFEL.

SOUZA, Maria do Carmo C. (1976). Estados e Partidos Políticos no Brasil. São Paulo: Alfa Ômega.

STROM. K. (1990). Minority Government and Majority Rule. Cambridge: Cambridge University Press.

TAROUCO, Gabriela da Silva (1999). O Partido da Frente Liberal: Trajetória e Papel no Sistema Político. Dissertação de Mestrado, Unicamp.

TAROUCO, Gabriela da Silva (2002). "Fatores do desenvolvimento do Partido da Frente Liberal", in: Céli Regina Jardim Pinto; André Marenco dos Santos. (Org.). Partidos no Cone Sul: novos ângulos de pesquisa. Rio de Janeiro: Fundação Konrad-Adenauer-Stiftung, 2002, v. 1, p. 133-162.

URBINATI, N. (2006). Representative Democracy: Principles and Genealogy. Chicago: Chicago University Press.

URBINATI, N. e WARREN, M. E. (2008). "The Concept of Representation in Contemporary Democratic Theory". Annual Review of Political Science 11: 387-412.

VEIGA, Luciana Fernandes (2007), “Os partidos brasileiros na perspectiva dos eleitores: mudanças e continuidade na identificação partidária e na avaliação das principais legendas após 2002". Opinião Pública, Campinas, vol. 13, no. 2, nov, 2007, pp 340 a 365.

WEBER, Max (1978[1922]. Economy and Society. California: University of California Press. WOLINETZ, Steven B. (2002). "Beyond the Catch-All Party: Approaches to the Study of Parties and Party Organization in Contemporary Democracies", in GUNTHER, R., LINZ, J. J. e MONTERO, J. R. Political Parties: Old Concepts and New Challenges, Oxford University Press, edição digital.

WOOLDRIDGE, J effrey M. (2003). Introdutory Econometrics: A Modern Approach, Thomson South-Western.

ZUCCO, Cesar (2008). “The President's 'New' Constituency: Lula and the Pragmatic Vote in Brazil's 2006 Presidential Elections". J ournal of Latin American Studies, v. 40, p. 22, 2008.

ZUCCO, Cesar (2010). “Poor Voters vs. Poor Places: Persisting patterns in presidential elections in Brazil", mimeo. http://fas-polisci.rutgers.edu/zucco/. 


\section{Apêndice 1}

Documentos produzidos pelo partido e utilizados como material de pesquisa nesta dissertação:

$\checkmark \quad$ "Refundação do Partido da Frente Liberal” - abril/2005.

$\checkmark \quad$ “Código de Ética do DEM” - 2007.

$\checkmark \quad$ "Ata da Convenção Nacional do PFL" que referendou a troca de nome do partido para Democratas - 28/03/2007.

$\checkmark \quad$ “Estatuto do DEM" - 12/12/2007.

\section{Textos programáticos e utilizados nesta dissertação}

$\checkmark \quad$ "A refundação do PFL" - dezembro/2005.

$\checkmark \quad$ "A bem sucedida privatização brasileira" - Antonio Paim, 2007.

$\checkmark \quad$ “Democratas, 25 palavras para vencer", 2007.

$\checkmark \quad$ “Cadernos Liberais" - várias edições, 1998-2007.

$\checkmark \quad$ Revista Liberdade e Cidadania - várias edições, set/2008-dez/2010. 


\section{Apêndice 2}

Ranking do I DH dos estados brasileiros em 2005

\begin{tabular}{|c|c|c|}
\hline 1 & Distrito Federal & 0,874 \\
\hline 2 & Santa Catarina & 0,840 \\
\hline 3 & São Paulo & 0,833 \\
\hline 4 & Rio de Janeiro & 0,832 \\
\hline 5 & Rio Grande do Sul & 0,832 \\
\hline 6 & Paraná & 0,820 \\
\hline 7 & Espírito Santo & 0,802 \\
\hline 8 & Mato Grosso do Sul & 0,802 \\
\hline 9 & Goiás & 0,800 \\
\hline 10 & Minas Gerais & 0,800 \\
\hline 11 & Mato Grosso & 0,796 \\
\hline 12 & Amapá & 0,780 \\
\hline 13 & Amazonas & 0,780 \\
\hline 14 & Rondônia & 0,776 \\
\hline 15 & Tocantins & 0,756 \\
\hline 16 & Pará & 0,755 \\
\hline 17 & Acre & 0,751 \\
\hline 18 & Roraima & 0,750 \\
\hline 19 & Bahia & 0,742 \\
\hline 20 & Sergipe & 0,742 \\
\hline 21 & Rio Grande do Norte & 0,738 \\
\hline 22 & Ceará & 0,723 \\
\hline 23 & Pernambuco & 0,718 \\
\hline 24 & Paraíba & 0,718 \\
\hline 25 & Piauí & 0,703 \\
\hline 26 & Maranhão & 0,683 \\
\hline 27 & Alagoas & 0,677 \\
\hline
\end{tabular}

Fonte: PNUD Brasil 


\section{Apêndice 3}

Relação entre transferências totais da União e receita total dos estados - \% (calculada com base nos valores correntes de 2009)

\begin{tabular}{|l|c|}
\hline Amapá & 65,4 \\
\hline Roraima & 55,3 \\
\hline Maranhão & 48,9 \\
\hline Tocantins & 48,4 \\
\hline Acre & 46,5 \\
\hline Sergipe & 45,3 \\
\hline Alagoas & 43,8 \\
\hline Piauí & 43,7 \\
\hline Paraíba & 40,9 \\
\hline Rio Grande do Norte & 36,4 \\
\hline Rondônia & 36,0 \\
\hline Pará & 33,8 \\
\hline Bahia & 27,8 \\
\hline Ceará & 26,5 \\
\hline Pernambuco & 26,0 \\
\hline Amazonas & 19,1 \\
\hline Mato Grosso & 18,3 \\
\hline Espírito Santo & 15,6 \\
\hline Goiás & 15,5 \\
\hline Paraná & 15,2 \\
\hline Santa Catarina & 12,5 \\
\hline Mato Grosso do Sul & 12,3 \\
\hline Minas Gerais & 11,7 \\
\hline Rio Grande do Sul & 9,8 \\
\hline Distrito Federal & 9,7 \\
\hline São Paulo & 7,7 \\
\hline Rio de Janeiro & 5,9 \\
\hline Todos os estados & 16,5 \\
\hline
\end{tabular}

Fonte: Secretaria do Tesouro Nacional. 


\section{Apêndice 4}

\section{Lista dos Partidos}

\begin{tabular}{|l|l|}
\hline ARENA & Aliança Renovadora Nacional \\
\hline DEM & Democratas \\
\hline MDB & Movimento Democrático Brasileiro \\
\hline PC do B & Partido Comunista do Brasil \\
\hline PDS & Partido Democrático Social \\
\hline PDT & Partido Democrático Trabalhista \\
\hline PFL & Partido da Frente Liberal \\
\hline PL & Partido Liberal \\
\hline PMDB & Partido do Movimento Democrático Brasileiro \\
\hline PMN & Partido da Mobilização Nacional \\
\hline PP & Partido Popular \\
\hline PPS & Partido Popular Socialista \\
\hline PR & Partido da República \\
\hline PSB & Partido Socialista Brasileiro \\
\hline PSD & Partido Social Democrático \\
\hline PSDB & Partido da Social Democracia Brasileira \\
\hline PSL & Partido Social Liberal \\
\hline PSOL & Partido Socialismo e Liberdade \\
\hline PT & Partido dos Trabalhadores \\
\hline PTB & União Democrática Nacional \\
\hline UDN & \\
\hline
\end{tabular}

